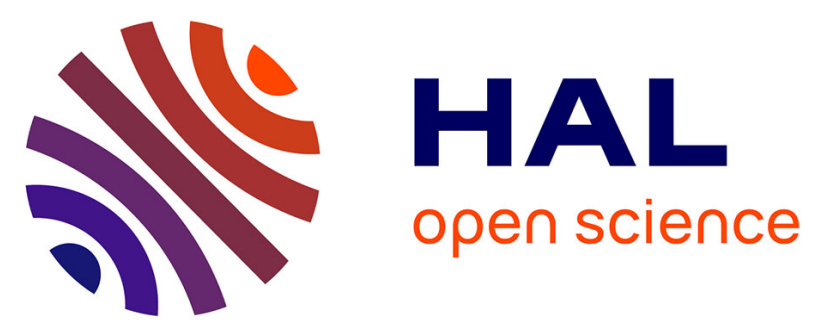

\title{
Positron Emission Tomography Imaging of Neurotensin Receptor-Positive Tumors with 68 Ga-Labeled Antagonists: The Chelate Makes the Difference Again
}

Emma Renard, Mathieu Moreau, Pierre-Simon Bellaye, Mélanie Guillemin, Bertrand Collin, Aurélie Prignon, Franck Denat, Victor Goncalves

\section{To cite this version:}

Emma Renard, Mathieu Moreau, Pierre-Simon Bellaye, Mélanie Guillemin, Bertrand Collin, et al.. Positron Emission Tomography Imaging of Neurotensin Receptor-Positive Tumors with 68 Ga-Labeled Antagonists: The Chelate Makes the Difference Again. Journal of Medicinal Chemistry, 2021, 64 (12), pp.8564-8578. 10.1021/acs.jmedchem.1c00523 . hal-03470823

\section{HAL Id: hal-03470823 \\ https://hal.science/hal-03470823}

Submitted on 8 Dec 2021

HAL is a multi-disciplinary open access archive for the deposit and dissemination of scientific research documents, whether they are published or not. The documents may come from teaching and research institutions in France or abroad, or from public or private research centers.
L'archive ouverte pluridisciplinaire HAL, est destinée au dépôt et à la diffusion de documents scientifiques de niveau recherche, publiés ou non, émanant des établissements d'enseignement et de recherche français ou étrangers, des laboratoires publics ou privés. 


\title{
PET Imaging of Neurotensin Receptor-Positive Tumors with ${ }^{68} \mathrm{Ga}-\mathrm{La}-$ beled Antagonists: « the Chelate Makes Again the Difference »
}

\author{
Emma Renard, ${ }^{\dagger}$ Mathieu Moreau, ${ }^{\dagger}$ Pierre-Simon Bellaye, ${ }^{\ddagger}$ Mélanie Guillemin,$\risingdotseq$ Bertrand Col- \\ lin,$*$ Aurélie Prignon, $\$$ Franck Denat, ${ }^{\dagger}$ Victor Goncalves ${ }^{*}, \dagger$ \\ †Institut de Chimie Moléculaire de l’Université de Bourgogne, ICMUB UMR CNRS 6302, Université Bourgogne \\ Franche-Comté, 21000 Dijon, France \\ ‡Georges-François LECLERC Cancer Center - UNICANCER, 21000 Dijon, France \\ §Sorbonne Université, UMS28 Laboratoire d'Imagerie Moléculaire Positonique (LIMP), 75020 Paris, France \\ KEYWORDS: Neurotensin; antagonist; positron emission tomography; gallium-68
}

\begin{abstract}
Neurotensin receptor $1\left(\mathrm{NTS}_{1}\right)$ is involved in the development and progression of numerous cancers, which makes it an interesting target for the development of diagnostic and therapeutic agents. A small molecule NTS ${ }_{1}$ antagonist, named [177Lu]Lu-IPN01087, is currently evaluated in phase I/II clinical trials for the targeted therapy of neurotensin receptor-positive cancers. In this study, we synthesized seven compounds based on the structure of NTS ${ }_{1}$ antagonists, bearing different chelating agents, and radiolabeled them with gallium- 68 for PET imaging. These compounds were evaluated in vitro and in vivo in mice bearing a HT-29 xenograft. The compound [ ${ }^{68} \mathrm{Ga}$ ]Ga-bisNODAGA-16 showed a promising biodistribution profile with mainly signal in tumor $(4.917 \pm 0.776 \% \mathrm{ID} / \mathrm{g}$, $2 \mathrm{~h}$ post-injection). Its rapid clearance from healthy tissues led to high tumor-to-organ ratios, resulting in highly contrasted PET images. These results were confirmed on subcutaneous xenografts of AsPC-1 tumor cells, a model of NTS 1 -positive human pancreatic adenocarcinoma.
\end{abstract}

\section{INTRODUCTION}

Molecular imaging is a non-invasive technique that participates to the rapid and accurate diagnosis of many cancers. It relies on the administration of an imaging probe capable of binding specifically to a biomarker of the disease. The localization of this probe is then classically achieved by positron emission tomography (PET) or single photon emission computed tomography (SPECT) in oncology. ${ }^{1}$

An interesting target involved in the development and progression of numerous cancers is the neurotensin receptor 1 (NTS $)_{1}{ }^{2,3}$ This G-protein coupled receptor is overexpressed in different cancers such as pancreatic ductal adenocarcinoma, ${ }^{4}$ prostate cancer, ${ }^{5}$ Ewing's sarcoma, ${ }^{6}$ colorectal cancer, ${ }^{7}$ breast cancer ${ }^{8}$ and small cell lung cancer, but not present in healthy tissues. ${ }^{9}$ The endogenous ligand of this receptor is a tridecapeptide called neurotensin (NT). ${ }^{10}$

These last years, neurotensin and its receptors have been the subject of numerous studies. Most of them deal with the design of NTS 1 agonists. Those agonists are generally peptide analogs of neurotensin, which have been labeled with radiometals or fluorophores for nuclear imaging, radiotherapy, or fluorescence imaging. ${ }^{11-14}$ Despite their good affinity for NTS ${ }_{1}$ (in the nanomolar range) and interesting biodistribution properties, these compounds often present limited metabolic stability, even after chemical optimization. ${ }^{15,16}$

In the early 90s, Sanofi-Recherche discovered a nonpeptidic antagonist of NTS 1 named SR45398 (Figure 1). ${ }^{17,18}$ After few years of optimization, they identified SR142948A, a drug candidate with nanomolar affinity and potency for neurotensin receptors. ${ }^{19,20}$ Starting from the structure of SR142948A, a few radiotracers were developed for the diagnosis or therapy of neurotensin receptor-positive cancers. Such tracers present several advantages: in the absence of activation of receptor's signaling pathways, they produce no pharmacological effect; they often show better metabolic stability than peptides; ${ }^{21,22}$ and, their small 
size allows for a rapid biodistribution, with fast renal clearance.
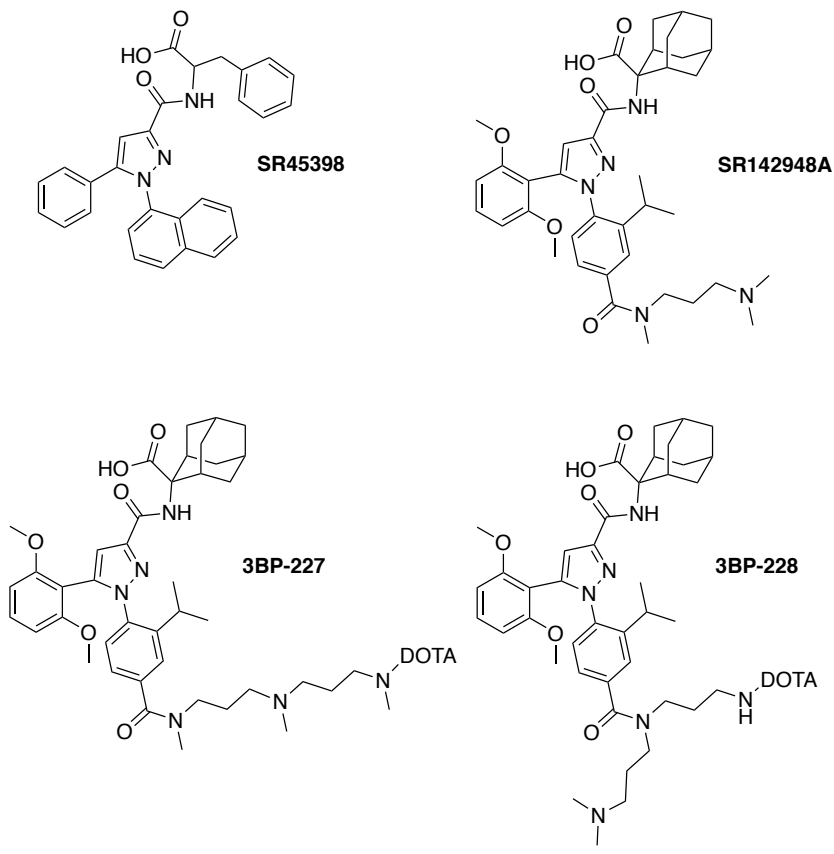

Figure 1. Chemical structures of SR45398, SR142948A, 3BP227 and 3BP-228. DOTA stands for 1,4,7,10-tetraazacyclododecane-1,4,7,10-tetraacetic acid.

Furthermore, it has been shown that agonists and antagonists may not necessarily recognize the same conformational states of their receptors. ${ }^{23-25}$ This phenomenon has also been observed with neurotensin receptors, by Betancur et al., who showed that the number of receptors labeled by the antagonist [ $\left.{ }^{3} \mathrm{H}\right] \mathrm{SR} 142948 \mathrm{~A}$ on rat brain membranes was $80 \%$ greater than that detected when using the agonist $\left[{ }^{3} \mathrm{H}\right]$ neurotensin. ${ }^{20}$

In 2013, Lang et al. synthesized an analog of SR142948A and coupled it to 2-deoxy-2-[18F]fluoroglucosylazide to create a PET imaging tracer. ${ }^{21}$ This compound showed an excellent affinity for $\mathrm{NTS}_{1}(0.98 \mathrm{nM})$. However, despite a fairly good uptake in tumor tissues, a significant accumulation was observed in other organs, particularly the liver. In 2016, Schulz et al. introduced a polyazamacrocyclic metal-chelating agent (DOTA) on different analogs of SR142948A and radiolabeled them with indium-111, a radionuclide suitable for SPECT imaging. ${ }^{26}$ Their compounds [111In]In-3BP-227 and [111In]In-3BP-228 (Figure 1) showed good affinity for neurotensin receptor 1 and high and specific tumor uptake in vivo. Because of its prolonged retention in the target tissue at late time-points (24 $\mathrm{h}$ after injection), 3BP-227 was considered as a good candidate for the radiotherapy of cancer. In 2017, Schulz et al., evaluated 3BP-227 (now IPN01087) for the ${ }^{177} \mathrm{Lu}$-radiotherapy of colon carcinoma in a preclinical study. Their promising results paved the way for a radiotherapy trial, 22 which was initiated in 2018 by Baum and coll. on patients with metastatic or locally advanced cancers expressing NTS ${ }_{1}{ }^{27}$ Preliminary results provided clinical evidence of the feasibility of treatment of ductal pancreatic adenocarcinoma with the ${ }^{177} \mathrm{Lu}_{\text {-labeled NTS }}$ antagonist 3BP-227.28

The availability of a PET companion diagnostic agent would greatly facilitate the selection of patients eligible for $\mathrm{NTS}_{1}$-targeted radiotherapy. ${ }^{29}$ In this study, we sought to assess the influence of the chelator on the biodistribution of neurotensin receptor antagonists. A variety of chelating agents, suitable for the complexation of ${ }^{68} \mathrm{Ga}$, was coupled to an analog of SR142948A. The resulting tracers were then evaluated in vitro and tested in vivo on mice xenografted with an HT-29 model of colorectal cancer or an AsPC-1 model of pancreatic cancer.

\section{RESULTS AND DISCUSSION}

Design and synthesis. A series of seven imaging agents, antagonists of neurotensin receptors, were synthesized. In light of the study by Schulz et al., we chose to build our compounds based on the structure of the compound 3BP$228 .{ }^{26}$ This compound differs from 3BP-227 in its amine arm. Indeed, 3BP-227 carries a linear amine arm, whereas 3BP-228 has a branched amine arm (Figure 1). Tumor uptakes of [ $\left.{ }^{111} \mathrm{In}\right] \mathrm{In}-3 \mathrm{BP}-227$ and [111 In]In-3BP-228 were similar at 3, 6 and $12 \mathrm{~h}$ post-injection, but tumor-to-normal tissue ratios were generally higher for [ $\left.{ }^{111} \mathrm{In}\right] \mathrm{In}-3 \mathrm{BP}-228$ at the earliest time-point ( $3 \mathrm{~h}$ p.i.), although not statistically different. Since our objective was to design a PET tracer, showing rapid clearance from healthy tissues, in particular from the liver and gastrointestinal tract to facilitate the detection of the primary tumor and potential metastases, we felt that it was more interesting to select 3BP-228's scaffold. Nonetheless, the compound 3BP-227 was also synthesized and used as a reference in this study.

Gallium-68 was chosen as the radiometal. Indeed, this positron-emitting radioisotope has a short half-life of 67.7 min which is perfectly suited to the rapid pharmacokinetics of small molecules and reduces patient exposure to ionizing radiation compared to other radiometals with longer half-lives such as copper-64 or zirconium-89. In addition, ${ }^{68} \mathrm{Ga}$ has a relatively low cost and is readily available thanks to ${ }^{68} \mathrm{Ge} /{ }^{68} \mathrm{Ga}$ generators. ${ }^{30}$ Alternatively, it can be produced in cyclotrons via the ${ }^{68} \mathrm{Zn}(\mathrm{p}, \mathrm{n})^{68} \mathrm{Ga}$ reaction, which further increases the availability of this radiometal. ${ }^{31}$

Several chelating agents suitable for ${ }^{68} \mathrm{Ga}$ complexation are available. ${ }^{32-34}$ Among them, we first chose to evaluate NOTA, (R)-NODAGA, DOTA, DOTAGA and THP. All these chelators are able to form stable complexes. Due to their differences in charge and $\log D$, we hypothesized that the presence of these chelates could significantly modify the pharmacokinetics of the tracers. ${ }^{35-40}$ In addition, we have also chosen to introduce two (R)-NODAGA 
or DOTAGA chelators on a same molecule in order to increase clearance from blood and improve tumor-to-background ratios. This approach was inspired by the work of Roxin et al., who showed that the introduction of a metalfree DOTA on a ${ }^{18} \mathrm{~F}$-radiotracer could improve tumor uptake and increase renal excretion..$^{41}$

The compounds were prepared by multi-step synthesis from four synthons (Scheme 1). The first synthon (A), 3isopropyl-4-hydrazinobenzoic acid hydrochloride, was synthesized in six steps starting from 2-isopropylaniline with a yield of $9 \% .{ }^{42}$ The second synthon (B), ethyl-4-(2,6dimethoxyphenyl)-4-hydroxy-2-oxobut-3-enoate was prepared, starting from diethyl oxalate and 2,6-dimethoxyacetophenone, with a yield of $73 \% .{ }^{43}$ The amine arm (synthon C) was obtained in three steps with a yield of $50 \% .{ }^{44}$ The fourth synthon (D), tert-butyl-2-aminoadamantane-2-carboxylate, was synthesized in four steps starting from 2-adamantanone with a yield of $23 \%$. ${ }^{45,46}$ The linear amine arm (synthon E), for the reference compound 3BP-227, was prepared in one step in $80 \%$ yield. Four steps were then required to obtain the precursor 16, ready for conjugation with the different chelating agents. ${ }^{42,47}$ Finally, the introduction of the chelators was achieved in one or two steps, in yields ranging from 15 to $65 \%$.

Stability. In order to evaluate the stability of these molecules against enzymatic degradation, each compound was metalated with non-radioactive gallium and incubated in mouse serum at $37{ }^{\circ} \mathrm{C}$. RP-HPLC-MS analyses were performed at different time-points ( $0 \mathrm{~min}, 30 \mathrm{~min}, 1$ $\mathrm{h}, 2 \mathrm{~h}, 4 \mathrm{~h}$ and $24 \mathrm{~h})$. Interestingly, NOTA/NODAGA/THP-based compounds proved to be stable in these assay conditions (>99\% intact product after $4 \mathrm{~h}$ ) whereas DOTA/DOTAGA-based compounds showed some degradation (ca. 80\% intact product after 4 h) (Table 1, Table S1). The main degradation corresponded to the loss of gallium as evidenced by mass spectrometry. This shows the importance of the cavity size on the thermodynamic stability of ${ }^{68} \mathrm{Ga}$-complexes (the expansion of the macrocyclic ring results in a decrease in the complexation constant: $\log \mathrm{K}_{\text {Ga-NOTA }}=31.0$ vs $\log \mathrm{K}_{\text {Ga-DOTA }}=$ 26.1). ${ }^{48}$ After $24 \mathrm{~h}$, some unidentified degradation products (mass loss of 27) were also observed. Although these in vitro data do not necessarily reflect the metabolic stability of the compounds in vivo, they do confirm the good stability of small molecules relative to peptides. For comparison, only $55 \%$ of the natural neurotensin was found intact after $4 \mathrm{~h}$ of incubation in the same assay conditions (Table S1).

In vitro Binding Affinity. The affinity for $\mathrm{NTS}_{1}$ of the seven natGa-metalated compounds and the reference ${ }^{n a t} \mathrm{Ga}-3 \mathrm{BP}-227$ was determined in a competition experiment on $\mathrm{CHO}$ cells overexpressing $\mathrm{NTS}_{1}$ receptor. [ $\left.{ }^{125} \mathrm{I}\right] \mathrm{I}-$
Tyr ${ }^{3}$-neurotensin $\left(0.05 \mathrm{nM} ; K_{\mathrm{d}}=0.22 \mathrm{nM}\right)$ was used as ligand. ${ }^{49}$ The $K_{\mathrm{i}}$ values were in the nanomolar range for most of the compounds (Table 1, Figure S48). The compounds with a single chelator showed the best affinities with $K_{\mathrm{i}}$ values between 0.7 and $3.6 \mathrm{nM}$, similar to the reference ${ }^{n a t}$ Ga-3BP-227 (0.55 nM). According to these results, it seems that the presence of a positive charge favors bind-

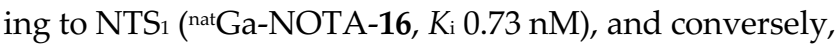
an increase in the number of negative charges has a detrimental effect on affinity ( ${ }^{n a t} G a-D O T A G A-16, K_{\mathrm{i}} 3.59 \mathrm{nM}$ ). In comparison, the compounds with two chelating agents showed a significant decrease in affinity ( $K_{\mathrm{i}}$ of $9 \mathrm{nM}$ and

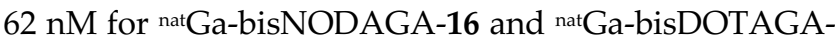
16 respectively).

Radiolabeling and Partition Coefficients. All the compounds were radiolabeled with ${ }^{68} \mathrm{Ga}$, using $\left[{ }^{68} \mathrm{Ga}\right] \mathrm{GaCl}_{3}$ obtained after elution of a generator with an $0.1 \mathrm{M} \mathrm{HCl}$ solution. A solution of sodium acetate buffer $(0.5 \mathrm{M}, \mathrm{pH}$ 5.56) was added to the compounds in order to reach a final $\mathrm{pH}$ of 3.5. Ten percent of ethanol were also introduced to limit radiolysis. The radiolabeling of NOTA, NODAGA and THP-based compounds was performed at $37^{\circ} \mathrm{C}$ for five minutes whereas ten minutes at $95^{\circ} \mathrm{C}$ were required to radiolabel DOTA and DOTAGA-based compounds. Each tracer was purified on a $\mathrm{C}_{18}$ Sep-Pack column to obtain the desired compound with a radiochemical purity $>94 \%$, as determined by radio-HPLC. The radiochemical yields ranged from $35 \%$ to $80 \%$ and molar activities from 8.8 to $17.8 \mathrm{MBq} / \mathrm{nmol}$ at the end of radiolabeling. Partition coefficients $(\log \mathrm{D})$ were determined by the shake-flask method in octanol and PBS at $\mathrm{pH} 7.4 .^{50}$ All compounds were found to be hydrophilic. As expected, compounds with two chelating agents are more hydrophilic with $\log \mathrm{D}$ values of about -3.5 while values ranging from -1.7 to -2.6 are obtained for compounds with only one chelating agent. The compound [ $\left.{ }^{68} \mathrm{Ga}\right] \mathrm{Ga}-\mathrm{THP}-16$ is the least hydrophilic of all with a $\log \mathrm{D}$ of -1.2 (Table 1 ) 
Scheme 1. Synthesis of $\mathrm{NTS}_{1}$ antagonistsa
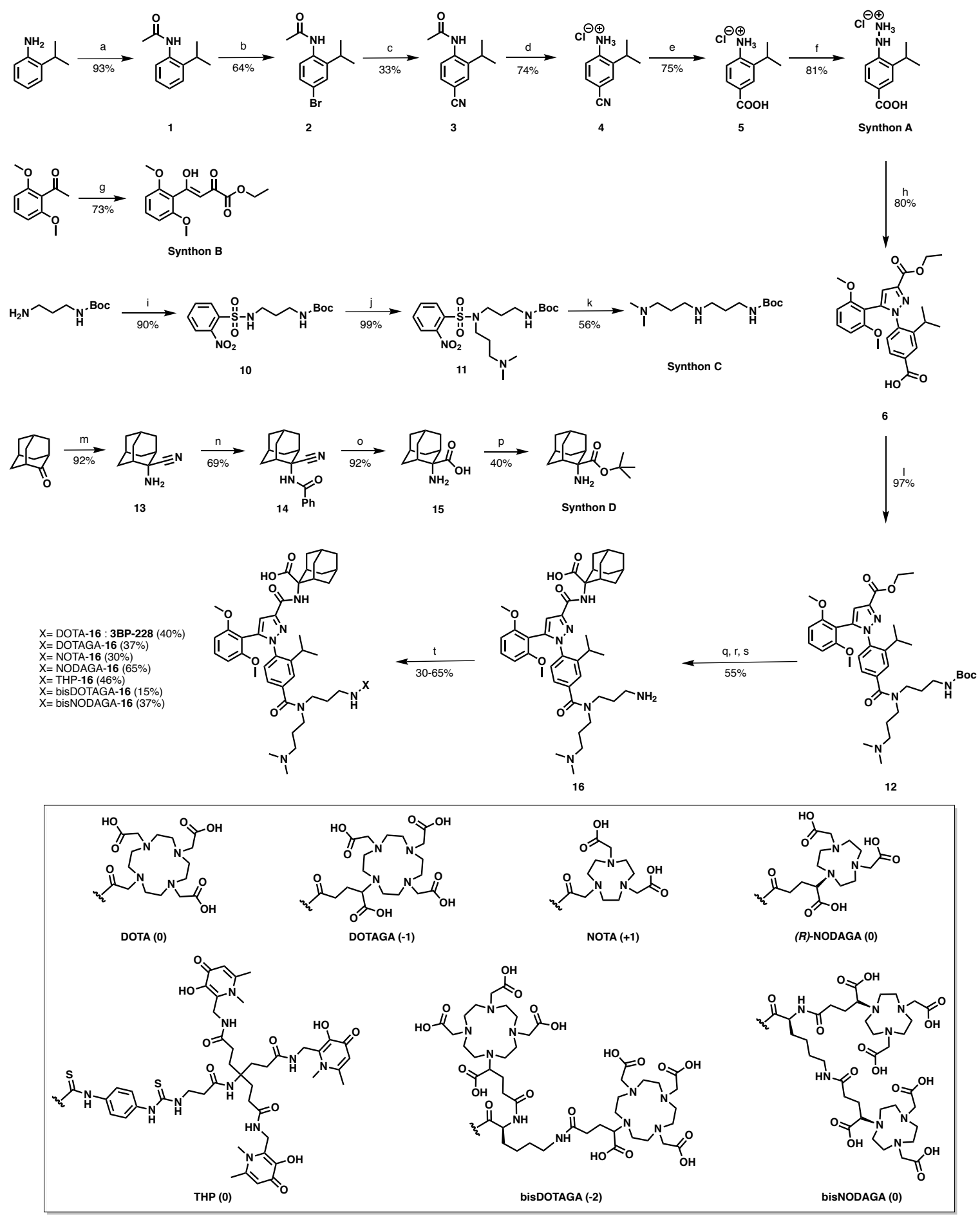

aReagents and conditions: (a) Ac2 $\mathrm{O}$, toluene, $0^{\circ} \mathrm{C}$ to RT, 1 h; (b) NBS, DMF, RT, o.n.; (c) CuCN, $\mathrm{H}_{2} \mathrm{O} / \mathrm{DMF}$, reflux, o.n.; (d) $1 \mathrm{M} \mathrm{HCl}$, EtOH, reflux, $3 \mathrm{~d}$; (e) $\mathrm{KOH}, 1$,2-dimethoxyethane, reflux, $3 \mathrm{~d}$; (f) 1) $\left.\mathrm{NaNO}_{2}, \mathrm{HCl} / \mathrm{AcOH}, 0{ }^{\circ} \mathrm{C}, 3 \mathrm{~h}, 2\right) \mathrm{SnCl}_{2}, \mathrm{HCl}$, RT, 2 h; (g) diethyl oxalate, NaH, DMF, RT, o.n.; (h) Synthon B, AcOH, reflux, 4 d; (i) 2-nitrobenzenesulfonyl chloride, $\mathrm{NEt}_{3}, \mathrm{CH}_{2} \mathrm{Cl}_{2}, 0^{\circ} \mathrm{C}$ to $\mathrm{RT}, 15 \mathrm{~min}$; (j) 3-dimethylamino-1-propyl hydrochloride, $\mathrm{K}_{2} \mathrm{CO}_{3}$, $\mathrm{DMF}, 60^{\circ} \mathrm{C}$, o.n.; (k) PhSH, $\mathrm{Cs}_{2} \mathrm{CO}_{3}$, DMF, $40{ }^{\circ} \mathrm{C}, 5$ h; (l) Synthon C, HATU, DIPEA, DMF, RT, 6 h; (m) NaCN, NH $\mathrm{OH}_{4}, \mathrm{NH}_{4} \mathrm{Cl}, \mathrm{H}_{2} \mathrm{O} / \mathrm{EtOH}, 50{ }^{\circ} \mathrm{C}$, o.n.; (n) $\mathrm{BzCl}, \mathrm{K}_{2} \mathrm{CO}_{3}, \mathrm{H}_{2} \mathrm{O} / \mathrm{THF}, \mathrm{RT}, 2 \mathrm{~h}$; (o) $\mathrm{HCl} / \mathrm{AcOH}$, reflux, $5 \mathrm{~d}$; (p) $t$-butyl acetate, $\mathrm{HClO}_{4}$, RT, o.n.; (q) $\mathrm{KOH} 5 \mathrm{M}$, dioxane, RT, 18 h.; (r) Synthon D, HATU, NEt3, DMF, RT, 4 h; (s) TFA/DCM 50/50, RT, 1.5 h; (t) chelating agent, DIPEA, DMF, RT, $4 \mathrm{~h}$. The values noted in parentheses are the estimated charge when each chelator is complexed to $\mathrm{Ga}^{3+}$ at $\mathrm{pH}$ 7.4. 
Table 1. Percentage of inhibition constants, intact compound after $4 h$, partition coefficients and radiochemical purities of compounds tested in this study

\begin{tabular}{|c|c|c|c|c|}
\hline Compound & $K \mathrm{i}(\mathrm{nM})^{\mathrm{a}}$ & $\begin{array}{c}\% \text { intact after } \\
4 \mathrm{~h}^{\mathrm{b}}\end{array}$ & $\log \mathrm{D}^{c}$ & $\begin{array}{l}\text { Radiochemical purity } \\
\text { (by radio-HPLC) }\end{array}$ \\
\hline$\left[{ }^{\text {nat } / 68} \mathrm{Ga}\right] \mathrm{Ga}-3 \mathrm{BP}-228$ & $1.35[0.99-1.83]$ & $80 \%$ & -2.45 & $>99 \%$ \\
\hline$\left[{ }^{\text {nat } / 68 \mathrm{Ga}] \mathrm{Ga}-D O T A G A-16}\right.$ & $3.59[3.03-4.26]$ & $78 \%$ & -1.75 & $>99 \%$ \\
\hline$\left[{ }^{\text {nat } / 68} \mathrm{Ga}\right] \mathrm{Ga}-N O T A-16$ & $0.73[0.60-0.88]$ & $>99 \%$ & -1.85 & $94 \%$ \\
\hline [nat/68Ga]Ga-NODAGA-16 & $1.75[0.77-3.96]$ & $>99 \%$ & -1.74 & $97 \%$ \\
\hline$\left[{ }^{\text {nat } / 68} \mathrm{Ga}\right] \mathrm{Ga}-\mathrm{THP}-16$ & $1.80[1.55-2.10]$ & $90 \%$ & -1.17 & $99 \%$ \\
\hline [nat/68 Ga]Ga-bisDOTAGA-16 & $61.9[51.9-73.8]$ & $78 \%$ & -3.62 & $>99 \%$ \\
\hline [nat/68Ga]Ga-bisNODAGA-16 & $9.05[7.28-11.2]$ & $>99 \%$ & -3.44 & $>99 \%$ \\
\hline$\left[{ }^{\text {nat } / 68} \mathrm{Ga}\right] \mathrm{Ga}-3 \mathrm{BP}-227$ & $0.55[0.51-0.59]$ & $90 \%$ & -2.62 & $98 \%$ \\
\hline$\left[{ }^{\mathrm{nat} / 68} \mathrm{Ga}\right] \mathrm{Ga}-\mathrm{DOTA}-\mathrm{NT}-20.3$ & $10.0[6.51-15.4]$ & N.D. & -2.50 & $>99 \%$ \\
\hline
\end{tabular}

${ }^{a} K_{\mathrm{i}}$ values are presented as "mean [95\% confidence interval]" and were determined using ${ }^{{ }^{n t} \mathrm{G}} \mathrm{Ga}-\mathrm{compound}$ and [ $\left.{ }^{125 I}\right] \mathrm{I}-\mathrm{Tyr}^{3}{ }^{3}$ neurotensin as the radioligand. bercentage of intact compound after $4 \mathrm{~h}$ incubation in mouse serum at $37^{\circ} \mathrm{C}$ using ${ }^{\text {nat }} \mathrm{Ga}-\mathrm{com}-$ pounds. Partition coefficients $(\log \mathrm{D})$ were determined at $\mathrm{pH} 7.4$ using ${ }^{68} \mathrm{Ga}$-compounds and are presented as mean. N.D.: not determined.

PET-MRI Imaging and Biodistribution. In order to evaluate the biodistribution of each compound, the radiolabeled tracers were injected intravenously $(500$ pmol, 3$8 \mathrm{MBq}$ ) in the lateral tail vein of nude mice bearing a xenograft of human colorectal cancer (HT-29) in the flank. This tumor model expresses NTS $1 .{ }^{49}$ Static PET-MRI images were recorded between $1.5 \mathrm{~h}$ and $2 \mathrm{~h}$ post injection.

First, we chose to compare [ $\left.{ }^{68} \mathrm{Ga}\right] \mathrm{Ga}-3 \mathrm{BP}-228$ to two references: $\left.{ }^{68} \mathrm{Ga}\right] \mathrm{Ga}-3 \mathrm{BP}-227$ and a well-validated NTS $\mathrm{N}_{1}$ peptide agonist named $\left[{ }^{68} \mathrm{Ga}\right] \mathrm{Ga}-\mathrm{DOTA}-\mathrm{NT}-20.3 .{ }^{51,52,11}$ As could be expected from the results of Schulz et al. with ${ }^{111}$ In-labeled compounds, $\left[{ }^{68} \mathrm{Ga}\right] \mathrm{Ga}-3 \mathrm{BP}-228$ showed faster blood clearance than its isomer. Indeed, a high level of circulating activity was observed for $\left[{ }^{68} \mathrm{Ga}\right] \mathrm{Ga}-3 \mathrm{BP}-227$, leading to a tumor-to-blood ratio of $1.243 \pm 0.279$ while a ratio of $7.540 \pm 2.938$ was obtained with $\left[{ }^{68} \mathrm{Ga}\right] \mathrm{Ga}-3 \mathrm{BP}-228$ (Table 2, Figure S49).

In comparison, ${ }^{68} \mathrm{Ga}$ Ga-DOTA-NT-20.3 showed a typical biodistribution profile for a NTS 1 peptide agonist, with a lower uptake in the tumor compared to $\left.{ }^{68} \mathrm{Ga}\right] \mathrm{Ga}-3 \mathrm{BP}-228$, but a minimal activity in all the other tissues (apart from kidneys), giving tumor-to-organ ratios around two times higher than $\left[{ }^{68} \mathrm{Ga}\right] \mathrm{Ga}-3 \mathrm{BP}-228$ for the blood, liver, muscle and heart (Table 2, Figure S49).

Table 2. Ex vivo biodistribution and tumor-to-organ ratios of 3BP-227, 3BP-228 and DOTA-NT-20.3

\begin{tabular}{|c|c|c|c|}
\hline & $\begin{array}{l}{\left[{ }^{68} \mathrm{Ga}\right] \mathrm{Ga}-} \\
3 \mathrm{BP}-228\end{array}$ & $\begin{array}{c}{\left[{ }^{68} \mathrm{Ga}\right] \mathrm{Ga}-3 \mathrm{BP}-} \\
227\end{array}$ & $\begin{array}{c}\left.{ }^{68} \mathrm{Ga}\right] \mathrm{Ga}- \\
\text { DOTA-NT- } \\
20.3\end{array}$ \\
\hline
\end{tabular}

\begin{tabular}{|c|c|c|c|}
\hline $\begin{array}{c}\text { Uptake } \\
(\% \mathrm{ID} / \mathrm{g})\end{array}$ & $\mathrm{n}=4$ & $\mathrm{n}=4$ & $\mathrm{n}=4$ \\
\hline Blood & $1.083 \pm 0.222$ & $9.155 \pm 0.705^{* * *}$ & $0.088 \pm 0.017^{*}$ \\
\hline Liver & $0.908 \pm 0.129$ & $3.725 \pm 2.181^{*}$ & $0.103 \pm 0.022$ \\
\hline $\begin{array}{c}\text { Gall- } \\
\text { bladder }\end{array}$ & $3.347 \pm 3.208$ & $4.240 \pm 1.786$ & $0.108 \pm 0.071$ \\
\hline Kidneys & $2.525 \pm 0.641$ & $4.775 \pm 1.055^{*}$ & $5.705 \pm 1.457^{* *}$ \\
\hline Spleen & $0.408 \pm 0.085$ & $1.610 \pm 0.147^{* * *}$ & $0.113 \pm 0.026^{* *}$ \\
\hline Heart & $0.555 \pm 0.102$ & $3.518 \pm 0.843^{* * *}$ & $0.053 \pm 0.019$ \\
\hline Lungs & $1.060 \pm 0.164$ & $4.675 \pm 0.429^{* * *}$ & $0.173 \pm 0.036^{* *}$ \\
\hline Muscle & $0.348 \pm 0.345$ & $0.985 \pm 0.114^{* *}$ & $0.025 \pm 0.010$ \\
\hline Intestine & $1.093 \pm 0.098$ & $2.018 \pm 0.497^{* *}$ & $0.405 \pm 0.072^{*}$ \\
\hline Carcass & $1.125 \pm 0.560$ & $4.253 \pm 0.621^{* * *}$ & $0.160 \pm 0.022^{*}$ \\
\hline Tumor & $7.825 \pm 2.507$ & $11.238 \pm 1.704^{*}$ & $1.655 \pm 0.497^{* *}$ \\
\hline $\begin{array}{c}\text { Tumor- } \\
\text { to-organ } \\
\text { ratios }\end{array}$ & $\mathrm{n}=4$ & $\mathrm{n}=4$ & $\mathrm{n}=4$ \\
\hline Blood & $7.540 \pm 2.938$ & $1.243 \pm 0.279$ & $19.08 \pm 5.778^{* *}$ \\
\hline Intestine & $1.093 \pm 0.098$ & $2.018 \pm 0.497^{* *}$ & $0.405 \pm 0.072^{*}$ \\
\hline Kidneys & $3.125 \pm 0.695$ & $2.393 \pm 0.346$ & $0.300 \pm 0.110^{* *}$ \\
\hline
\end{tabular}

(Top) Ex vivo biodistribution of $\left[{ }^{68} \mathrm{Ga}\right] \mathrm{Ga}-3 \mathrm{BP}-228$, $\left[{ }^{68} \mathrm{Ga}\right] \mathrm{Ga}-3 \mathrm{BP}-227$ and $\left[{ }^{68} \mathrm{Ga}\right] \mathrm{Ga}-D O T A-N T-20.3,2 \mathrm{~h}$ p.i. Values are expressed as the percentage of injected dose per gram of tissue (\%ID/g $\pm \mathrm{SD})$. (Bottom) Tumor-to-organ ratios from the ex vivo biodistribution. Values are expressed as means \pm SD. Statistical analysis by one-way ANOVA with [ $\left.{ }^{68} \mathrm{Ga}\right] \mathrm{Ga}-$ 3BP-228 as control group, followed by Bonferroni correction, " $\mathrm{p}<0.05,{ }^{* * *} \mathrm{p}<0.01$, and ${ }^{* * * *} \mathrm{p}<0.001$. 
Overall, these results showed that NTS 1 small molecule antagonists have a good potential for ${ }^{68} \mathrm{Ga}$-PET diagnosis but that their pharmacokinetics needed to be further optimized.

Next, we undertook the evaluation of our seven novel derivatives. All these compounds showed important differences in terms of biodistribution. For instance, administration of the THP-derivative gave a much stronger signal in lungs, spleen and liver $(12.7 \pm 4.1 \% \mathrm{ID} / \mathrm{g}, 46.4 \pm$ $9.3 \% \mathrm{ID} / \mathrm{g}, 42.0 \pm 8.1 \% \mathrm{ID} / \mathrm{g}$ respectively) than all the other compounds $(0.5-1.3 \% \mathrm{ID} / \mathrm{g}$ ) (Figure 2). Moreover, the tumor uptake of $\left.{ }^{68} \mathrm{Ga}\right] \mathrm{Ga}-\mathrm{THP}-16$ was very low (1.33 \pm $0.35 \% \mathrm{ID} / \mathrm{g}$ ) (Tables S2 and S3, Figure S49). We assume that this behavior results from the lipophilicity of the THP moiety. ${ }^{53}$ Indeed, ${ }^{68} \mathrm{Ga}$ ]Ga-THP-16 has a $\log D$ of -1.17 while the other compounds have $\log D$ s between -1.75 and -3.62 (Table 1).

The other four compounds, labeled with a single macrocyclic chelator, gave fairly similar profiles for most organs. The main difference was observed in the gallbladder and intestines (Figure 2, Figure 3). Indeed, the NOTA/NODAGA-compounds showed a much stronger signal in these organs than DOTA/DOTAGAcompounds, suggesting a partial hepatobiliary excretion pathway for these derivatives. This may limit their interest for the imaging of abdominal tumors. Concerning tumor uptake, we observed on PET images that the compounds $\left[{ }^{68} \mathrm{Ga}\right] \mathrm{Ga}-\mathrm{NODAGA}-16$ and $\left[{ }^{68} \mathrm{Ga}\right] \mathrm{Ga}-3 \mathrm{BP}-228$ showed a better accumulation in the tumor than $\left.{ }^{68} \mathrm{Ga}\right] \mathrm{Ga}-$ NOTA-16 and [ ${ }^{68} \mathrm{Ga}$ ]Ga-DOTAGA-16 (Figure 2). Indeed,
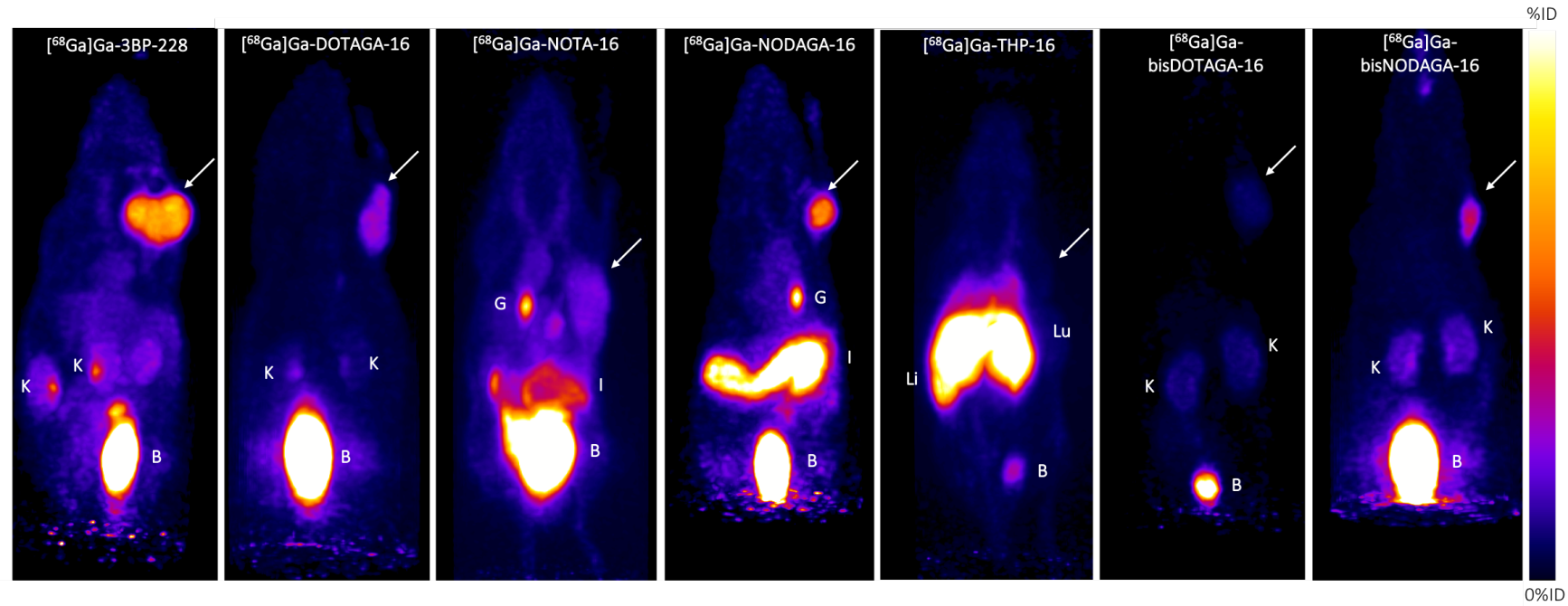

Figure 2. Maximum intensity projection (MIP) images obtained between $1.5 \mathrm{~h}$ and $2 \mathrm{~h}$ p.i. of $\left[{ }^{68} \mathrm{Ga}\right] \mathrm{Ga}-3 \mathrm{BP}-228,\left[{ }^{68} \mathrm{Ga}\right] \mathrm{Ga}-$ DOTAGA-16, $\quad\left[{ }^{68} \mathrm{Ga}\right] \mathrm{Ga}-N O T A-16, \quad\left[{ }^{68} \mathrm{Ga}\right] \mathrm{Ga}-N O D A G A-16, \quad\left[{ }^{68} \mathrm{Ga}\right] \mathrm{Ga}-\mathrm{THP}-\mathbf{1 6}, \quad\left[{ }^{68} \mathrm{Ga}\right] \mathrm{Ga}-$-bisDOTAGA-16, and $\left[{ }^{68} \mathrm{Ga}\right] \mathrm{Ga}-$ bisNODAGA-16. The tumor is showed by a white arrow. Abbreviations: $\mathrm{G}$, gallbladder; I, intestines; $\mathrm{K}$, kidneys; $\mathrm{B}$, bladder; Li, liver; Lu, lungs. 
Table 3. Ex vivo biodistribution and tumor-to-organ ratios at $2 \mathrm{~h}$ p.i.

\begin{tabular}{|c|c|c|c|c|c|c|c|}
\hline & $\begin{array}{c}{\left[{ }^{68} \mathrm{Ga}\right] \mathrm{Ga}-3 \mathrm{BP}-} \\
228\end{array}$ & $\begin{array}{c}{\left[{ }^{68} \mathrm{Ga}\right] \mathrm{Ga}-} \\
\text { DOTAGA-16 }\end{array}$ & $\begin{array}{l}{\left[{ }^{68} \mathrm{Ga}\right] \mathrm{Ga}-} \\
\text { NOTA-16 }\end{array}$ & $\begin{array}{c}{\left[{ }^{68} \mathrm{Ga}\right] \mathrm{Ga}-} \\
\text { NODAGA-16 }\end{array}$ & $\begin{array}{l}{\left[{ }^{68} \mathrm{Ga}\right] \mathrm{Ga}-\text { bis- }} \\
\text { DOTAGA-16 }\end{array}$ & $\begin{array}{c}{\left[{ }^{68} \mathrm{Ga}\right] \mathrm{Ga}-} \\
\text { bisNODAGA-16 }\end{array}$ & $\begin{array}{c}{\left[{ }^{68} \mathrm{Ga}\right] \mathrm{Ga}-} \\
\text { DOTA-NT-20.3 }\end{array}$ \\
\hline $\begin{array}{l}\text { Uptake } \\
(\% \mathrm{ID} / \mathrm{g})\end{array}$ & $\mathrm{n}=4$ & $\mathrm{n}=4$ & $\mathrm{n}=4$ & $\mathrm{n}=4$ & $\mathrm{n}=4$ & $\mathrm{n}=4$ & $\mathrm{n}=4$ \\
\hline Blood & $1.083 \pm 0.222$ & $0.658 \pm 0.039$ & $1.330 \pm 0.654$ & $1.915 \pm 0.526$ & $0.135 \pm 0.031^{*}$ & $0.393 \pm 0.108$ & $0.088 \pm 0.017^{*}$ \\
\hline Liver & $0.908 \pm 0.129$ & $0.523 \pm 0.025$ & $1.183 \pm 0.325$ & $1.005 \pm 0.211$ & $0.250 \pm 0.057$ & $0.387 \pm 0.072$ & $0.103 \pm 0.022$ \\
\hline Gallbladder & $3.347 \pm 3.208$ & $2.803 \pm 1.062$ & - & $10.610 \pm 12.404$ & $0.367 \pm 0.040$ & $1.363 \pm 0.993$ & $0.108 \pm 0.071$ \\
\hline Kidneys & $2.525 \pm 0.641$ & $1.943 \pm 0.525$ & $2.540 \pm 0.713$ & $3.775 \pm 1.811$ & $3.353 \pm 0,523$ & $3.377 \pm 0.425$ & $5.705 \pm 1.457^{* *}$ \\
\hline Spleen & $0.408 \pm 0.085$ & $0.310 \pm 0.174$ & $0.445 \pm 0.177$ & $0.448 \pm 0.141$ & $0.118 \pm 0.019$ & $0.207 \pm 0.025$ & $0.113 \pm 0.026^{* *}$ \\
\hline Heart & $0.555 \pm 0.102$ & $0.335 \pm 0.019$ & $0.518 \pm 0.205$ & $0.750 \pm 0.249$ & $0.103 \pm 0.021^{* *}$ & $0.167 \pm 0.038^{*}$ & $0.053 \pm 0.019$ \\
\hline Lungs & $1.060 \pm 0.164$ & $0.678 \pm 0.194$ & $1.165 \pm 0.527$ & $1.285 \pm 0.452$ & $0.255 \pm 0.031$ & $0.437 \pm 0.071$ & $0.173 \pm 0.036^{* *}$ \\
\hline Muscle & $0.348 \pm 0.345$ & $0.205 \pm 0.044$ & $0.413 \pm 0.114$ & $1.475 \pm 0.997^{* *}$ & $0.138 \pm 0.083$ & $0.210 \pm 0.061$ & $0.025 \pm 0.010$ \\
\hline Intestine & $1.093 \pm 0.098$ & $0.678 \pm 0.127$ & $4.080 \pm 1.272$ & $4.293 \pm 0.483$ & $0.183 \pm 0.083$ & $0.267 \pm 0.097$ & $0.405 \pm 0.072^{*}$ \\
\hline Carcass & $1.125 \pm 0.560$ & $1.043 \pm 0.474$ & $1.225 \pm 0.513$ & $1.603 \pm 0.496$ & $0.313 \pm 0.036$ & $0.610 \pm 0.154$ & $0.160 \pm 0.022^{*}$ \\
\hline Tumor & $7.825 \pm 2.507$ & $3.978 \pm 0.564^{* * *}$ & $3.140 \pm 0.286^{* * *}$ & $8.148 \pm 1.038$ & $1.305 \pm 0.062^{* * *}$ & $4.917 \pm 0.776^{*}$ & $1.655 \pm 0.497^{* *}$ \\
\hline $\begin{array}{l}\text { Tumor-to- } \\
\text { organ ratios }\end{array}$ & $\mathrm{n}=4$ & $\mathrm{n}=4$ & $\mathrm{n}=4$ & $\mathrm{n}=4$ & $\mathrm{n}=4$ & $\mathrm{n}=4$ & $\mathrm{n}=4$ \\
\hline Blood & $7.540 \pm 2.938$ & $6.093 \pm 1.173$ & $2.788 \pm 1.172^{*}$ & $4.468 \pm 1.085$ & $10.028 \pm 2.189$ & $13.190 \pm 4.216^{*}$ & $19.083 \pm 5.778^{* *}$ \\
\hline Intestine & $7.145 \pm 2.064$ & $6.125 \pm 2.026$ & $0.808 \pm 0.167^{*}$ & $1.900 \pm 0.177$ & $8.843 \pm 5.184$ & $19.747 \pm 5.633^{* * *}$ & $4.290 \pm 1.899$ \\
\hline Kidneys & $3.125 \pm 0.695$ & $2.158 \pm 0.655$ & $1.288 \pm 0.244^{* *}$ & $2.555 \pm 1.116$ & $0.393 \pm 0.051$ & $1.450 \pm 0.053^{* *}$ & $0.300 \pm 0.110^{* * *}$ \\
\hline
\end{tabular}

Values are expressed as mean \pm SD. Data for THP-16 are shown in tables S2 and S3. Statistical analysis by one-way ANOVA with [ $\left.{ }^{68} \mathrm{Ga}\right] \mathrm{Ga}-3 \mathrm{BP}-228$ as control group, followed by Bonferroni correction, ${ }^{*} \mathrm{p}<0.05,{ }^{* *} \mathrm{p}<0.01$, and ${ }^{* * *} \mathrm{p}<0.001$.

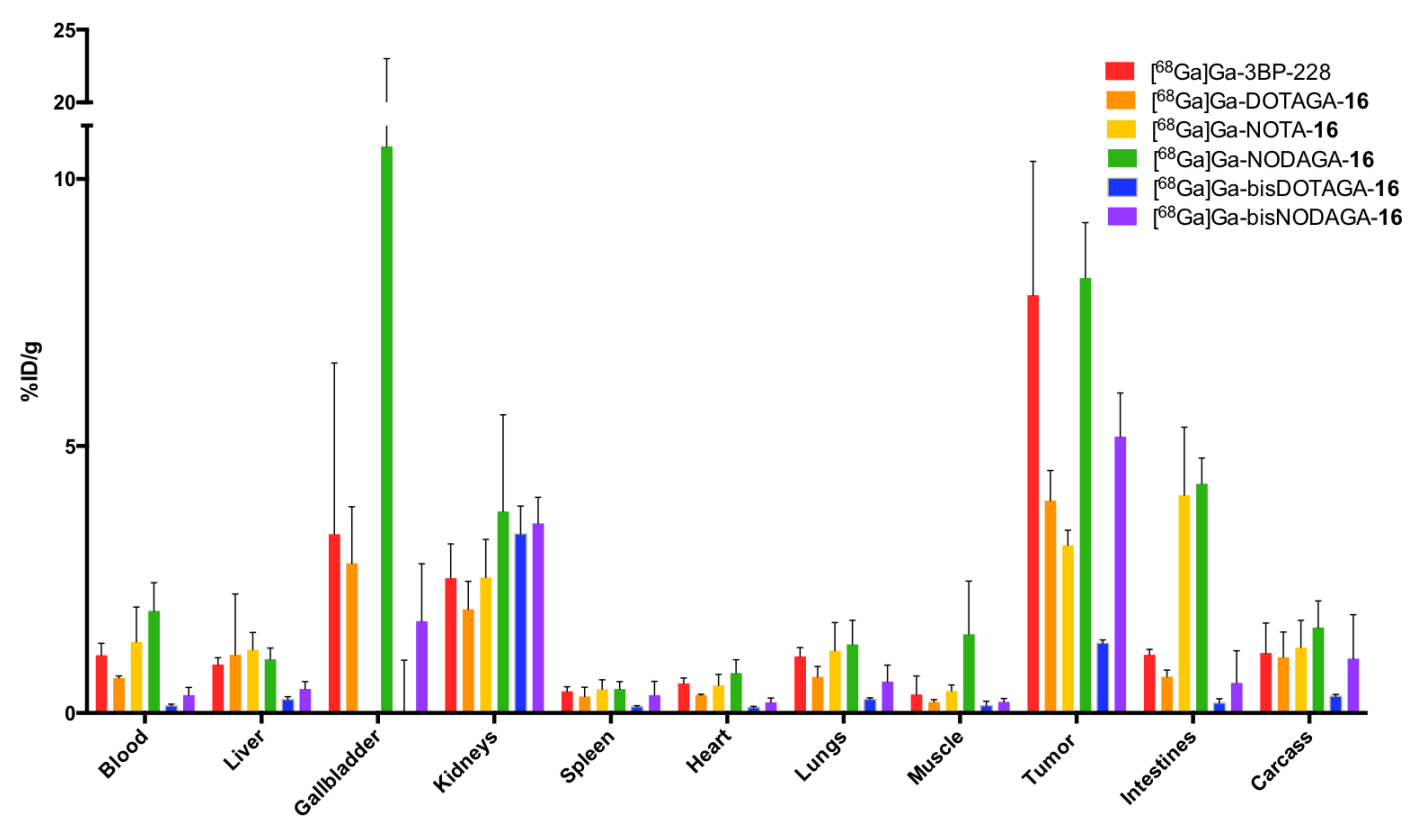

Figure 3. Ex vivo biodistribution data of ${ }^{68} \mathrm{Ga}$-compounds $2 \mathrm{~h}$ p.i. Values are expressed as the percentage of injected dose per gram $(\% \mathrm{ID} / \mathrm{g}$, mean $\pm \mathrm{SD})$ for each collected organ. Data for $\left[{ }^{68} \mathrm{Ga}\right] \mathrm{Ga}-\mathrm{THP}-\mathbf{1 6}$ are presented in table S2. 
In order to evaluate the specificity for NTS 1 , a blocking experiment (in the presence of a 100-fold molar excess of SR142948A) was carried out with the tracers $\left[{ }^{68} \mathrm{Ga}\right] \mathrm{Ga}-$ bisNODAGA-16, $\left.{ }^{68} \mathrm{Ga}\right] \mathrm{Ga}-D O T A G A-16$ and $\left[{ }^{68} \mathrm{Ga}\right] \mathrm{Ga}-$ 3BP-228. The uptake in all isolated organs remained essentially unchanged, apart from tumor uptake whose value decreased by a factor of 2 to 5 (Figure 4, Table S4). PET-MRI imaging confirmed the biodistribution results (Figure S50). These results demonstrate the specificity of these tracers for neurotensin receptor-positive tumors.

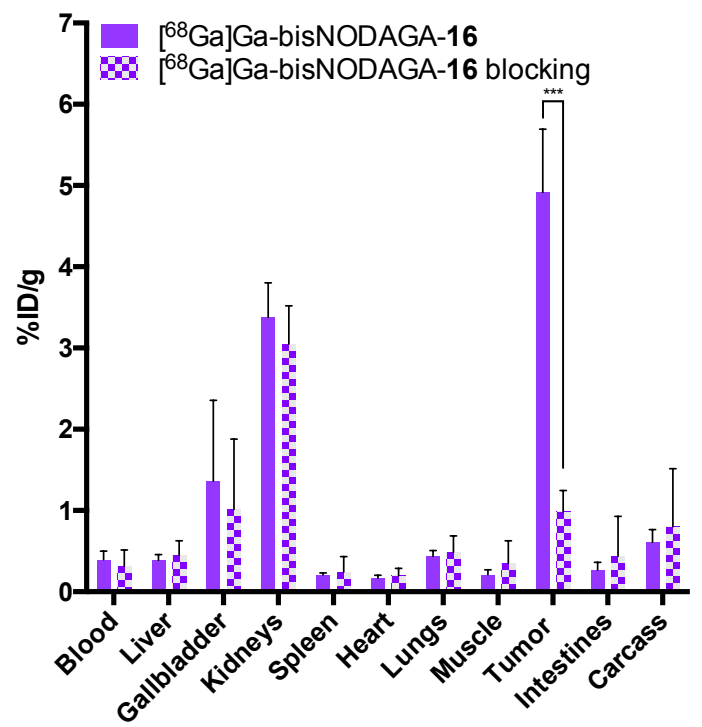

Figure 4. Ex vivo biodistribution of [ $\left.{ }^{68} \mathrm{Ga}\right] \mathrm{Ga}$-bisNODAGA-16 $2 \mathrm{~h}$ p.i., with or without a 100-fold excess of SR142948A. Data were analyzed by an unpaired two-tailed Student's t-test $\left({ }^{* * *} \mathrm{p}<0.001\right)$.

In vitro and in vivo evaluation of $\left[{ }^{68} \mathrm{Ga}\right] \mathrm{Ga}-$ bisNODAGA-16. In order to determine whether the uptake of the tracer bisNODAGA-16 in HT29 tumor was mediated by $\mathrm{NTS}_{1}, \mathrm{NTS}_{2}$ or both receptors, an in vitro competition assay on HT29 cells was performed (Figures S51). The binding of $\left.{ }^{68} \mathrm{Ga}\right] \mathrm{Ga}$-bisNODAGA-16 to HT29 cells was inhibited by an excess of SR142948A or neurotensin, but not by levocabastine, a histamine $\mathrm{H}_{1}$ receptor antagonist that blocks NTS ${ }_{2}{ }^{20}$ These results suggest that the tumor uptake observed in vivo, in this model, is primarily due to binding to NTS 1 . The antagonistic properties of the lead compound ${ }^{\text {nat }}$ Ga-bisNODAGA-16 were confirmed in a calcium flux mobilization assay performed on $\mathrm{CHO}$ cells expressing human recombinant $\mathrm{NTS}_{1}\left(\mathrm{IC}_{50}=141 \mathrm{nM}\right.$; $\mathrm{K}_{\mathrm{B}}=13 \mathrm{nM}$; Figure S52).

[ ${ }^{68} \mathrm{Ga}$ ]Ga-bisNODAGA-16 was further evaluated in a model of pancreatic ductal adenocarcinoma (subcutaneous xenografts of human AsPC- 1 tumor cells). ${ }^{11}$ PET/CT images were recorded 50-70 min and 90-110 min after injection (Figure S53). Tumor masses could be easily detected as early as $60 \mathrm{~min}$ after injection. A post-mortem biodistribution study was performed $2 \mathrm{~h}$ post-injection, which confirmed the accumulation of the radioactive tracer in the tumor (Table S5).

\section{CONCLUSION}

Since the discovery of NTS 1 receptor overexpression in many tumors, considerable efforts have been undertaken to develop NTS1-targeted radiopharmaceuticals that may improve cancer diagnosis and stratification (the reader is encouraged to refer to Maschauer and Prante's excellent review on the topic). ${ }^{12}$ Unfortunately, despite extensive optimization work, very few tracers based on neurotensin peptide analogs have been tested in patients, and their results have so far been disappointing. ${ }^{16,54,55}$ In this context, the emergence of nonpeptide antagonist radioligands of $\mathrm{NTS}_{1}$ is a new source of hope. While efforts have until now been concentrated on ${ }^{177} \mathrm{Lu}$-labeling of these compounds for internal vectorized radiotherapy, here we investigated whether they could be adapted to the elaboration of NTS 1 -specific ${ }^{68} \mathrm{Ga}$-PET imaging tracers to form a theranostic pair.

In a seminal paper published in 2012, Fani et al. stated that "the chelate makes the difference", stressing that the structure of a chelating agent can greatly influence the biodistribution of a tracer. ${ }^{56}$ Since then, numerous teams confirmed this observation. ${ }^{35-38,40,57-61}$ By evaluating seven different chelating agents introduced on the same $\mathrm{NTS}_{1}$ antagonist molecule, we were able to identify a promising new PET tracer, $\left.{ }^{68} \mathrm{Ga}\right] \mathrm{Ga}$-bisNODAGA-16, that showed rapid accumulation in the tumor $(4.917 \pm 0.776 \% \mathrm{ID} / \mathrm{g}, 2 \mathrm{~h}$ p.i.), and fast clearance from blood and other organs. This behavior led to contrasted PET-MRI images, with tumorto-organ ratios of $1.45 \pm 0.05,13.2 \pm 4.2$ to $24.9 \pm 8.6$ for kidneys, blood and muscle respectively. This antagonist showed a biodistribution profile similar to that of the agonist peptide analogue $\left[{ }^{68} \mathrm{Ga}\right] \mathrm{Ga}-\mathrm{DOTA}-\mathrm{NT}-20.3$, with comparable or even better tumor-to-organ ratios for organs such as kidneys, spleen, heart, lungs and intestines.

Unfortunately, to date, the effect of the chelating agent on the pharmacokinetics of a tracer is still hard to predict and needs to be evaluated in vivo. For example, although a study by Young's et al. has found that the introduction of THP on a PSMA-radiotracer could give very good results, ${ }^{62}$ in our study, the THP derivative showed poor tumor uptake and high accumulation in spleen, kidneys, and lungs. While tracers such as $\left[{ }^{68} \mathrm{Ga}\right] \mathrm{Ga}-J M V 6659$ show $\mathrm{NTS}_{1-}$ mediated accumulation in the spleen and blood (which the authors suggest is related to specific binding to NTS $\mathrm{N}_{1}$ expressed on blood cells), ${ }^{63}$ we believe that the observed biodistribution for $\left[{ }^{68} \mathrm{Ga}\right] \mathrm{Ga}-\mathrm{THP}-\mathbf{1 6}$ results primarily from its lipophilicity (or lack of in vivo stability), which leads to unfavorable hepatobiliary clearance. Several studies have suggested that the charge of the chelate would have a major impact on the biodistribution. ${ }^{39,58,36}$ In our specific case, 
compounds with neutral charge complexes presented a better tumor accumulation in vivo.

On a positive note, it appears that the addition of an extrachelator is a reliable and straightforward strategy to speed up the renal excretion of tracers, leading to better images, provided that the affinity is retained..$^{41}$ In addition, it increases the molar activities that can be potentially achieved. However, it should be noted that this approach may complicate the pharmaceutical development of the tracer, as it is difficult to predict which chelator binds to the radiometal. Saturation of the molecule with ${ }^{\text {nat }} \mathrm{Ga}$, after radiolabeling, may be necessary to obtain a homogeneous tracer.

\section{EXPERIMENTAL SECTION}

General Information. All chemicals were purchased from Merck, Acros Organics and Alfa Aesar and used without further purification. DOTA-NHS, DOTAGA-anhydride, NOTA-NHS, $(R)$-NODAGA-NHS, THP-NCS, DOTAGA $(t \mathrm{Bu})_{4}$ and $\operatorname{NODAGA}(t \mathrm{Bu})_{3}$ were provided by CheMatech (Dijon, France). Moisture sensitive reactions were performed under nitrogen or argon atmosphere. The purity of final compounds was determined by RP-HPLC-MS and was $>95 \%$ for all tested compounds unless stated.

Experimental Procedures and Characterization Data for synthon A. 2-isopropylacetanilide (1). A solution containing 2isopropylaniline ( $5 \mathrm{~mL}, 35.3 \mathrm{mmol}, 1$ equiv.) and toluene $(48 \mathrm{~mL})$ was cooled in an ice bath. Acetic anhydride $(3.52 \mathrm{~mL}, 37.1 \mathrm{mmol}$, 1.05 equiv.) was added slowly. After stirring for 45 minutes at $\mathrm{RT}$, the reaction medium was evaporated. The red oil obtained was then taken up with petroleum ether $(15 \mathrm{~mL})$. The white precipitate formed was filtered and dried under vacuum to give a white solid (5.83 g, 93\%, purity >99\%). RP-HPLC-MS: $t_{r}=3.82$ min., $m / z$ calculated for $\mathrm{C}_{11} \mathrm{H}_{15} \mathrm{NO}[\mathrm{M}+\mathrm{H}]^{+} 178.1$, found 178.0. $\mathrm{R}_{\mathrm{f}}$ $\left(\mathrm{CH}_{2} \mathrm{Cl}_{2} / \mathrm{MeOH}, 98 / 2\right)=0.26 .{ }^{1} \mathrm{H}-\mathrm{NMR}\left(500 \mathrm{MHz}, \mathrm{CDCl}_{3}\right): \delta=1.25$ (d, J=6.8 Hz, 6H), $2.2(\mathrm{~s}, 3 \mathrm{H}), 3.05$ (hept, J=6.8 Hz, 1H), 7-7.3 (m, $4 \mathrm{H}), 7.6(\mathrm{~m}, 1 \mathrm{H}) \mathrm{ppm} ;{ }^{13} \mathrm{C}-\mathrm{NMR}\left(126 \mathrm{MHz}, \mathrm{CDCl}_{3}\right): \delta=23.2\left(\mathrm{CH}_{3}\right)$, $24.3\left(\mathrm{CH}_{3}\right), 28.1(\mathrm{CH}), 125.4(\mathrm{CH}), 125.8(\mathrm{CH}), 126.4(\mathrm{CH}), 126.5$ (CH), $134.1(\mathrm{C}), 141.1(\mathrm{C}), 168.9(\mathrm{C}) \mathrm{ppm} . \mathrm{mp}: 72^{\circ} \mathrm{C}$.

4-Bromo-2-isopropylacetanilide (2). A solution of $\mathrm{N}$-bromo succinimide (7.53 g, $42.3 \mathrm{mmol}, 1.5$ equiv.) in DMF (14 mL) was added dropwise over 45 minutes to a solution of 2 -isopropylacetanilide (1) (5 g, $28.2 \mathrm{mmol}, 1$ equiv.) in DMF (14 mL). The mixture was stirred at RT overnight. The reaction mixture was evaporated to obtain a yellow oil, extracted with $\mathrm{CH}_{2} \mathrm{Cl}_{2}$, washed with acidic water, brine and dried over $\mathrm{MgSO}_{4}$. The solvent was evaporated to give a yellow solid, which was purified by flashcolumn chromatography (A: $\mathrm{CH}_{2} \mathrm{Cl}_{2}, \mathrm{~B}: \mathrm{CH}_{2} \mathrm{Cl}_{2} / \mathrm{MeOH}$ 9:1; with the following gradient program: $0 \%$ to $40 \%$ of $\mathrm{B}$ in $25 \mathrm{CV}$ ). A white solid (4.62 g, 64\%, purity: 93\%) was obtained. RP-HPLCMS: $\mathrm{tr}_{\mathrm{r}}=4.26 \mathrm{~min} ., \mathrm{m} / \mathrm{z}$ calculated for $\mathrm{C}_{11} \mathrm{H}_{14} \mathrm{BrNO}[\mathrm{M}-\mathrm{H}]^{-} 254.0$, found 254.0. $\mathrm{Rf}_{\mathrm{f}}\left(\mathrm{CH}_{2} \mathrm{Cl}_{2} / \mathrm{MeOH}, 98 / 2\right)=0.32 .{ }^{1} \mathrm{H}-\mathrm{NMR}(500 \mathrm{MHz}$, $\left.\mathrm{CDCl}_{3}\right): \delta=1.23(\mathrm{~d}, \mathrm{~J}=6.8 \mathrm{~Hz}, 6 \mathrm{H}), 2.19(\mathrm{~s}, 3 \mathrm{H}), 2.98$ (hept, J=6.8 $\mathrm{Hz}, 1 \mathrm{H}), 7.00$ (br, 1H), 7.30 (d, J=8.5 Hz, 1H), 7.38 (s, 1H), 7.53 (d, $\mathrm{J}=8.5 \mathrm{~Hz}, 1 \mathrm{H}) \mathrm{ppm} ;{ }^{13} \mathrm{C}-\mathrm{NMR}\left(126 \mathrm{MHz}, \mathrm{CDCl}_{3}\right): \delta=23.0\left(\mathrm{CH}_{3}\right)$, $24.3\left(\mathrm{CH}_{3}\right), 28.2(\mathrm{CH}), 119.7(\mathrm{C}), 126.8(\mathrm{CH}), 129.0(\mathrm{CH}), 129.6$ $(\mathrm{CH}), 133.2(\mathrm{C}), 143.0(\mathrm{C}), 168.8(\mathrm{C}) \mathrm{ppm} . \mathrm{mp}: 132^{\circ} \mathrm{C}$.
4-Cyano-2-isopropylacetanilide (3). A mixture of 4-bromo-2isopropylacetanilide (2) (4.8 g, $18.74 \mathrm{mmol}, 1$ equiv.), DMF (22.5 $\mathrm{mL})$, cuprous cyanide $(2.51 \mathrm{~g}, 28.1 \mathrm{mmol}, 1.5$ equiv.) and water $(0.370 \mathrm{~mL})$ was stirred under reflux overnight. After cooling, the reaction medium was concentrated under vacuum and water (58 $\mathrm{mL}$ ) was added to the mixture under stirring. The precipitate was filtered off, rinsed with water and dried under vacuum. The grey/brown solid was purified by flash-column chromatography (A: $\mathrm{CH}_{2} \mathrm{Cl}_{2}$, B: $\mathrm{CH}_{2} \mathrm{Cl}_{2} / \mathrm{MeOH}$ 9:1; with the following gradient program: $0 \%$ to $40 \%$ of B in $25 \mathrm{CV})$. A white solid $(1.23 \mathrm{~g}$, 33\%, purity: $95 \%$ ) was obtained. RP-HPLC-MS: $\mathrm{t}_{\mathrm{r}}=3.65 \mathrm{~min} ., \mathrm{m} / \mathrm{z}$ calculated for $\mathrm{C}_{12} \mathrm{H}_{14} \mathrm{~N}_{2} \mathrm{O}$ [M-H] ${ }^{-}$201.1, found 201.1. ${ }^{1} \mathrm{H}-\mathrm{NMR}(500$ $\left.\mathrm{MHz} \mathrm{CDCl}_{3}\right): \delta=1.28(\mathrm{~d}, \mathrm{~J}=6.8 \mathrm{~Hz}, 6 \mathrm{H}), 2.24$ (s, 3H), 3.01 (hept, $\mathrm{J}=6.8 \mathrm{~Hz}, 1 \mathrm{H}), 7.25$ (br, 1H), 7.49 (d, J=8.5 Hz, 1H), 7.54 (s, 1H), 8.08 (d, J=8.5 Hz, 1H) ppm; ${ }^{13} \mathrm{C}-\mathrm{NMR}\left(126 \mathrm{MHz}, \mathrm{CDCl}_{3}\right): \delta=22.6$ $\left(\mathrm{CH}_{3}\right), 24.7\left(\mathrm{CH}_{3}\right), 27.8(\mathrm{CH}), 108.4(\mathrm{C}), 119.1(\mathrm{C}), 123.4(\mathrm{CH})$, $129.8(\mathrm{CH}), 130.5(\mathrm{CH}), 138.5(\mathrm{C}), 168.4(\mathrm{C}) \mathrm{ppm} . \mathrm{mp}: 139^{\circ} \mathrm{C}$.

4-Cyano-2-isopropylaniline hydrochloride (4). A mixture of 4-cyano-2-isopropylacetanilide (3) (2.5 g, $15.3 \mathrm{mmol}, 1$ equiv.), absolute ethanol $(12 \mathrm{~mL})$ and $1 \mathrm{~N} \mathrm{HCl}(12 \mathrm{~mL})$ was stirred under reflux for three days. A solution of $10 \% \mathrm{NaOH}(7 \mathrm{~mL})$ was added to reach a $\mathrm{pH}$ of 10 . The reaction medium was extracted three times with $\mathrm{CH}_{2} \mathrm{Cl}_{2}$, the organic layers were combined, dried over $\mathrm{MgSO}_{4}$ and concentrated under vacuum. The orange oil obtained was dissolved in diethylether $(36 \mathrm{~mL})$ and $1 \mathrm{M}$ ethereal hydrogen chloride $(10 \mathrm{~mL})$ was added. The white precipitate was filtered off and rinsed with diethylether to give the expected product ( $2.21 \mathrm{~g}, 74 \%$, purity: 91\%). RP-HPLC-MS: $\mathrm{t}_{\mathrm{r}}=4.22 \mathrm{~min}$., $m / z$ calculated for $\mathrm{C}_{10} \mathrm{H}_{13} \mathrm{~N}_{2}{ }^{+}\left[\mathrm{M}+\mathrm{CH}_{3} \mathrm{CN}\right]^{+} 202.3$, found $202.1 .{ }^{1} \mathrm{H}-$ NMR (500 MHz, DMSO-d $): \delta=1.14$ (d, J=6.8 Hz, 6H), 2.96 (hept, $\mathrm{J}=6.8 \mathrm{~Hz}, 1 \mathrm{H}), 6.72(\mathrm{~d}, \mathrm{~J}=8.3 \mathrm{~Hz}, 1 \mathrm{H}), 7.28(\mathrm{~d}, \mathrm{~J}=8.3 \mathrm{~Hz}, 1 \mathrm{H}), 7.34$ (s, 1H) ppm; ${ }^{13} \mathrm{C}-\mathrm{NMR}\left(126 \mathrm{MHz}, \mathrm{DMSO}-\mathrm{d}_{6}\right): \delta=22.4\left(\mathrm{CH}_{3}\right), 26.7$ (C), $107.4(\mathrm{C}), 115.1(\mathrm{C}), 121.3(\mathrm{CH}), 129.7(\mathrm{CH}), 131.1(\mathrm{CH}) \mathrm{ppm}$. $\mathrm{mp}: 186^{\circ} \mathrm{C}$.

4-amino-3-isopropylbenzoic acid hydrochloride (5). A solution of potassium hydroxide ( $16.8 \mathrm{~g}, 0.3 \mathrm{~mol}, 20$ equiv.), water $(18 \mathrm{~mL})$ and 1,2-dimethoxyethane $(1.5 \mathrm{~mL})$ was added to 4 -cyano-2-isopropylaniline hydrochloride (4) $(3.0 \mathrm{~g}$, $15.0 \mathrm{mmol}, 1$ equiv.). The mixture was heated to reflux for three days. After cooling, concentrated $\mathrm{HCl}(12 \mathrm{~mL})$ was added to reach a $\mathrm{pH}$ of 1 and the mixture was then extracted three times with $\mathrm{CH}_{2} \mathrm{Cl}_{2}$. The organic layers were combined, dried over $\mathrm{MgSO}_{4}$ and concentrated to yield an orange solid (2.42 g, 75\%, purity: 97\%). RPHPLC-MS: $\operatorname{tr}_{\mathrm{r}}=3.33 \mathrm{~min}$., $\mathrm{m} / \mathrm{z}$ calculated for $\mathrm{C}_{10} \mathrm{H}_{13} \mathrm{NO}_{2}$ $\left[\mathrm{M}+\mathrm{H}+\mathrm{CH}_{3} \mathrm{CN}\right]^{+}$221.1, found 221.0. $\mathrm{R}_{\mathrm{f}}\left(\mathrm{CH}_{2} \mathrm{Cl}_{2} / \mathrm{MeOH}, 98 / 2\right)=$ 0.3. ${ }^{1} \mathrm{H}-\mathrm{NMR}\left(500 \mathrm{MHz}, \mathrm{CDCl}_{3}\right): \delta=1.30(\mathrm{~d}, \mathrm{~J}=6.8 \mathrm{~Hz}, 6 \mathrm{H}), 2.85$ (hept, $\mathrm{J}=6.8 \mathrm{~Hz}, 1 \mathrm{H}), 6.66(\mathrm{~d}, \mathrm{~J}=8.3 \mathrm{~Hz}, 1 \mathrm{H}), 7.80(\mathrm{dd}, \mathrm{J}=8.3,1.9 \mathrm{~Hz}$, 1H), $7.92(\mathrm{~d}, \mathrm{~J}=1.9 \mathrm{~Hz}, 1 \mathrm{H})$ ppm; ${ }^{13} \mathrm{C}-\mathrm{NMR}\left(126 \mathrm{MHz}, \mathrm{CDCl}_{3}\right): \delta=$ $22.1\left(\mathrm{CH}_{3}\right), 27.8(\mathrm{CH}), 114.7(\mathrm{CH}), 119.1(\mathrm{C}), 128.5(\mathrm{CH}), 129.8$ $(\mathrm{CH}), 131.4(\mathrm{C}), 148.9(\mathrm{C}), 172.5(\mathrm{C}) \mathrm{ppm} . \mathrm{mp}: 130^{\circ} \mathrm{C}$.

3-isopropyl-4-hydrazinobenzoic acid hydrochloride (synthon A). A solution of concentrated $\mathrm{HCl}(25 \mathrm{~mL})$ and $\mathrm{AcOH}(22 \mathrm{~mL})$ was added to 4-amino-3-isopropylbenzoic acid hydrochloride (5) $\left(1.3 \mathrm{~g}, 6.0 \mathrm{mmol}, 1\right.$ equiv.). The mixture was cooled to $-5{ }^{\circ} \mathrm{C}$ and a solution of $\mathrm{NaNO}_{2}(0.62 \mathrm{~g}, 9.0 \mathrm{mmol}, 1.5$ equiv. $)$ in water $(4.5 \mathrm{~mL})$ was added dropwise over 10 minutes. The mixture was stirred at $0{ }^{\circ} \mathrm{C}$ for $3 \mathrm{~h}$ and then cooled to $-10{ }^{\circ} \mathrm{C}$. A solution of stannous chloride dihydrate $(4.11 \mathrm{~g}, 18.0 \mathrm{mmol}, 3.1$ equiv.) in concentrated $\mathrm{HCl}(4.5 \mathrm{~mL})$ was added slowly. The temperature was allowed to rise to RT and the precipitate formed was filtered 
off after $2 \mathrm{~h}$ and rinsed with $1 \mathrm{M} \mathrm{HCl}(5 \mathrm{~mL})$. A yellowish powder (1.29 g, 93\%, purity: 89\%) was obtained after drying over $\mathrm{P}_{2} \mathrm{O}_{5}$. RP-HPLC-MS: $\mathrm{tr}_{\mathrm{r}}=0.4 \mathrm{~min} ., \mathrm{m} / z$ calculated $\mathrm{C}_{10} \mathrm{H}_{14} \mathrm{~N}_{2} \mathrm{O}_{2}[2 \mathrm{M}+\mathrm{H}]^{+}$ 389.2, found 389.2. ${ }^{1} \mathrm{H}-\mathrm{NMR}\left(500 \mathrm{MHz}, \mathrm{DMSO}-\mathrm{d}_{6}\right): \delta=1.19(\mathrm{~d}$, $\mathrm{J}=6.8 \mathrm{~Hz}, 6 \mathrm{H}), 3.14$ (hept, J=6.8 Hz, 1H), 6.98 (d, J=8.4 Hz, 1H), $7.76(\mathrm{~d}, \mathrm{~J}=8.4 \mathrm{~Hz}, 1 \mathrm{H}), 7.78(\mathrm{~s}, 1 \mathrm{H}), 8.31(\mathrm{br}, 1 \mathrm{H}) \mathrm{ppm} ;{ }^{13} \mathrm{C}-\mathrm{NMR}$ (126 MHz, DMSO-d6): $\delta=22.9\left(\mathrm{CH}_{3}\right), 26.5(\mathrm{CH}), 112.6(\mathrm{CH}), 124.0$ (C), $127.0(\mathrm{CH}), 128.5(\mathrm{CH}), 134.7(\mathrm{C}), 146.1(\mathrm{C}), 167.6(\mathrm{C}) \mathrm{ppm}$. mp: $245^{\circ} \mathrm{C}$

Experimental Procedures and Characterization Data for synthon B. Ethyl-4-(2,6-dimethoxyphenyl)-4-hydroxy-2-oxobut-3-enoate (synthon B). Sodium hydride 60\% (0.40 g, 9.96 mmol, 1.2 equiv.) was added to a solution of diethyl oxalate (1.36 g, 9.96 mmol, 1.2 equiv.) in DMF ( $5 \mathrm{~mL}$ ) and the mixture was stirred for 5 minutes. A solution of 2,6-dimethoxyacetophenone ( $1.5 \mathrm{~g}$, $8.3 \mathrm{mmol}$, 1 equiv.) in DMF ( $5 \mathrm{~mL}$ ) was slowly added over 15 minutes. The mixture was then stirred at RT overnight. The reaction medium was extracted with EtOAc three times, ensuring the $\mathrm{pH}$ remained below 6 between each extraction. The organic layers were combined, dried over $\mathrm{MgSO}_{4}$ and concentrated under vacuum. Following recrystallization from EtOH, a yellowish powder $(1.7 \mathrm{~g}$, 73\%, purity: $90 \%)$ was obtained. RPHPLC-MS: $\mathrm{tr}_{\mathrm{r}}=4.90 \mathrm{~min} ., \mathrm{m} / \mathrm{z}$ calculated for $\mathrm{C}_{14} \mathrm{H}_{16} \mathrm{O}_{6}[\mathrm{M}+\mathrm{H}]^{+}$ 281.1, found 281.1. ${ }^{1} \mathrm{H}-\mathrm{NMR}\left(500 \mathrm{MHz}, \mathrm{CDCl}_{3}\right): \delta=1.37(\mathrm{t}, \mathrm{J}=7.1$ $\mathrm{Hz}, 3 \mathrm{H}), 3.82(\mathrm{~s}, 6 \mathrm{H}), 4.35(\mathrm{q}, \mathrm{J}=7.1 \mathrm{~Hz}, 2 \mathrm{H}), 6.59(\mathrm{~d}, \mathrm{~J}=8.4 \mathrm{~Hz}, 2 \mathrm{H})$, 6.61 (s, 1H), 7.34 (t, J=8.4 Hz, 1H), 14.33 (br 1H) ppm; ${ }^{13} \mathrm{C}-\mathrm{NMR}$ $\left(126 \mathrm{MHz}, \mathrm{CDCl}_{3}\right): \delta=14.2\left(\mathrm{CH}_{3}\right), 56.2\left(\mathrm{CH}_{3}\right), 62.5\left(\mathrm{CH}_{2}\right), 104.2$ $(\mathrm{CH}), 106.4(\mathrm{CH}), 117.2(\mathrm{C}), 132.4(\mathrm{CH}), 158.0(\mathrm{C}), 162.6(\mathrm{C}), 163.9$ (C), 195.9 (C) ppm. mp: $103^{\circ} \mathrm{C}$.

Experimental Procedures and Characterization Data for 6. 4(5-(2,6-dimethoxyphenyl)-3-(ethoxycarbonyl)-1H-pyrazol-1yl)-3-isopropylbenzoic acid (6). A mixture of 3-isopropyl-4-hydrazinobenzoic acid hydrochloride (synthon A) (0.56 g, 2.4 mmol, 1.05 equiv.) and ethyl-4-(2,6-dimethoxyphenyl)-4-hydroxy-2-oxobut-3-enoate (synthon B) $(0.65 \mathrm{~g}, 2.3 \mathrm{mmol}, 1$ equiv.) in $\mathrm{AcOH}(8.5 \mathrm{~mL})$ was stirred under reflux for 4 days. The brownish suspension was poured into $15 \mathrm{~mL}$ of ice-bath water and the yellow precipitate was filtered off and washed with water. The yellow solid was purified on a silica plug $\left(\mathrm{CH}_{2} \mathrm{Cl}_{2}\right.$ to $\mathrm{CH}_{2} \mathrm{Cl}_{2} / \mathrm{MeOH}$ 9:1) to obtain the expected product $(0.8 \mathrm{~g}, 80 \%$, purity: 92\%). RP-HPLC-MS: $t_{r}=5.1 \mathrm{~min}, \mathrm{~m} / \mathrm{z}$ calculated for $\mathrm{C}_{24} \mathrm{H}_{26} \mathrm{~N}_{2} \mathrm{O}_{6}[\mathrm{M}+\mathrm{H}]^{+}$439.2, found 439.2. $\mathrm{Rf}\left(\mathrm{CH}_{2} \mathrm{Cl}_{2} / \mathrm{MeOH}, 9 / 1\right)=$ 0.52. ${ }^{1} \mathrm{H}-\mathrm{NMR}\left(500 \mathrm{MHz}, \mathrm{DMSO}-\mathrm{d}_{6}\right): \delta=0.96(\mathrm{~d}, \mathrm{~J}=5.3 \mathrm{~Hz}, 6 \mathrm{H})$, $1.31(\mathrm{t}, \mathrm{J}=7.1 \mathrm{~Hz}, 3 \mathrm{H}), 2.65(\mathrm{~m}, 1 \mathrm{H}), 3.61(\mathrm{~s}, 6 \mathrm{H}), 4.31(\mathrm{q}, \mathrm{J}=7.1 \mathrm{~Hz}$, $2 \mathrm{H}), 6.60(\mathrm{~d}, \mathrm{~J}=8.5 \mathrm{~Hz}, 2 \mathrm{H}), 6.83(\mathrm{~s}, 1 \mathrm{H}), 7.28(\mathrm{~d}, \mathrm{~J}=8.2 \mathrm{~Hz}, 1 \mathrm{H}), 7.31$ $(\mathrm{t}, \mathrm{J}=8.5 \mathrm{~Hz}, 1 \mathrm{H}), 7.76(\mathrm{dd}, \mathrm{J}=8.2,1.8 \mathrm{~Hz}, 1 \mathrm{H}), 7.85$ (d, J=1.8 Hz, 1H), 13.19 (br, 1H) ppm; ${ }^{13} \mathrm{C}-\mathrm{NMR}\left(126 \mathrm{MHz}, \mathrm{DMSO}-\mathrm{d}_{6}\right): \delta=14.7$ $\left(\mathrm{CH}_{3}\right), 27.6\left(\mathrm{CH}_{3}\right), 40.6(\mathrm{CH}), 56.0\left(\mathrm{CH}_{3}\right), 60.8\left(\mathrm{CH}_{2}\right), 104.3(\mathrm{CH})$, $106.1(\mathrm{C}), 111.2(\mathrm{CH}), 127.0(\mathrm{CH}), 127.4(\mathrm{CH}), 128.6(\mathrm{CH}), 132.20$ (C), $132.2(\mathrm{CH}), 139.2(\mathrm{C}), 141.2(\mathrm{C}), 143.7(\mathrm{C}), 146.0(\mathrm{C}), 158.4(\mathrm{C})$, $162.2(\mathrm{C}), 167.1(\mathrm{C}) \mathrm{ppm}$.

Experimental Procedures and Characterization Data for 3BP-227. Benzyl methyl(3-(methyl(3-(methylamino)propyl)amino)propyl)carbamate (synthon E). A solution of $N, N$-bis[3(methylamino)propyl]methylamine $(2 \mathrm{~mL}, 11 \mathrm{mmol}, 5$ equiv.) in $\mathrm{CH}_{2} \mathrm{Cl}_{2}(15 \mathrm{~mL})$ was cooled to $-78^{\circ} \mathrm{C}$. To this solution was added dropwise a solution of benzyl chloroformate $(0.3 \mathrm{~mL}, 2.2 \mathrm{mmol}$, 1 equiv.) in $\mathrm{CH}_{2} \mathrm{Cl}_{2}(6 \mathrm{~mL})$ over $1 \mathrm{~h}$. The reaction was stirred at $78{ }^{\circ} \mathrm{C}$ for $1.5 \mathrm{~h}$ before warming to room temperature and stirred for another $15 \mathrm{~h}$. The white suspension obtained was washed twice with a solution of $\mathrm{K}_{2} \mathrm{CO}_{3} 5 \%$, twice with brine, dried over $\mathrm{MgSO}_{4}$, filtered and concentrated under vacuum. The colorless oil obtained was purified by semi-preparative RP-HPLC. A colorless oil (0.542 g, 80\%, purity: 94\%) was isolated. RP-HPLC-MS: $\mathrm{t}_{\mathrm{r}}=0.32 \mathrm{~min}, \mathrm{~m} / z$ calculated for $\mathrm{C}_{17} \mathrm{H}_{29} \mathrm{~N}_{3} \mathrm{O}_{2}[\mathrm{M}+\mathrm{H}]^{+} 308.2$, found 308.2. ${ }^{1} \mathrm{H}-\mathrm{NMR}\left(500 \mathrm{MHz}, \mathrm{CDCl}_{3}\right): \delta=1.95(\mathrm{~m}, 2 \mathrm{H}), 2.21(\mathrm{~m}, 2 \mathrm{H})$, $2.66(\mathrm{~s}, 3 \mathrm{H}), 2.76(\mathrm{~m}, 4 \mathrm{H}), 2.91(\mathrm{~s}, 3 \mathrm{H}), 3.07(\mathrm{~m}, 5 \mathrm{H}), 3.34(\mathrm{~m}, 2 \mathrm{H})$, $5.09(\mathrm{~s}, 2 \mathrm{H}), 5.76\left(\mathrm{br}, \mathrm{NH}_{2}{ }^{+}\right), 7.3-7.4(\mathrm{~m}, 5 \mathrm{H}), 9.30\left(\mathrm{br}, \mathrm{NH}^{+}\right) \mathrm{ppm} .{ }^{13} \mathrm{C}-$ $\operatorname{NMR}\left(126 \mathrm{MHz}, \mathrm{CDCl}_{3}\right): \delta=21.1\left(\mathrm{CH}_{2}\right), 22.4\left(\mathrm{CH}_{2}\right), 33.3\left(\mathrm{CH}_{3}\right), 39.8$ $\left(\mathrm{CH}_{3}\right), 45.9\left(\mathrm{CH}_{3}\right), 46.2\left(\mathrm{CH}_{2}\right), 53.1\left(\mathrm{CH}_{2}\right), 54.3\left(\mathrm{CH}_{2}\right), 67.6\left(\mathrm{CH}_{2}\right)$, 116.0 (q, TFA), $127.6(\mathrm{CH}), 128.2(\mathrm{CH}), 128.6(\mathrm{CH}), 136.4(\mathrm{C}), 157.2$ (C), 161.3 (q, TFA) ppm.

Ethyl 1-(4-((3-((3-(((benzyloxy) carbonyl)(methyl)amino)propyl)-(methyl)amino)propyl)(methyl)carbamoyl)-2-isopropylphenyl)-5-(2,6-dimethoxyphenyl)-1H-pyrazole-3-carboxylate (7). To a solution of 6 (200 $\mathrm{mg}, 0.46 \mathrm{mmol}, 1$ equiv.) in anhydrous DMF ( $2 \mathrm{~mL}$ ) was added DIPEA $(96 \mu \mathrm{L}, 0.55 \mathrm{mmol}, 1.2$ equiv.) and HATU (228 mg, $0.6 \mathrm{mmol}, 1.3$ equiv.). The solution was stirred $20 \mathrm{~min}$ at RT. A solution of benzyl methyl(3-(methyl(3-(methylamino)propyl)amino)propyl)carbamate (TFA salt) (Synthon E) (169 mg, $0.55 \mathrm{mmol}, 1.2$ equiv.) in DMF (2 mL) and DIPEA ( $289 \mu \mathrm{L}, 1.66 \mathrm{mmol}, 3.6$ equiv.) was added to the reaction mixture. The yellow solution was stirred $7 \mathrm{~h}$ at RT. The reaction mixture was evaporated to obtain a brown oil which was taken up in $\mathrm{CH}_{2} \mathrm{Cl}_{2}$ and washed four times with brine. The organic layer was dried over $\mathrm{MgSO}_{4}$, filtered and concentrated under vacuum. The oil was purified by flash-column chromatography ( $\mathrm{A}: \mathrm{CH}_{2} \mathrm{Cl}_{2}, \mathrm{~B}$ : $\mathrm{MeOH}$; with the following gradient program: $0 \%$ to $100 \%$ of $\mathrm{B}$ in $30 \mathrm{CV}$ ). An orange oil was obtained (110 mg, 33\%, purity: 98\%). RP-HPLC-MS: $\mathrm{t}_{\mathrm{r}}=4.55 \mathrm{~min}, \mathrm{~m} / \mathrm{z}$ calculated for $\mathrm{C}_{41} \mathrm{H}_{53} \mathrm{~N}_{5} \mathrm{O}_{7}[\mathrm{M}+\mathrm{H}]^{+}$728.9, found 728.4. $\mathrm{R}_{\mathrm{f}}$ $\left(\mathrm{CH}_{2} \mathrm{Cl}_{2} / \mathrm{MeOH}, 95 / 5\right)=0.23 .{ }^{1} \mathrm{H}-\mathrm{NMR}\left(500 \mathrm{MHz}, \mathrm{CDCl}_{3}\right): \delta=0.96$ (s, 6H), $1.39(\mathrm{t}, \mathrm{J}=7.1 \mathrm{~Hz}, 3 \mathrm{H}), 2.00(\mathrm{~m}, 2 \mathrm{H}), 2.06(\mathrm{~m}, 2 \mathrm{H}), 2.71(\mathrm{~m}$, $1 \mathrm{H}), 2.76(\mathrm{~m}, 2 \mathrm{H}), 2.90(\mathrm{~s}, 3 \mathrm{H}), 2.93(\mathrm{~s}, 3 \mathrm{H}), 3.12(\mathrm{~m}, 5 \mathrm{H}), 3.38(\mathrm{~m}$, $2 \mathrm{H}), 3.55(\mathrm{~m}, 2 \mathrm{H}), 3.63(\mathrm{~s}, 6 \mathrm{H}), 4.41(\mathrm{q}, \mathrm{J}=7.1 \mathrm{~Hz}, 2 \mathrm{H}), 5.10(\mathrm{~s}, 2 \mathrm{H})$, $6.44(\mathrm{~d}, \mathrm{~J}=8.3 \mathrm{~Hz}, 2 \mathrm{H}), 6.92(\mathrm{~s}, 1 \mathrm{H}), 7.2-7.4(\mathrm{~m}, 9 \mathrm{H}) \mathrm{ppm} .{ }^{13} \mathrm{C}-\mathrm{NMR}$ $\left(126 \mathrm{MHz}, \mathrm{CDCl}_{3}\right): \delta=12.5\left(\mathrm{CH}_{3}\right), 14.4\left(\mathrm{CH}_{3}\right), 21.8\left(\mathrm{CH}_{2}\right), 22.6$ $\left(\mathrm{CH}_{2}\right), 25.4(\mathrm{CH}), 27.6\left(\mathrm{CH}_{3}\right), 34.3\left(\mathrm{CH}_{3}\right), 37.7\left(\mathrm{CH}_{3}\right), 39.4\left(\mathrm{CH}_{3}\right)$, $43.5\left(\mathrm{CH}_{2}\right), 44.4,45.6\left(\mathrm{CH}_{2}\right), 50.8\left(\mathrm{CH}_{3}\right), 53.4,53.8\left(\mathrm{CH}_{2}\right), 55.5$ $\left(\mathrm{CH}_{3}\right), 60.9\left(\mathrm{CH}_{2}\right), 103.5(\mathrm{CH}), 106.5(\mathrm{C}), 111.2(\mathrm{CH}), 116.6(\mathrm{CH})$, $124.3(\mathrm{CH}), 124.9(\mathrm{CH}), 127.7(\mathrm{CH}), 128.2(\mathrm{CH}), 128.6(\mathrm{CH}), 131.6$ (C), $135.8(\mathrm{C}), 136.5(\mathrm{C}), 139.1(\mathrm{C}), 139.4(\mathrm{C}), 143.9(\mathrm{C}), 146.7$ (C), 158.3 (C), $162.8(\mathrm{C}), 175.0$ (C) ppm.

1-(4-((3-((3-(((benzyloxy) carbonyl)(methyl)amino) propyl)(methyl)amino)propyl)(methyl)carbamoyl)-2-isopropylphenyl)-5-(2,6-dimethoxyphenyl)-1H-pyrazole-3-carboxylic acid (8). To a solution of $7(0.1 \mathrm{~g}, 0.14 \mathrm{mmol}, 1$ equiv.) in dioxane $(2 \mathrm{~mL})$ was added a solution of $5 \mathrm{M} \mathrm{KOH}(0.274 \mathrm{~mL}, 1.4$ mmol, 10 equiv.). The yellow solution was stirred overnight at $40^{\circ} \mathrm{C}$. The reaction mixture was concentrated under vacuum. The residue was dissolved in water and acidified to a $\mathrm{pH}$ of 2 with $1 \mathrm{M} \mathrm{HCl}$. The aqueous phase was extracted three times with $\mathrm{CH}_{2} \mathrm{Cl}_{2}$, dried over $\mathrm{MgSO}_{4}$, filtered and concentrated under vacuum to obtain a yellow oil (91 mg, 95\%, purity: 98\%). RP-HPLCMS: $\operatorname{tr}=4.12 \mathrm{~min}, \mathrm{~m} / \mathrm{z}$ calculated for $\mathrm{C}_{39} \mathrm{H}_{49} \mathrm{~N}_{5} \mathrm{O}_{7}[\mathrm{M}+\mathrm{H}]^{+} 700.3$, found 700.3. ${ }^{1} \mathrm{H}-\mathrm{NMR}\left(500 \mathrm{MHz}, \mathrm{CDCl}_{3}\right): \delta=0.96(\mathrm{~m}, 6 \mathrm{H}), 2.03$ $(\mathrm{m}, 4 \mathrm{H}), 2.69(\mathrm{~m}, 1 \mathrm{H}), 2.77(\mathrm{~m}, 2 \mathrm{H}), 2.90(\mathrm{~s}, 3 \mathrm{H}), 2.93(\mathrm{~s}, 3 \mathrm{H}), 3.0-$ $3.2(\mathrm{~m}, 5 \mathrm{H}), 3.4(\mathrm{~m}, 2 \mathrm{H}), 3.5(\mathrm{~m}, 2 \mathrm{H}), 3.6(\mathrm{~s}, 6 \mathrm{H}), 5.11(\mathrm{~s}, 2 \mathrm{H}), 6.44$ $(\mathrm{d}, \mathrm{J}=8.3 \mathrm{~Hz}, 2 \mathrm{H}), 6.95$ (s, 1H), 7.2-7.4 (m, 9H) ppm. 
2-(5-(2,6-dimethoxyphenyl)-1-(2-isopropyl-4-(methyl-(3(methyl-(3-(methylamino)-propyl)-amino)-propyl)-carbamoyl)-phenyl)-1H-pyrazole-3-carboxamido)-adamantane-2carboxylic acid (9). To a solution of 8 (75 mg, $0.11 \mathrm{mmol}, 1$ equiv.) in DMF $(2 \mathrm{~mL})$ was added NEt $3(45 \mu \mathrm{L}, 3.21 \mathrm{mmol}, 3$ equiv.) and HATU ( $44.9 \mathrm{mg}, 0.12 \mathrm{mmol}, 1.1$ equiv.). The yellowish solution was stirred $20 \mathrm{~min}$ at RT. A solution of tert-butyl-2aminoadamantane-2-carboxylate (Synthon D) (29.7 mg, 0.12 mmol, 1.1 equiv.) in DMF ( $1 \mathrm{~mL})$ and $\mathrm{NEt}_{3}(29.8 \mu \mathrm{L}, 0.21 \mathrm{mmol}$, 2 equiv.) was added and the reaction mixture was stirred for $4 \mathrm{~h}$ at RT. The reaction mixture was concentrated under vacuum to obtain an orange oil. The intermediate was hydrogenated in EtOH $(10 \mathrm{~mL})$ and $\mathrm{Pd} / \mathrm{C} 10 \%$ under atmospheric pressure of $\mathrm{H}_{2}$. The suspension was stirred at RT for 2 days. The reaction mixture was filtered on celite, and concentrated under vacuum to give an oil. Finally, $\mathrm{CH}_{2} \mathrm{Cl}_{2}(1 \mathrm{~mL})$, TFA $(1 \mathrm{~mL})$ and $\mathrm{H}_{2} \mathrm{O}(0.1 \mathrm{~mL})$ were added. The yellow solution was stirred at RT for $1.5 \mathrm{~h}$. The reaction mixture was concentrated under vacuum and purified by semi-preparative RP-HPLC on a BetaBasic-18 column (A: $\mathrm{H}_{2} \mathrm{O} 0.1 \%$ TFA, B: MeCN $0.1 \%$ TFA with the following gradient program: $30 \%$ of B for $5 \mathrm{~min}, 30 \%$ to $60 \%$ of B in $50 \mathrm{~min}$, at a flow rate of $20 \mathrm{~mL} / \mathrm{min}$ ) to obtain the product as a white powder (2 TFA salt, $29 \mathrm{mg}, 27 \%$, purity $>99 \%$ ). RP-HPLC-MS: $\mathrm{tr}_{\mathrm{r}}=3.75 \mathrm{~min}$, $m / z$ calculated for $\mathrm{C}_{42} \mathrm{H}_{58} \mathrm{~N}_{6} \mathrm{O}_{6}[\mathrm{M}+\mathrm{H}]^{+} 743.4$, found $743.3 .{ }^{1} \mathrm{H}-$ NMR (500 MHz, CD $30 D): ~ \delta=1.10(\mathrm{~s}, 6 \mathrm{H}), 1.65-1.90(\mathrm{~m}, 9 \mathrm{H}), 2.0-$ $2.25(\mathrm{~m}, 9 \mathrm{H}), 2.64(\mathrm{~m}, 2 \mathrm{H}), 2.73(\mathrm{~s}, 3 \mathrm{H}), 2.80(\mathrm{~m}, 1 \mathrm{H}), 2.94(\mathrm{~s}, 3 \mathrm{H})$, $2.97(\mathrm{~s}, 3 \mathrm{H}), 3.12(\mathrm{~m}, 4 \mathrm{H}), 3.27(\mathrm{~m}, 2 \mathrm{H}), 3.68(\mathrm{~s}, 6 \mathrm{H}), 6.57(\mathrm{~d}, \mathrm{~J}=8.5$ $\mathrm{Hz}, 2 \mathrm{H}), 6.79(\mathrm{~s}, 1 \mathrm{H}), 7.28(\mathrm{t}, \mathrm{J}=8.5 \mathrm{~Hz}, 1 \mathrm{H}), 7.37(\mathrm{~d}, \mathrm{~J}=8.1 \mathrm{~Hz}, 1 \mathrm{H})$, 7.44 (s, 1H), 7.57 (s, 1H) ppm. ${ }^{13} \mathrm{C}-\mathrm{NMR}\left(126 \mathrm{MHz}, \mathrm{CD}_{3} \mathrm{OD}\right): \delta=$ $18.4\left(\mathrm{CH}_{3}\right), 23.1\left(\mathrm{CH}_{2}\right), 23.9\left(\mathrm{CH}_{2}\right), 29.0\left(\mathrm{CH}_{2}\right), 29.3\left(\mathrm{CH}_{2}\right), 29.9$ $(\mathrm{CH}), 34.5\left(\mathrm{CH}_{2}\right), 34.9\left(\mathrm{CH}_{2}\right), 35.0\left(\mathrm{CH}_{2}\right), 35.8\left(\mathrm{CH}_{3}\right), 39.0\left(\mathrm{CH}_{2}\right)$, $39.8\left(\mathrm{CH}_{3}\right), 41.2\left(\mathrm{CH}_{3}\right), 55.2\left(\mathrm{CH}_{3}\right), 57.1\left(\mathrm{CH}_{2}\right), 65.5\left(\mathrm{CH}_{2}\right), 106.6$ (C), $110.8(\mathrm{CH}), 126.2(\mathrm{CH}), 127.1(\mathrm{CH}), 130.2(\mathrm{CH}), 133.8(\mathrm{C})$, 138.8 (C), 148.3 (C), 160.7 (C), 176.3 (C) ppm. HRMS: m/z calculated for $\mathrm{C}_{42} \mathrm{H}_{58} \mathrm{~N}_{6} \mathrm{O}_{6}[\mathrm{M}+\mathrm{H}]^{+} 743.44972$, found $743.44937 ; \mathrm{m} / \mathrm{z}$ calculated for $[\mathrm{M}+2 \mathrm{H}]^{2+} 372.22883$, found 372.22752 .

2-((1-(4-((3-)(3-(DOTA-methylamino)-propyl)methylamino)-propyl)-methyl-carbamoyl)-2-isopropylphenyl)-5-(2,6-dimethoxyphenyl)-1H-pyrazole-3-carbonyl)-amino)-adamantane-2-carboxylic acid (3BP-227). To a solution of 9 (TFA salt) (17 mg, $19.8 \mu \mathrm{mol}, 1$ equiv.) in anhydrous DMF $(1 \mathrm{~mL})$ and DIPEA $(10.3 \mu \mathrm{L}, 59.4 \mu \mathrm{mol}, 3$ equiv. $)$ was added a solution of DOTA-NHS (30.16 mg, $39.6 \mu \mathrm{mol}, 2$ equiv.) in anhydrous DMF $(1 \mathrm{~mL})$ with DIPEA $(41.5 \mu \mathrm{L}, 0.24 \mathrm{mmol}, 12$ equiv.). The reaction mixture was stirred overnight at RT. The reaction medium was concentrated under vacuum and the resulting oil was purified on a BetaBasic-18 column $\left(\mathrm{A}: \mathrm{H}_{2} \mathrm{O} 0.1 \%\right.$ TFA, B: MeCN $0.1 \%$ TFA with the following gradient program: $30 \%$ of $\mathrm{B}$ for $5 \mathrm{~min}, 30 \%$ to $60 \%$ of $\mathrm{B}$ in $50 \mathrm{~min}$, at a flow rate of $20 \mathrm{~mL} / \mathrm{min}$ ). The product 3BP-227 was obtained as a white powder (4 TFA salt, $22.8 \mathrm{mg}$, 73\%, purity: 99\%). RP-HPLC-MS: $\mathrm{t}_{\mathrm{r}}=$ $3.88 \mathrm{~min}, \mathrm{~m} / z$ calculated for $\mathrm{C}_{58} \mathrm{H}_{84} \mathrm{~N}_{10} \mathrm{O}_{13}[\mathrm{M}+\mathrm{H}]^{+} 1129.6$, found 1129.8. HRMS: $m / z$ calculated for $\mathrm{C}_{58} \mathrm{H}_{84} \mathrm{~N}_{10} \mathrm{O}_{13} \quad[\mathrm{M}+\mathrm{H}]^{+}$ 1129.62987, found 1129.63250.; $\mathrm{m} / \mathrm{z}$ calculated for $[\mathrm{M}+2 \mathrm{H}]^{2+}$ 565.30309, found 565.31998.

Experimental Procedures and Characterization Data for synthon C. Tert-butyl (3-((2-nitrophenyl)sulfonamido)propyl)carbamate (10). A solution of $N$-Boc-1,3-propanediamine $(0.5 \mathrm{~g}$, $2.87 \mathrm{mmol}, 1$ equiv.), $\mathrm{CH}_{2} \mathrm{Cl}_{2}(7 \mathrm{~mL})$ and triethylamine $(0.4 \mathrm{~mL}$,
$2.87 \mathrm{mmol}, 1$ equiv.) was cooled in an ice-water bath. 2-nitrobenzenesulfonyl chloride ( $0.636 \mathrm{~g}, 2.87 \mathrm{mmol}, 1$ equiv.) was added over a period of $5 \mathrm{~min}$. After $5 \mathrm{~min}$, the ice bath was removed and the reaction mixture was allowed to warm to room temperature and stirred for $15 \mathrm{~min}$. The reaction mixture was extracted with $\mathrm{CH}_{2} \mathrm{Cl}_{2}$ and washed three times with a solution of citric acid $(\mathrm{pH}=3)$. The organic layer was dried over $\mathrm{MgSO}_{4}$, filtered and concentrated under vacuum. The yellowish oil was purified by flash-column chromatography (A: $\mathrm{CH}_{2} \mathrm{Cl}_{2}, \mathrm{~B}: \mathrm{CH}_{2} \mathrm{Cl}_{2} / \mathrm{MeOH} 9: 1$; with the following gradient program: $100 \%$ to $0 \%$ of $\mathrm{A}$ in $20 \mathrm{CV}$ ). An oil, which crystallizes, was obtained (0.942 g, 90\%, purity: 98\%). RP-HPLC-MS: $\mathrm{t}_{\mathrm{r}}=4.46 \mathrm{~min}, \mathrm{~m} / z$ calculated for $\mathrm{C}_{14} \mathrm{H}_{21} \mathrm{~N}_{3} \mathrm{O}_{6} \mathrm{~S}$ $[\mathrm{M}+\mathrm{H}]^{+}$360.1, found $260.1[\mathrm{M}-\mathrm{Boc}+\mathrm{H}]^{+}$. $\mathrm{Rf}\left(\mathrm{CH}_{2} \mathrm{Cl}_{2} / \mathrm{MeOH}, 9 / 1\right)=$ 0.68. ${ }^{1} \mathrm{H}-\mathrm{NMR}\left(500 \mathrm{MHz}, \mathrm{CDCl}_{3}\right): \delta=1.42$ (s, 9H), 1.69 (quint, $\mathrm{J}=6.4 \mathrm{~Hz}, 2 \mathrm{H}), 3.15$ (q, J=6.4 Hz, 2H), 3.21 (q, J=6.4 Hz, 2H), 4.67 (br, 1H), 5.87 (br, 1H), $7.72(\mathrm{~m}, 2 \mathrm{H}), 7.84(\mathrm{~m}, 1 \mathrm{H}), 8.16(\mathrm{~m}, 1 \mathrm{H})$ ppm; ${ }^{13} \mathrm{C}-\mathrm{NMR}\left(126 \mathrm{MHz}, \mathrm{CDCl}_{3}\right): \delta=28.4\left(\mathrm{CH}_{3}\right), 30.6\left(\mathrm{CH}_{2}\right), 37.2$ $\left(\mathrm{CH}_{2}\right), 40.8\left(\mathrm{CH}_{2}\right), 125.3(\mathrm{CH}), 130.9(\mathrm{CH}), 132.7(\mathrm{CH}), 133.4(\mathrm{CH})$ ppm. (Note: three quaternary carbons not detected).

Tert-butyl (3-((N-(3-(dimethylamino)propyl)-2-nitrophenyl)sulfonamido)propyl)carbamate (11). To a solution of tert-butyl (3-((2-nitrophenyl)sulfonamido)propyl)carbamate (10) $(0.94 \mathrm{~g}, 2.6 \mathrm{mmol}, 1$ equiv.) in DMF $(10 \mathrm{~mL})$ was added $\mathrm{K}_{2} \mathrm{CO}_{3}$ (1.08 g, $7.8 \mathrm{mmol}, 3$ equiv.). To the stirred suspension was added 3-dimethylamino-1-propyl hydrochloride $(0.45 \mathrm{~g}, 2.86$ mmol, 1.1 equiv.) over a period of $5 \mathrm{~min}$. The resulting suspension was heated to $60{ }^{\circ} \mathrm{C}$ overnight. The reaction mixture was cooled to RT, diluted with water $(50 \mathrm{~mL})$, and extracted three times with $\mathrm{CH}_{2} \mathrm{Cl}_{2}$. The organic layers were combined, washed with brine, dried over $\mathrm{MgSO}_{4}$, filtered and concentrated under vacuum. A yellowish oil (1.15 g, 99\%, purity: 96\%) was obtained. RP-HPLC-MS: $\operatorname{tr}_{r}=3.6 \mathrm{~min}, \mathrm{~m} / \mathrm{z}$ calculated for $\mathrm{C}_{19} \mathrm{H}_{32} \mathrm{~N}_{4} \mathrm{O}_{6} \mathrm{~S}$ $[\mathrm{M}+\mathrm{H}]^{+}$445.2, found 445.2. ${ }^{1} \mathrm{H}-\mathrm{NMR}\left(500 \mathrm{MHz}, \mathrm{CDCl}_{3}\right): \delta=1.41$ $(\mathrm{s}, 9 \mathrm{H}), 1.66$ (quint, J=6.9 Hz, 2H), 1.74 (quint, J=6.9 Hz, 2H), 2.13 (s, 6H), $2.19(\mathrm{t}, \mathrm{J}=7.0 \mathrm{~Hz}, 2 \mathrm{H}), 3.14(\mathrm{~m}, 2 \mathrm{H}), 3.32(\mathrm{t}, \mathrm{J}=7.4 \mathrm{~Hz}, 2 \mathrm{H})$, $3.36(\mathrm{t}, \mathrm{J}=7.4 \mathrm{~Hz}, 2 \mathrm{H}), 4.91(\mathrm{br}, 1 \mathrm{H}), 7.62(\mathrm{~m}, 2 \mathrm{H}), 7.98(\mathrm{~m}, 2 \mathrm{H})$ ppm; ${ }^{13} \mathrm{C}-\mathrm{NMR}\left(126 \mathrm{MHz}, \mathrm{CDCl}_{3}\right): \delta=26.5\left(\mathrm{CH}_{2}\right), 28.4\left(\mathrm{CH}_{3}\right), 37.3$ $\left(\mathrm{CH}_{2}\right), 45.3\left(\mathrm{CH}_{2}\right), 45.4\left(\mathrm{CH}_{3}\right), 45.9\left(\mathrm{CH}_{2}\right), 56.5\left(\mathrm{CH}_{2}\right), 79.2(\mathrm{C})$, $124.2(\mathrm{CH}), 130.6(\mathrm{CH}), 131.7(\mathrm{CH}), 133.4(\mathrm{CH}), 133.5(\mathrm{C}), 148.1$ (C), 156.0 (C) ppm.

Tert-butyl (3-((3-(dimethylamino)propyl)amino)propyl)-carbamate (synthon $\mathrm{C})$. To a solution of tert-butyl (3-((N-(3-(dimethylamino)propyl)-2-nitrophenyl)sulfonamido)propyl)carbamate (11) (1.1 g, 2.5 mmol, 1 equiv.) in DMF (10 mL) was added cesium carbonate ( $3.3 \mathrm{~g}, 10 \mathrm{mmol}, 4$ equiv.). Thiophenol (0.51 $\mathrm{mL}, 5 \mathrm{mmol}$, 2 equiv.) was then added to the suspension and the reaction mixture was stirred at $40{ }^{\circ} \mathrm{C}$ for $5 \mathrm{~h}$. The reaction medium was extracted in a solution of citric acid $(\mathrm{pH}=3)$ and washed three times with $\mathrm{CH}_{2} \mathrm{Cl}_{2}$. After basification with a solution of $\mathrm{K}_{2} \mathrm{CO}_{3}$, the compound was extracted four times with $\mathrm{CH}_{2} \mathrm{Cl}_{2}$. The organic layers were combined, dried over $\mathrm{MgSO}_{4}$, filtered and concentrated under vacuum. The yellowish oil was purified by semi-preparative HPLC on a BetaBasic-18 column (A: $\mathrm{H}_{2} \mathrm{O} 0.1 \%$ TFA, $\mathrm{B}$ : MeCN 0.1\% TFA; with the following gradient program: $0 \%$ of B for $10 \mathrm{~min}, 0 \%$ to $40 \%$ of B in $50 \mathrm{~min}$, at a flow rate of $20 \mathrm{~mL} / \mathrm{min}$ ) to obtain a white solid as 3 TFA salt $(0.681 \mathrm{~g}, 56 \%)$. RP-HPLC-MS: $\mathrm{tr}_{\mathrm{r}}=$ injection peak, $\mathrm{m} / \mathrm{z}$ calculated for $\mathrm{C}_{13} \mathrm{H}_{29} \mathrm{~N}_{3} \mathrm{O}_{2}[\mathrm{M}+\mathrm{H}]^{+}$260.2, found 260.3. ${ }^{1} \mathrm{H}-\mathrm{NMR}(500 \mathrm{MHz}$, DMSO-d 6 ): $\delta=1.38(\mathrm{~s}, 9 \mathrm{H}), 1.70$ (quint, J=7.8 Hz, 2H), 1.95 (quint, $\mathrm{J}=7.8 \mathrm{~Hz}, 2 \mathrm{H}), 2.78(\mathrm{~s}, 6 \mathrm{H}), 2.89(\mathrm{~m}, 2 \mathrm{H}), 2.96(\mathrm{~m}, 2 \mathrm{H}), 2.99(\mathrm{~m}$, 
2H), $3.11(\mathrm{~m}, 2 \mathrm{H}) \mathrm{ppm} ;{ }^{13} \mathrm{C}-\mathrm{NMR}$ (126 MHz, DMSO-d $): \delta=21.3$ $\left(\mathrm{CH}_{2}\right), 26.7\left(\mathrm{CH}_{2}\right), 28.8\left(\mathrm{CH}_{3}\right), 37.5\left(\mathrm{CH}_{2}\right), 42.7\left(\mathrm{CH}_{2}\right), 44.3\left(\mathrm{CH}_{3}\right)$, $45.2\left(\mathrm{CH}_{2}\right), 54.2\left(\mathrm{CH}_{2}\right), 78.3(\mathrm{C}) \mathrm{ppm}$. (Note: one quaternary carbon not detected).

Experimental Procedures and Characterization Data for 12. Ethyl 1-(4-((3-((tert-butoxycarbonyl)amino)propyl)(3-(dimethylamino)propyl)carbamoyl)-2-isopropylphenyl)-5-(2,6-dimethoxyphenyl)-1H-pyrazole-3-carboxylate (12). To a solution of 11 (0.4 g, $0.91 \mathrm{mmol}, 1$ equiv.) in anhydrous DMF (5 mL) was added DIPEA (0.174 mL, $1.0 \mathrm{mmol}, 1.1$ equiv.) and HATU (0.38 $\mathrm{g}, 1.0 \mathrm{mmol}, 1.1$ equiv.). The orange solution was stirred $10 \mathrm{~min}$ at RT. A solution of tert-butyl (3-((3-(dimethylamino)propyl)amino)propyl)carbamate (2 TFA) (Synthon C) (0.487 g, 1.0 mmol, 1.1 equiv.) in DMF $(5 \mathrm{~mL})$ and DIPEA $(0.522 \mathrm{~mL}, 3.0$ mmol, 3.3 equiv.) was added to the reaction mixture. The orange solution was stirred for $6 \mathrm{~h}$ at RT. The reaction mixture was evaporated to obtain an orange oil which was taken up in $\mathrm{CH}_{2} \mathrm{Cl}_{2}$ and washed twice with brine. The organic layer was dried over $\mathrm{MgSO}_{4}$, filtered and concentrated under vacuum. An orange oil was obtained, which was purified by flash-column chromatography (A: $\mathrm{CH}_{2} \mathrm{Cl}_{2}, \mathrm{~B}$ : $\mathrm{MeOH}$; with the following gradient program: $100 \%$ to $70 \%$ of $\mathrm{B}$ in $30 \mathrm{CV})$. The product was isolated as an orange oil (0.602 g, 97\%, purity: 96\%). RP-HPLC-MS: $\mathrm{t}_{\mathrm{r}}=4.27$ min, $m / z$ calculated for $\mathrm{C}_{37} \mathrm{H}_{53} \mathrm{~N}_{5} \mathrm{O}_{7}[\mathrm{M}+\mathrm{H}]^{+} 680.4$, found 680.5 . ${ }^{1} \mathrm{H}-\mathrm{NMR}\left(500 \mathrm{MHz}, \mathrm{CDCl}_{3}\right): \delta=0.98(\mathrm{~s}, 6 \mathrm{H}), 1.39(\mathrm{~s}, 9 \mathrm{H}), 1.41(\mathrm{t}$, $\mathrm{J}=7.1 \mathrm{~Hz}, 3 \mathrm{H}), 1.68(\mathrm{~m}, 2 \mathrm{H}), 1.81(\mathrm{~m}, 1 \mathrm{H}), 2.04(\mathrm{~m}, 1 \mathrm{H}), 2.19(\mathrm{~m}$, $2 \mathrm{H}), 2.72(\mathrm{~m}, 1 \mathrm{H}), 2.79(\mathrm{~s}, 6 \mathrm{H}), 3.1-3.3(\mathrm{~m}, 4 \mathrm{H}), 3.55(\mathrm{~m}, 2 \mathrm{H}), 3.65$ (s, 6H), $4.42(\mathrm{q}, \mathrm{J}=7.1 \mathrm{~Hz}, 2 \mathrm{H}), 4.81(\mathrm{br}, 1 \mathrm{H}), 6.46(\mathrm{~d}, \mathrm{~J}=8.4 \mathrm{~Hz}, 2 \mathrm{H})$, $6.92(\mathrm{~s}, 1 \mathrm{H}), 7.16(\mathrm{~d}, \mathrm{~J}=7.8 \mathrm{~Hz}, 1 \mathrm{H}), 7.2-7.25(\mathrm{~m}, 2 \mathrm{H}), 7.39$ (d, J=7.8 $\mathrm{Hz}, 1 \mathrm{H}) \mathrm{ppm} .{ }^{13} \mathrm{C}-\mathrm{NMR}\left(126 \mathrm{MHz}, \mathrm{CDCl}_{3}\right): \delta=12.2\left(\mathrm{CH}_{3}\right), 14.5$ $\left(\mathrm{CH}_{3}\right), 17.4(\mathrm{CH}), 18.6\left(\mathrm{CH}_{2}\right), 27.6\left(\mathrm{CH}_{3}\right), 28.4\left(\mathrm{CH}_{3}\right), 42.3\left(\mathrm{CH}_{2}\right)$, $43.1\left(\mathrm{CH}_{3}\right), 43.6\left(\mathrm{CH}_{3}\right), 54.2\left(\mathrm{CH}_{3}\right), 55.5\left(\mathrm{CH}_{2}\right), 60.9\left(\mathrm{CH}_{2}\right), 81.5$ $(\mathrm{CH}), 103.5(\mathrm{CH}), 111.1(\mathrm{CH}), 124.2(\mathrm{CH}), 128.8(\mathrm{CH}), 131.6(\mathrm{CH})$, $133.9(\mathrm{CH}), 158.3(\mathrm{C}), 162.7$ (C) ppm.

Experimental Procedures and Characterization Data for synthon D. 2-aminoadamantane-2-carbonitrile (13). A mixture of 2-adamantanone ( $2 \mathrm{~g}, 13.3 \mathrm{mmol}, 1$ equiv.), $\mathrm{NaCN}$ (0.784 g, 16 mmol, 1.2 equiv.), aqueous ammonia $25 \%$ solution $(2.4 \mathrm{~mL})$ and ammonium chloride $(1.423 \mathrm{~g}, 26.6 \mathrm{mmol}$, 2 equiv.) was dissolved in water $(12 \mathrm{~mL})$ and $\mathrm{EtOH}(24 \mathrm{~mL})$. The resulting solution was stirred at $50{ }^{\circ} \mathrm{C}$ overnight. The solution was cooled to RT, extracted with $\mathrm{Et}_{2} \mathrm{O}(120 \mathrm{~mL})$ and concentrated. The white solid obtained was then purified on a silica plug (heptane/EtOAc 7:3). A white powder $(2.16 \mathrm{~g}, 92 \%)$ was obtained. RP-HPLC-MS: $t_{r}=$ $4.9 \mathrm{~min}$., $\mathrm{m} / \mathrm{z}$ calculated for $\mathrm{C}_{11} \mathrm{H}_{16} \mathrm{~N}_{2}[\mathrm{M}+\mathrm{H}+\mathrm{MeCN}]^{+} 218.1$, found 218.1. $\mathrm{R}_{\mathrm{f}}($ heptane/EtOAc, $7 / 3)=0.4 .{ }^{1} \mathrm{H}-\mathrm{NMR}\left(500 \mathrm{MHz}, \mathrm{CDCl}_{3}\right)$ : $\delta=1.54(\mathrm{~m}, 1 \mathrm{H}), 1.70(\mathrm{~m}, 1 \mathrm{H}), 1.72(\mathrm{~m}, 1 \mathrm{H}), 1.76(\mathrm{~m}, 1 \mathrm{H}), 1.84(\mathrm{~m}$, $1 \mathrm{H}), 1.87(\mathrm{~m}, 1 \mathrm{H}), 1.90(\mathrm{~m}, 1 \mathrm{H}), 1.93(\mathrm{~m}, 1 \mathrm{H}), 1.96(\mathrm{~m}, 1 \mathrm{H}), 1.98$ $(\mathrm{m}, 1 \mathrm{H}), 2.06(\mathrm{~m}, 1 \mathrm{H}), 2.14(\mathrm{~m}, 1 \mathrm{H}), 2.23(\mathrm{~d}, 1 \mathrm{H}), 2.51(\mathrm{~m}, 1 \mathrm{H})$ ppm; ${ }^{13} \mathrm{C}-\mathrm{NMR}\left(126 \mathrm{MHz}, \mathrm{CDCl}_{3}\right): \delta=26.5(\mathrm{CH}), 26.8(\mathrm{CH}), 27.5$ $(\mathrm{CH}), 30.3\left(\mathrm{CH}_{2}\right), 35.0\left(\mathrm{CH}_{2}\right), 36.4\left(\mathrm{CH}_{2}\right), 36.6(\mathrm{CH}), 37.6\left(\mathrm{CH}_{2}\right)$, $39.3\left(\mathrm{CH}_{2}\right), 56.4(\mathrm{C}), 125.5(\mathrm{C})$ ppm. mp: $186^{\circ} \mathrm{C}$.

$\mathrm{N}$-(2-cyanoadamantan-2-yl)benzamide (14). To a solution of 2-aminoadamantane-2-carbonitrile (13) (1.5 g, $8.5 \mathrm{mmol}, 1$ equiv.) in THF (15 mL) was added a solution of $\mathrm{K}_{2} \mathrm{CO}_{3}(1.78 \mathrm{~g}$, $12.9 \mathrm{mmol}, 1.52$ equiv.) in water $(15 \mathrm{~mL})$. To the resulting solution was added dropwise, over $30 \mathrm{~min}$, a solution of benzoyl chloride (1.48 mL, $12.8 \mathrm{mmol}, 1.5$ equiv.) in THF (15 mL) with vigorous stirring at RT. After $5 \mathrm{~min}$, a white precipitate began to form. After a further $2 \mathrm{~h}$, the white solid was isolated by filtration and dried under vacuum. The solid was purified on a silica plug $\left(\mathrm{CH}_{2} \mathrm{Cl}_{2} / \mathrm{MeOH} 95: 5\right)$ to obtain a white powder $(1.64 \mathrm{~g}$, 69\%, purity: 90\%). RP-HPLC-MS: $\mathrm{t}_{\mathrm{r}}=4.79 \mathrm{~min} ., \mathrm{m} / \mathrm{z}$ calculated for $\mathrm{C}_{18} \mathrm{H}_{20} \mathrm{~N}_{2} \mathrm{O}[\mathrm{M}+\mathrm{H}]^{+}$281.2, found 281.1. Rf (heptane/EtOAc, $\left.7 / 3\right)=$ 0.31. ${ }^{1} \mathrm{H}-\mathrm{NMR}\left(500 \mathrm{MHz}, \mathrm{CDCl}_{3}\right): \delta=1.76(\mathrm{~m}, 3 \mathrm{H}), 1.85-2.02(\mathrm{~m}$, $8 \mathrm{H}), 2.05(\mathrm{~m}, 1 \mathrm{H}), 2.32(\mathrm{~d}, 1 \mathrm{H}), 2.65(\mathrm{~m}, 1 \mathrm{H}), 6.12(\mathrm{br}, 1 \mathrm{H}), 7.43$ $(\mathrm{td}, \mathrm{J}=8.5,1.7 \mathrm{~Hz}, 2 \mathrm{H}), 7.52(\mathrm{tt}, \mathrm{J}=8.5,1.7 \mathrm{~Hz}, 1 \mathrm{H}), 7.77(\mathrm{dt}, \mathrm{J}=8.5$, $1.7 \mathrm{~Hz}, 2 \mathrm{H}) \mathrm{ppm} ;{ }^{13} \mathrm{C}-\mathrm{NMR}\left(126 \mathrm{MHz}, \mathrm{CDCl}_{3}\right): \delta=26.2(\mathrm{CH}), 26.5$ $(\mathrm{CH}), 27.6\left(\mathrm{CH}_{2}\right), 31.5\left(\mathrm{CH}_{2}\right), 33.9(\mathrm{CH}), 34.2\left(\mathrm{CH}_{2}\right), 37.3\left(\mathrm{CH}_{2}\right)$, $39.4\left(\mathrm{CH}_{2}\right), 47.1(\mathrm{CH}), 57.3(\mathrm{C}), 120.2(\mathrm{C}), 127.2(\mathrm{CH}), 128.9(\mathrm{CH})$, $132.3(\mathrm{CH}), 134.0(\mathrm{C}), 166.6(\mathrm{C}) \mathrm{ppm} . \mathrm{mp}: 250^{\circ} \mathrm{C}$.

2-aminoadamantane-2-carboxylic acid hydrochloride (15). To N-(2-cyanoadamantan-2-yl)benzamide (14) (1 g, $3.6 \mathrm{mmol}, 1$ equiv.) was added acetic acid $(18 \mathrm{~mL})$, concentrated $\mathrm{HCl}(5 \mathrm{~mL})$ and water $(3 \mathrm{~mL})$. The white suspension was then heated to reflux for 5 days. The reaction mixture was concentrated under vacuum to obtain a white solid which was triturated twice in hot $\mathrm{Et}_{2} \mathrm{O}(40 \mathrm{~mL})$ and twice in hot $\mathrm{MeCN}(25 \mathrm{~mL})$. A white powder $(0.768 \mathrm{~g}, 92 \%)$ was obtained. RP-HPLC-MS: $\mathrm{t}_{\mathrm{r}}=0.5 \mathrm{~min}, \mathrm{~m} / \mathrm{z}$ calculated for $\mathrm{C}_{11} \mathrm{H}_{17} \mathrm{NO}_{2}[\mathrm{M}+\mathrm{H}]^{+}$196.1, found 196.3. ${ }^{1} \mathrm{H}-\mathrm{NMR}(500$ MHz, DMSO-d 6$): \delta=1.6-2.2(\mathrm{~m}, 14 \mathrm{H}), 8.59(\mathrm{br}, 2 \mathrm{H}), 13.84(\mathrm{br}, 1 \mathrm{H})$ ppm; ${ }^{13} \mathrm{C}-\mathrm{NMR}\left(126 \mathrm{MHz}, \mathrm{DMSO}-\mathrm{d}_{6}\right): \delta=26.2(\mathrm{CH}), 31.2\left(\mathrm{CH}_{2}\right)$, $32.2(\mathrm{CH}), 34.4\left(\mathrm{CH}_{2}\right), 37.5\left(\mathrm{CH}_{2}\right), 63.9(\mathrm{C}), 171.4(\mathrm{C})$ ppm. mp: $271^{\circ} \mathrm{C}$.

Tert-butyl-2-aminoadamantane-2-carboxylate (synthon D). A suspension of 2-aminoadamantane-2-carboxylic acid hydrochloride (15) $(0.7 \mathrm{~g}, 3.0 \mathrm{mmol}, 1$ equiv. $)$ in tert-butyl acetate (25 $\mathrm{mL})$ was cooled to $0{ }^{\circ} \mathrm{C}$. $\mathrm{HClO}_{4}(0.42 \mathrm{~mL}, 4.8 \mathrm{mmol}, 1.6$ equiv. $)$ was added dropwise and the reaction mixture was stirred at RT overnight. $2 \mathrm{M} \mathrm{NaOH}(40 \mathrm{~mL})$ was added slowly at $0{ }^{\circ} \mathrm{C}$ to quench the reaction until the $\mathrm{pH}$ reached 9-10. The mixture was then extracted with EtOAc $(4 \times 100 \mathrm{~mL})$ and washed with brine. After being dried with $\mathrm{MgSO}_{4}$, the organic layer was filtered and concentrated under vacuum to obtain a white solid, which was purified by flash-column chromatography (A: $\mathrm{CH}_{2} \mathrm{Cl}_{2}$, B: $\mathrm{CH}_{2} \mathrm{Cl}_{2} / \mathrm{MeOH}$ 9:1; with the following gradient program: $0 \%$ to $20 \%$ of B in $10 \mathrm{CV}, 20 \%$ of B for $10 \mathrm{CV})$. A white solid $(0.3 \mathrm{~g}, 40 \%$, purity: 96\%) was obtained. RP-HPLC-MS: $\mathrm{t}_{\mathrm{r}}=3.7 \mathrm{~min} ., \mathrm{m} / \mathrm{z}$ calculated for $\mathrm{C}_{15} \mathrm{H}_{25} \mathrm{NO}_{2}[\mathrm{M}+\mathrm{H}]^{+}$252.2, found 252.2. $\mathrm{R}_{\mathrm{f}}$ $\left(\mathrm{CH}_{2} \mathrm{Cl}_{2} / \mathrm{MeOH}, 98 / 2\right)=0.34 .{ }^{1} \mathrm{H}-\mathrm{NMR}\left(500 \mathrm{MHz}, \mathrm{CDCl}_{3}\right): \delta=1.35$ $(\mathrm{m}, 2 \mathrm{H}), 1.40(\mathrm{~s}, 9 \mathrm{H}), 1.47(\mathrm{~m}, 2 \mathrm{H}), 1.60(\mathrm{~m}, 2 \mathrm{H}), 1.69(\mathrm{~m}, 6 \mathrm{H}), 1.97$ (m, 2H), $2.15(\mathrm{~m}, 2 \mathrm{H}) \mathrm{ppm} ;{ }^{13} \mathrm{C}-\mathrm{NMR}\left(126 \mathrm{MHz}, \mathrm{CDCl}_{3}\right): \delta=26.9$ $(\mathrm{CH}), 27.2\left(\mathrm{CH}_{3}\right), 27.9(\mathrm{CH}), 32.0\left(\mathrm{CH}_{2}\right), 34.1(\mathrm{CH}), 35.1\left(\mathrm{CH}_{2}\right), 37.8$ $\left(\mathrm{CH}_{2}\right), 61.8(\mathrm{C}), 79.9(\mathrm{C}), 176.0(\mathrm{C}) \mathrm{ppm} . \mathrm{mp}: 99^{\circ} \mathrm{C}$.

Experimental Procedures and Characterization Data for precursor 16. 2-((1-(4-((3-aminopropyl)-(3-dimethylaminopropyl)carbamoyl)-2-isopropylphenyl)-5-(2,6-dimethoxyphenyl)-1Hpyrazole-3-carbonyl)-amino)-adamantane-2-carboxylic acid (16). To a solution of $\mathbf{1 2}(0.602 \mathrm{~g}, 0.86 \mathrm{mmol}, 1$ equiv.) in dioxane $(9 \mathrm{~mL})$ was added a solution of $5 \mathrm{M} \mathrm{KOH}(0.886 \mathrm{~mL}, 4.43 \mathrm{mmol}$, 5 equiv.). The yellow solution was stirred overnight at RT. The reaction mixture was concentrated under vacuum. The residue was taken up in water and washed three times with $\mathrm{Et}_{2} \mathrm{O}$. The aqueous phase was acidified to $\mathrm{pH} 3-4$ (precipitation) with a solution of $1 \mathrm{M} \mathrm{HCl}$ and evaporated. $\mathrm{EtOH}$ was added to the residue and $\mathrm{KCl}$ was filtered off. The solution was concentrated under vacuum to obtain an orange oil. DMF $(15 \mathrm{~mL}), \mathrm{NEt} 3(0.46 \mathrm{~mL}$, $3.3 \mathrm{mmol}, 3$ equiv.) and HATU ( $0.46 \mathrm{~g}, 1.2 \mathrm{mmol}, 1.1$ equiv.) were added. The yellowish solution was stirred for $15 \mathrm{~min}$ at RT. A 
solution of tert-butyl-2-aminoadamantane-2-carboxylate (Synthon D) (0.302 g, $1.2 \mathrm{mmol}, 1.1$ equiv.) in DMF (5 mL) and $\mathrm{NEt}_{3}(0.31 \mathrm{~mL}, 2.2 \mathrm{mmol}, 2$ equiv.) was added to the reaction mixture and stirred for $4 \mathrm{~h}$ at RT. The reaction mixture was concentrated under vacuum to obtain an orange oil. Finally, $\mathrm{CH}_{2} \mathrm{Cl}_{2}$ (5 mL), TFA $(5 \mathrm{~mL})$ and $\mathrm{H}_{2} \mathrm{O}(0.5 \mathrm{~mL})$ were added. The yellow solution was stirred at RT for $1.5 \mathrm{~h}$. The reaction mixture was concentrated under vacuum and purified by semi-preparative HPLC on a BetaBasic-18 column (A: $\mathrm{H}_{2} \mathrm{O} 0.1 \%$ TFA, B: MeCN $0.1 \%$ TFA with the following gradient program: $20 \%$ of $b$ for 5 $\mathrm{min}, 20 \%$ to $60 \%$ of B in $50 \mathrm{~min}$, at a flow rate of $20 \mathrm{~mL} / \mathrm{min}$ ) to obtain 16 as a white powder (2 TFA salt, $0.456 \mathrm{~g}, 55 \%$, purity: 99\%). RP-HPLC-MS: $\mathrm{t}_{\mathrm{r}}=3.66 \mathrm{~min}, \mathrm{~m} / z$ calculated for $\mathrm{C}_{41} \mathrm{H}_{56} \mathrm{~N}_{6} \mathrm{O}_{6}$ $[\mathrm{M}+\mathrm{H}]^{+}$729.4, found 729.3. ${ }^{1} \mathrm{H}-\mathrm{NMR}\left(500 \mathrm{MHz}, \mathrm{CDCl}_{3}\right): \delta=0.97$ $(\mathrm{s}, 6 \mathrm{H}), 1.49(\mathrm{~m}, 2 \mathrm{H}), 1.63(\mathrm{~m}, 4 \mathrm{H}), 1.67-1.80(\mathrm{~m}, 4 \mathrm{H}), 1.90(\mathrm{~m}, 2 \mathrm{H})$, $1.98(\mathrm{~m}, 2 \mathrm{H}), 2.11(\mathrm{~m}, 4 \mathrm{H}), 2.51(\mathrm{~m}, 2 \mathrm{H}), 2.6-2.7(\mathrm{~m}, 2 \mathrm{H}), 2.72(\mathrm{~s}$, $3 \mathrm{H}), 2.78(\mathrm{~m}, 1 \mathrm{H}), 2.91(\mathrm{~s}, 3 \mathrm{H}), 3.09(\mathrm{~m}, 1 \mathrm{H}), 3.2-3.35(\mathrm{~m}, 3 \mathrm{H}), 3.57$ $(\mathrm{s}, 6 \mathrm{H}), 6.6(\mathrm{~d}, \mathrm{~J}=8.4 \mathrm{~Hz}, 2 \mathrm{H}), 6.87(\mathrm{~s}, 1 \mathrm{H}), 7.2-7.4(\mathrm{~m}, 4 \mathrm{H}) \mathrm{ppm}$. ${ }^{13} \mathrm{C}-\mathrm{NMR}\left(126 \mathrm{MHz}, \mathrm{CDCl}_{3}\right): \delta=11.3\left(\mathrm{CH}_{3}\right), 26.4\left(\mathrm{CH}_{3}\right), 27.6$ $\left(\mathrm{CH}_{3}\right), 33.4\left(\mathrm{CH}_{2}\right), 36.7\left(\mathrm{CH}_{2}\right), 37.0\left(\mathrm{CH}_{2}\right), 42.6\left(\mathrm{CH}_{3}\right), 42.8\left(\mathrm{CH}_{3}\right)$, $54.5\left(\mathrm{CH}_{2}\right), 55.2\left(\mathrm{CH}_{2}\right), 55.6\left(\mathrm{CH}_{3}\right), 63.6\left(\mathrm{CH}_{2}\right), 104.0(\mathrm{CH}), 105.6$ (C), $109.0(\mathrm{CH}), 123.5(\mathrm{CH}), 124.3(\mathrm{CH}), 129.9(\mathrm{CH}), 137.8(\mathrm{C})$, 158.1 (C), 159.4 (C) ppm. HRMS: $m / z$ calculated for $\mathrm{C}_{41} \mathrm{H}_{56} \mathrm{~N}_{6} \mathrm{O}_{6}$ $[\mathrm{M}+\mathrm{H}]^{+} 729.43407$, found $729.43468 ; \mathrm{m} / \mathrm{z}$ calculated for $[\mathrm{M}+\mathrm{Na}]^{+}$ 751.41590 , found 751.41378 .

General procedure for the coupling of the chelating agent. To a solution of 16 (1 equiv.) in anhydrous DMF $(0.5 \mathrm{~mL})$ and DIPEA (2 equiv.), was added a solution of the chelating agent (1.5 equiv.) in anhydrous DMF $(0.5 \mathrm{~mL})$ with DIPEA (6-9 equiv. depending of the chelator). The reaction mixture was stirred for 2-4 h at RT until completion. The reaction medium was concentrated under vacuum and the oil was purified on a semi-preparative column.

2-((1-(4-((3-DOTA-aminopropyl)-(3-dimethylaminopropyl)carbamoyl)-2-isopropylphenyl)-5-(2,6-dimethoxyphenyl)-1Hpyrazole-3-carbonyl-amino)-adamantane-2-carboxylic acid (3BP-228). Chelator: DOTA-NHS, Reaction time: $2 \mathrm{~h}$, Equiv. DIPEA: 9. Purification on a BetaBasic-18 column (A: $\mathrm{H}_{2} \mathrm{O} 0.1 \%$ TFA, B: MeCN $0.1 \%$ TFA with the following gradient program: $20 \%$ of B for $5 \mathrm{~min}, 20 \%$ to $60 \%$ of B in $45 \mathrm{~min}$, at a flow rate of $20 \mathrm{~mL} / \mathrm{min}$ ). The product 3BP-228 was obtained as a white powder (3 TFA salt, $21 \mathrm{mg}$, 40\%, purity: 93\%). RP-HPLC-MS: $\mathrm{t}_{\mathrm{r}}=3.83$ min, $m / z$ calculated for $\mathrm{C}_{57} \mathrm{H}_{82} \mathrm{~N}_{10} \mathrm{O}_{13}[\mathrm{M}+\mathrm{H}]^{+}$1115.6, found 1115.7. HRMS: $m / z$ calculated for $\mathrm{C}_{57} \mathrm{H}_{82} \mathrm{~N}_{10} \mathrm{O}_{13} \quad[\mathrm{M}+\mathrm{H}]^{+}$ 1115.61422, found $1115.61484 ; \mathrm{m} / \mathrm{z}$ calculated for $[\mathrm{M}+\mathrm{Na}]^{+}$ 1137.59605, found 1139.59447 .

2-((1-(4-((3-DOTAGA-aminopropyl)-(3dimethylaminopropyl)-carbamoyl)-2-isopropylphenyl)-5-(2,6dimethoxyphenyl)-1H-pyrazole-3-carbonyl)-amino)-adamantane-2-carboxylic acid (DOTAGA-16). Chelator: DOTAGA anhydride, Reaction time: 4 h, Equiv. DIPEA: 6. Purification on a BetaBasic- 18 column (A: $\mathrm{H}_{2} \mathrm{O} 0.1 \%$ TFA, B: MeCN 0.1\% TFA with the following gradient program: $30 \%$ of $\mathrm{B}$ for $5 \mathrm{~min}, 30 \%$ to $70 \%$ of $B$ in $50 \mathrm{~min}$, at a flow rate of $20 \mathrm{~mL} / \mathrm{min})$. The product DOTAGA-16 was obtained as a white powder (4 TFA salt, 21.59 mg, 37\%, purity: 97\%). RP-HPLC-MS: $\mathrm{t}_{\mathrm{r}}=3.82 \mathrm{~min}, \mathrm{~m} / \mathrm{z}$ calculated for $\mathrm{C}_{60} \mathrm{H}_{86} \mathrm{~N}_{10} \mathrm{O}_{15}[\mathrm{M}+\mathrm{H}]^{+}$1187.6, found 1187.6. HRMS: $m / z$ calculated for $\mathrm{C}_{60} \mathrm{H}_{86} \mathrm{~N}_{10} \mathrm{O}_{15} \quad[\mathrm{M}+\mathrm{H}]^{+}$1187.63535, found 1187.63587; $\mathrm{m} / \mathrm{z}$ calculated for $[\mathrm{M}+2 \mathrm{H}]^{2+} 594.32165$, found 594.32077.
2-((1-(4-((3-NOTA-aminopropyl)-(3-dimethylaminopropyl)carbamoyl)-2-isopropylphenyl)-5-(2,6-dimethoxyphenyl)-1Hpyrazole-3-carbonyl)-amino)-adamantane-2-carboxylic acid (NOTA-16). Chelator: NOTA-NHS, Reaction time: $3 \mathrm{~h}$, Equiv. DIPEA: 7.5. Purification on a BetaBasic- 18 column $\left(\mathrm{A}: \mathrm{H}_{2} \mathrm{O} 0.1 \%\right.$ TFA, B: MeCN $0.1 \%$ TFA with the following gradient program: $30 \%$ of B for $5 \mathrm{~min}, 30 \%$ to $60 \%$ of B in $50 \mathrm{~min}$, at a flow rate of $20 \mathrm{~mL} / \mathrm{min}$ ). The product NOTA-16 was isolated as a white powder (3 TFA salt, $14.39 \mathrm{mg}$, 30\%, purity: 98\%). RP-HPLC-MS: $t_{\mathrm{r}}=$ $3.85 \mathrm{~min}, \mathrm{~m} / \mathrm{z}$ calculated for $\mathrm{C}_{53} \mathrm{H}_{75} \mathrm{~N}_{9} \mathrm{O}_{11}[\mathrm{M}+\mathrm{H}]^{+}$1014.6, found 1014.6. HRMS: $m / z$ calculated for $\mathrm{C}_{53} \mathrm{H}_{75} \mathrm{~N}_{9} \mathrm{O}_{11} \quad[\mathrm{M}+\mathrm{H}]^{+}$ 1014.56654, found 1014.56629.

2-((1-(4-((3-NODAGA-aminopropyl)-(3dimethylaminopropyl)-carbamoyl)-2-isopropylphenyl)-5-(2,6dimethoxyphenyl)-1H-pyrazole-3-carbonyl)-amino)-adamantane-2-carboxylic acid (NODAGA-16). Chelator: NODAGANHS, Reaction time: $2 \mathrm{~h}$, Equiv. DIPEA : 8. Purification on a BetaBasic-18 column (A: $\mathrm{H}_{2} \mathrm{O} 0.1 \%$ TFA, B: MeCN $0.1 \%$ TFA with the following gradient program: $30 \%$ of $\mathrm{B}$ for $5 \mathrm{~min}, 30 \%$ to $70 \%$ of $\mathrm{B}$ in $50 \mathrm{~min}$, at a flow rate of $20 \mathrm{~mL} / \mathrm{min})$. The product NODAGA-16 was obtained as a white powder (4 TFA salt, 35.89 $\mathrm{mg}, 65 \%$, purity: $96 \%$ ). RP-HPLC-MS: $\mathrm{t}_{\mathrm{r}}=3.9 \mathrm{~min}, \mathrm{~m} / \mathrm{z}$ calculated for $\mathrm{C}_{56} \mathrm{H}_{79} \mathrm{~N}_{9} \mathrm{O}_{13}[\mathrm{M}+\mathrm{H}]^{+}$1086.6, found 1086.7. HRMS: $\mathrm{m} / z$ calculated for $\mathrm{C}_{56} \mathrm{H}_{79} \mathrm{~N}_{9} \mathrm{O}_{13}[\mathrm{M}+\mathrm{H}]^{+} 1086.58767$, found $1086.58672 ; \mathrm{m} / \mathrm{z}$ calculated for $[\mathrm{M}+2 \mathrm{H}]^{2+} 543.79781$, found 543.79634 .

2-((1-(4-((3-THP-aminopropyl)-(3-dimethylaminopropyl)carbamoyl)-2-isopropylphenyl)-5-(2,6-dimethoxyphenyl)-1Hpyrazole-3-carbonyl)-amino)-adamantane-2-carboxylic acid (THP-16). Chelator: THP-NCS, Reaction time: $4 \mathrm{~h}$, Equiv. DIPEA: 9. Purification on a BetaBasic-18 column (A: $\mathrm{H}_{2} \mathrm{O} 0.1 \%$ TFA, B: MeCN $0.1 \%$ TFA with the following gradient program: $30 \%$ of B for $5 \mathrm{~min}, 30 \%$ to $60 \%$ of B in $50 \mathrm{~min}$, at a flow rate of $20 \mathrm{~mL} / \mathrm{min}$ ). The product THP-16 was obtained as a white powder (7 TFA salt, $13.6 \mathrm{mg}, 46 \%$, purity: $97 \%$, the peak at $3.8 \mathrm{~min}$ corresponds to the expected compound and the peak at $4.1 \mathrm{~min}$ corresponds to a Fe-adduct formed during the analysis). RPHPLC-MS: $\operatorname{tr}_{\mathrm{r}}=3.84 \mathrm{~min}, \mathrm{~m} / \mathrm{z}$ calculated for $\mathrm{C}_{86} \mathrm{H}_{112} \mathrm{~N}_{16} \mathrm{O}_{16} \mathrm{~S}_{2}$ $[\mathrm{M}+2 \mathrm{H}]^{2+}$ 845.4, found 845.7. HRMS: $\mathrm{m} / \mathrm{z}$ calculated for $\mathrm{C}_{56} \mathrm{H}_{79} \mathrm{~N}_{9} \mathrm{O}_{13} \quad \mathrm{C}_{86} \mathrm{H}_{112} \mathrm{~N}_{16} \mathrm{O}_{16} \mathrm{~S}_{2} \quad[\mathrm{M}+2 \mathrm{H}]^{2+} \quad 845.38630$, found 845.40299; $\mathrm{m} / \mathrm{z}$ calculated for $[\mathrm{M}+3 \mathrm{H}]^{3+} 563.93739$, found 564.26978 .

Experimental Procedures and Characterization Data for bisDOTAGA-16. Lys $\left(\mathrm{DOTAGA}(t \mathrm{Bu})_{4}\right)_{2}$. To a solution of DOTAGA(tBu $)_{4}(40 \mathrm{mg}, 57 \mu \mathrm{mol}, 1.9$ equiv.) in anhydrous DMF $(1 \mathrm{~mL})$ with DIPEA $(21 \mu \mathrm{L}, 120 \mu \mathrm{mol}, 4$ equiv.) was added HATU (21.7 mg, $57 \mu \mathrm{mol}, 1.9$ equiv.). The yellow solution was stirred for $15 \mathrm{~min}$ at RT and DIPEA ( $21 \mu \mathrm{L}, 120 \mu \mathrm{mol}, 4$ equiv. $)$ and Llysine, monochlorhydrate ( $5.5 \mathrm{mg}, 30 \mathrm{mmol}, 1$ equiv.) were added. The reaction mixture was stirred for $4 \mathrm{~h}$ at RT. The reaction medium was concentrated under vacuum and purified on a BetaBasic- 18 column (A: $\mathrm{H}_{2} \mathrm{O} 0.1 \%$ TFA, B: MeCN 0.1\% TFA with the following gradient program: $20 \%$ of $\mathrm{B}$ for $5 \mathrm{~min}, 20 \%$ to $80 \%$ of $B$ in $70 \mathrm{~min}$, at a flow rate of $20 \mathrm{~mL} / \mathrm{min}$ ). The product was obtained as a white powder (4 TFA salt, $25.8 \mathrm{mg}, 44 \%$, purity: 90\%). RP-HPLC-MS: $\operatorname{tr}_{r}=3.88 \mathrm{~min}, \mathrm{~m} / \mathrm{z}$ calculated for $\mathrm{C}_{76} \mathrm{H}_{138} \mathrm{~N}_{10} \mathrm{O}_{20}[\mathrm{M}+1 \mathrm{H}]^{1+}$ 1512.01, found 1512.1; $[\mathrm{M}+2 \mathrm{H}]^{2+} 756.5$, found 756.5. HRMS: $\mathrm{m} / \mathrm{z}$ calculated for $\mathrm{C}_{76} \mathrm{H}_{138} \mathrm{~N}_{10} \mathrm{O}_{20}[\mathrm{M}+\mathrm{H}]^{+}$ 1512.01683, found 1512.01873; $\mathrm{m} / \mathrm{z}$ calculated for $[\mathrm{M}+2 \mathrm{H}]^{2+}$ 756.51239 , found 756.51434 . 
BisDOTAGA-16. To a solution of Lys(DOTAGA(tBu)4)2 (15.7 mg, $10.4 \mu \mathrm{mol}, 1$ equiv.) in anhydrous DMF $(0.5 \mathrm{~mL})$ was added DIPEA (5.4 $\mu \mathrm{L}, 31.2 \mu \mathrm{mol}, 3$ equiv.) and then HATU (3.95 mg, $10.4 \mu \mathrm{mol}, 1$ equiv.). The solution was stirred $15 \mathrm{~min}$ at RT and a solution of 16 ( $8.77 \mathrm{mg}, 10.4 \mu \mathrm{mol}, 1$ equiv.) in anhydrous DMF (0.5 mL) with DIPEA (7.3 $\mu \mathrm{L}, 41.6 \mu \mathrm{mol}, 4$ equiv.) was added. The reaction mixture was stirred $5 \mathrm{~h}$ at RT. The reaction medium was concentrated under vacuum and a solution of TFA:triisopropylsilane: $\mathrm{H}_{2} \mathrm{O}(95: 2.5: 2.5, v / v / v, 2 \mathrm{~mL})$ was added. The reaction was stirred for $3 \mathrm{~h}$ at $45^{\circ} \mathrm{C}$ and concentrated under a flow of nitrogen gas. The solution was purified on a BetaBasic18 column (A: $\mathrm{H}_{2} \mathrm{O} 0.1 \%$ TFA, B: MeCN $0.1 \%$ TFA with the following gradient program: $20 \%$ of $\mathrm{B}$ for $5 \mathrm{~min}, 20 \%$ to $60 \%$ of $\mathrm{B}$ in $60 \mathrm{~min}$, at a flow rate of $20 \mathrm{~mL} / \mathrm{min})$. The product bisDOTAGA16 was obtained as a white powder (4 TFA salt, $7.94 \mathrm{mg}, 34 \%$, purity: 97\%). RP-HPLC-MS: $\mathrm{t}_{\mathrm{r}}=3.73 \mathrm{~min}, \mathrm{~m} / \mathrm{z}$ calculated for $\mathrm{C}_{85} \mathrm{H}_{128} \mathrm{~N}_{16} \mathrm{O}_{25}[\mathrm{M}+2 \mathrm{H}]^{2+}$ 887.5, found 888.2; $[\mathrm{M}+3 \mathrm{H}]^{3+}$ 592.0, found 592.5. HRMS: $m / z$ calculated for $\mathrm{C}_{85} \mathrm{H}_{128} \mathrm{~N}_{16} \mathrm{O}_{25} \quad[\mathrm{M}+2 \mathrm{H}]^{2+}$ 887.46977, found 887.47499.

Experimental Procedures and Characterization Data for bisNODAGA-16. Lys $\left(\mathrm{NODAGA}(\mathrm{tBu})_{3}\right)_{2}$. To a solution of $\mathrm{NODAGA}(\mathrm{tBu}) 3(75 \mathrm{mg}, 0.138 \mathrm{mmol}, 2.5$ equiv.) in anhydrous DMF ( $1 \mathrm{~mL})$ with DIPEA ( $47.9 \mu \mathrm{L}, 0.275 \mathrm{mmol}, 5$ equiv.) was added TSTU ( $50 \mathrm{mg}, 0.165 \mathrm{mmol}, 3$ equiv.). The yellow solution was stirred for $30 \mathrm{~min}$ at RT and a suspension of L-lysine, monochlorhydrate (10 mg, $0.055 \mathrm{mmol}, 1$ equiv.) in DMF ( $1 \mathrm{~mL})$ and DIPEA ( $28.7 \mu \mathrm{L}, 0.165 \mathrm{mmol}, 3$ equiv) was added to the reaction mixture. The yellow suspension was stirred overnight at RT and heated for $4 \mathrm{~h}$ at $50{ }^{\circ} \mathrm{C}$. The reaction medium was concentrated under vacuum and purified on a BetaBasic-18 column $\left(\mathrm{A}: \mathrm{H}_{2} \mathrm{O}\right.$ $0.1 \%$ TFA, B: MeCN $0.1 \%$ TFA with the following gradient program: $25 \%$ of $B$ for $5 \mathrm{~min}, 25 \%$ to $75 \%$ of B in $50 \mathrm{~min}$, at a flow rate of $20 \mathrm{~mL} / \mathrm{min}$ ). The product was obtained as a white powder (3 TFA salt, $66.4 \mathrm{mg}$, 78\%, purity: 92\%). RP-HPLC-MS: $\mathrm{t}_{\mathrm{r}}=4.15$ min, $\mathrm{m} / \mathrm{z}$ calculated for $\mathrm{C}_{60} \mathrm{H}_{108} \mathrm{~N}_{8} \mathrm{O}_{16}[\mathrm{M}+\mathrm{H}]^{+}$1197.8, found 1197.8; $\mathrm{m} / \mathrm{z}$ calculated for $[\mathrm{M}+2 \mathrm{H}]^{2+} 599.4$, found 599.6. HRMS: $m / z$ calculated for $\mathrm{C}_{60} \mathrm{H}_{108} \mathrm{~N}_{8} \mathrm{O}_{16}[\mathrm{M}+\mathrm{H}]^{+}$1197.79627, found 1197.79853; $\mathrm{m} / \mathrm{z}$ calculated for $[\mathrm{M}+2 \mathrm{H}]^{2+}$ 599.40211, found 599.40336.

BisNODAGA-16. To a solution of Lys(NODAGA $\left.(t \mathrm{Bu})_{3}\right)_{2}(15$ mg, $12.5 \mu \mathrm{mol}, 1$ equiv.) in anhydrous $\operatorname{DMF}(0.75 \mathrm{~mL})$ with DIPEA $(6.5 \mu \mathrm{L}, 37.5 \mu \mathrm{mol}, 3$ equiv.) was added HATU $(4.75 \mathrm{mg}$, $12.5 \mu \mathrm{mol}, 1$ equiv.). The solution was stirred for $15 \mathrm{~min}$ at RT and a solution of 16 (10.5 mg, $12.5 \mu \mathrm{mol}, 1$ equiv.) in anhydrous DMF $(0.75 \mathrm{~mL})$ with DIPEA $(8.7 \mu \mathrm{L}, 50.0 \mu \mathrm{mol}, 4$ equiv.) was added. The reaction mixture was left stirring for $3 \mathrm{~h}$ at RT. The reaction medium was concentrated under vacuum and a solution of TFA:triisopropylsilane: $\mathrm{H}_{2} \mathrm{O}(95: 2.5: 2.5, v / v / v, 2 \mathrm{~mL})$ was added. The reaction was stirred for $6 \mathrm{~h}$ at RT and concentrated under a flow of nitrogen gas. The residue was purified on a BetaBasic-18 column (A: $\mathrm{H}_{2} \mathrm{O} 0.1 \%$ TFA, B: MeCN 0.1\% TFA with the following gradient program: $20 \%$ of $\mathrm{B}$ for $5 \mathrm{~min}, 20 \%$ to $60 \%$ of $\mathrm{B}$ in $40 \mathrm{~min}$, at a flow rate of $20 \mathrm{~mL} / \mathrm{min}$ ). The product bisNODAGA-16 was obtained as a white powder (4 TFA salt, $12.0 \mathrm{mg}$, 47\%, purity: 98\%). RP-HPLC-MS: $\mathrm{t}_{\mathrm{r}}=3.90 \mathrm{~min}, \mathrm{~m} / \mathrm{z}$ calculated for $\mathrm{C}_{77} \mathrm{H}_{114} \mathrm{~N}_{14} \mathrm{O}_{21}[\mathrm{M}+2 \mathrm{H}]^{2+}$ 786.4, found 786.4. HRMS: $m / z$ calculated for $\mathrm{C}_{77} \mathrm{H}_{114} \mathrm{~N}_{14} \mathrm{O}_{21}[\mathrm{M}+\mathrm{H}]^{+}$1571.83624, found 1571.83830; $\mathrm{m} / \mathrm{z}$ calculated for $[\mathrm{M}+2 \mathrm{H}]^{2+} 786.42209$, found 786.42406
General procedure for the metalation with nat $\mathrm{Ga}$. The compounds were dissolved in acetate buffer $(0.5 \mathrm{~mL}, 0.1 \mathrm{M}, \mathrm{pH} 3.48)$. A solution of $\mathrm{Ga}\left(\mathrm{NO}_{3}\right)_{3}$ (1.5 equiv. for 3BP-227, 3BP-228, DOTAGA-16, NOTA-16, NODAGA-16 and THP-16 and 4 equiv. for bisDOTAGA-16 and bisNODAGA-16) in acetate buffer (0.5 $\mathrm{mL}$ ) was then added. The reaction mixture was stirred for $5 \mathrm{~h}$ at $40{ }^{\circ} \mathrm{C}$. The excess of free gallium was removed by semi-preparative RP-HPLC.

${ }^{n a t} \mathrm{Ga}-3 \mathrm{BP}-227$. Purification on a BetaBasic-18 column $\left(\mathrm{A}: \mathrm{H}_{2} \mathrm{O}\right.$ $0.1 \%$ TFA, B: MeCN $0.1 \%$ TFA with the following gradient program: $30 \%$ of B for $5 \mathrm{~min}, 30 \%$ to $60 \%$ of B in $50 \mathrm{~min}$, at a flow rate of $20 \mathrm{~mL} / \mathrm{min}$ ). The product was obtained as a white powder (5 TFA salt, $5.8 \mathrm{mg}$, 49\%, purity: 97\%). RP-HPLC-MS: $\mathrm{t}_{\mathrm{r}}=3.85$ min. MALDI-TOF: $m / z$ calculated for $\mathrm{C}_{58} \mathrm{H}_{81} \mathrm{GaN}_{10} \mathrm{O}_{13}[\mathrm{M}+\mathrm{H}]^{+}$ 1195.532, found 1195.703.

${ }^{n a t} \mathrm{Ga}-3 B P-228$. Purification on a BetaBasic-18 column $\left(\mathrm{A}: \mathrm{H}_{2} \mathrm{O}\right.$ $0.1 \%$ TFA, B: MeCN $0.1 \%$ TFA with the following gradient program: $30 \%$ of B for $5 \mathrm{~min}, 30 \%$ to $60 \%$ of B in $50 \mathrm{~min}$, at a flow rate of $20 \mathrm{~mL} / \mathrm{min})$. The product was obtained as a white powder (3 TFA salt, $8.7 \mathrm{mg}, 70 \%$, purity: 97\%). RP-HPLC-MS: $\mathrm{t}_{\mathrm{r}}=3.77$ min. MALDI-TOF: $m / z$ calculated for $\mathrm{C}_{57} \mathrm{H}_{79} \mathrm{GaN}_{10} \mathrm{O}_{13}[\mathrm{M}+\mathrm{H}]^{+}$ 1181.516, found 1181.844.

${ }^{n a t}$ Ga-DOTAGA-16. Purification on a BetaBasic-18 column (A: $\mathrm{H}_{2} \mathrm{O} 0.1 \%$ TFA, B: MeCN $0.1 \%$ TFA with the following gradient program: $30 \%$ of B for $5 \mathrm{~min}, 30 \%$ to $60 \%$ of B in $50 \mathrm{~min}$, at a flow rate of $20 \mathrm{~mL} / \mathrm{min}$ ). The product was obtained as a white powder (5 TFA salt, $7.1 \mathrm{mg}, 51 \%$, purity: 92\%). RP-HPLC-MS: $\mathrm{t}_{\mathrm{r}}=3.87$ min. MALDI-TOF: $\mathrm{m} / \mathrm{z}$ calculated for $\mathrm{C}_{60} \mathrm{H}_{82} \mathrm{GaN}_{10} \mathrm{O}_{15}[\mathrm{M}+\mathrm{H}]^{+}$ 1252.530, found 1253.844 .

${ }^{n a t} \mathrm{Ga}-\mathrm{NOTA}$-16. Purification on a BetaBasic-18 column (A: $\mathrm{H}_{2} \mathrm{O} 0.1 \%$ TFA, B: MeCN $0.1 \%$ TFA with the following gradient program: $25 \%$ of B for $5 \mathrm{~min}, 25 \%$ to $50 \%$ of B in $50 \mathrm{~min}$, at a flow rate of $20 \mathrm{~mL} / \mathrm{min}$ ). The product was obtained as a white powder (3 TFA salt, $10.6 \mathrm{mg}$, 84\%, purity: 99\%). RP-HPLC-MS: $\mathrm{tr}_{\mathrm{r}}=3.66$ min. MALDI-TOF: $m / z$ calculated for $\mathrm{C}_{53} \mathrm{H}_{73} \mathrm{GaN}_{9} \mathrm{O}_{11}{ }^{+}[\mathrm{M}+\mathrm{H}]^{+}$ 1081.476, found 1080.467 .

${ }^{n a t} G a-N O D A G A-16$. Purification on a BetaBasic-18 column (A: $\mathrm{H}_{2} \mathrm{O} 0.1 \%$ TFA, B: MeCN $0.1 \%$ TFA with the following gradient program: $30 \%$ of B for $5 \mathrm{~min}, 30 \%$ to $60 \%$ of B in $50 \mathrm{~min}$, at a flow rate of $20 \mathrm{~mL} / \mathrm{min}$ ). The compound was obtained as a white powder (3 TFA salt, $4.35 \mathrm{mg}$, 35\%, purity $>99 \%$ ). RP-HPLC-MS: $\mathrm{t}_{\mathrm{r}}=$ $3.9 \mathrm{~min}$. MALDI-TOF: $\mathrm{m} / \mathrm{z}$ calculated for $\mathrm{C}_{56} \mathrm{H}_{76} \mathrm{GaN}_{9} \mathrm{O}_{13}[\mathrm{M}+\mathrm{H}]^{+}$ 1152.490, found 1152.454 .

${ }^{n a t} \mathbf{G a}$-THP-16. Purification on a BetaBasic-18 column $\left(\mathrm{A}: \mathrm{H}_{2} \mathrm{O}\right.$ $0.1 \%$ TFA, B: MeCN $0.1 \%$ TFA with the following gradient program: $35 \%$ of B for $5 \mathrm{~min}, 35 \%$ to $60 \%$ of B in $40 \mathrm{~min}$, at a flow rate of $20 \mathrm{~mL} / \mathrm{min}$ ). The product was obtained as a white powder (9 TFA salt, $6 \mathrm{mg}$, 53\%, purity: 77+20\%). RP-HPLC-MS: $\mathrm{tr}_{\mathrm{r}}=4.2$ min. MALDI-TOF: $m / z$ calculated for $\mathrm{C}_{86} \mathrm{H}_{109} \mathrm{GaN}_{16} \mathrm{O}_{16} \mathrm{~S}_{2}[\mathrm{M}+\mathrm{H}]^{+}$ 1755.698, found 1757.551.

${ }^{n a t}$ Ga-bisDOTAGA-16. Purification on a BetaBasic-18 column (A: $\mathrm{H}_{2} \mathrm{O} 0.1 \%$ TFA, B: MeCN $0.1 \%$ TFA with the following gradient program: $20 \%$ of $B$ for $5 \mathrm{~min}, 20 \%$ to $60 \%$ of $B$ in $40 \mathrm{~min}$, at a flow rate of $20 \mathrm{~mL} / \mathrm{min}$ ). The product was obtained as a white powder (3 TFA salt, $5.44 \mathrm{mg}$, 78\%, purity: 97.4\%). RP-HPLC-MS: $\mathrm{t}_{\mathrm{r}}=3.73 \mathrm{~min}$. MALDI-TOF: $\mathrm{m} / \mathrm{z}$ calculated for $\mathrm{C}_{85} \mathrm{H}_{122} \mathrm{Ga}_{2} \mathrm{~N}_{16} \mathrm{O}_{25}$ $[\mathrm{M}+\mathrm{H}]^{+}$1907.735, found 1908.386. 
${ }^{n a t}$ Ga-bisNODAGA-16. Purification on a BetaBasic-18 column (A: $\mathrm{H}_{2} \mathrm{O} 0.1 \%$ TFA, B: MeCN $0.1 \%$ TFA with the following gradient program: $20 \%$ of $\mathrm{B}$ for $5 \mathrm{~min}, 20 \%$ to $60 \%$ of $\mathrm{B}$ in $40 \mathrm{~min}$, at a flow rate of $20 \mathrm{~mL} / \mathrm{min}$ ). The product was obtained as a white powder (3 TFA salt, $5.33 \mathrm{mg}$, 77\%, purity: 96\%). RP-HPLC-MS: $\mathrm{t}_{\mathrm{r}}$ $=3.72 \mathrm{~min}$. MALDI-TOF: $\mathrm{m} / \mathrm{z}$ calculated for $\mathrm{C}_{77} \mathrm{H}_{108} \mathrm{Ga}_{2} \mathrm{~N}_{14} \mathrm{O}_{21}$ $[\mathrm{M}+\mathrm{H}]^{+}$1706.643, found 1706.394 .

In vitro stability. $15 \mu \mathrm{L}$ of a $5 \mathrm{mM}$ stock solution of compound in DMSO $50 \%(v / v)$ were stirred in a thermomixer (900 rpm, $37^{\circ} \mathrm{C}$, dark) with $135 \mu \mathrm{L}$ of mouse serum (Sigma Aldrich, M5905, batch SLBT4412). The final concentration in peptide was $0.5 \mathrm{mM}$. After $0 \mathrm{~min}, 30 \mathrm{~min}, 1 \mathrm{~h}, 2 \mathrm{~h}, 4 \mathrm{~h}$ and $24 \mathrm{~h}$, a sample $(15 \mu \mathrm{L})$ of solution was collected and diluted with $60 \mu \mathrm{L}$ of ethanol $99 \%$. $15 \mu \mathrm{L}$ of a $1 \mathrm{mM}$ stock solution of Fmoc$\operatorname{Trp}(\mathrm{tBu})-\mathrm{OH}$ was added to the suspension for internal calibration. Samples were vortexed and centrifuged (10000 rpm, 10 minutes) to remove precipitated proteins. The supernatant was analyzed by RP-HPLC-MS at a wavelength of $260 \mathrm{~nm}$.

In vitro binding affinity. The affinity of each compound Ga3BP-227, Ga-3BP-228, Ga-DOTAGA-16, Ga-NOTA-16, GaNODAGA-16, Ga-THP-16, Ga-bisDOTAGA-16, GabisNODAGA-16 for $\mathrm{NTS}_{1}$ was determined on a competitive binding assay on human recombinant $\mathrm{CHO}$ cells overexpressing $\mathrm{NTS}_{1}$, using [125I]I-Tyr ${ }^{3}$-neurotensin $\left(0.05 \mathrm{nM} ; \mathrm{K}_{\mathrm{d}}=0.22 \mathrm{nM}\right)$ as the radioligand (Eurofins, France). Non-specific binding was measured in presence of an excess of neurotensin $(1 \mu \mathrm{M})$. Experiments were performed in duplicate. Data were fitted by nonlinear regression, using GraphPadPrism, 6.0 software. The minimum was set to 0 . $\mathrm{IC}_{50}$ values were converted into inhibition constants $\left(\mathrm{K}_{\mathrm{i}}\right)$ using the Cheng-Prusoff equation.

Radiolabeling of compounds with ${ }^{68} \mathrm{Ga}$. Compounds were radiolabeled using a Modular-Lab PharmTracer (Eckert \& Ziegler). Fractional elution of the ${ }^{68} \mathrm{Ge} /{ }^{68} \mathrm{Ga}$ generator gave a solution $(1.5 \mathrm{~mL}, 90 \mathrm{MBq})$ which was added to a solution of $2.99 \mathrm{nmol}$ of each compound in $\mathrm{EtOH}(150 \mu \mathrm{L})$ and ammonium acetate buffer (1 M, pH 6.88) to adjust the $\mathrm{pH}$ to 3.5. The reaction mixture was incubated at $37{ }^{\circ} \mathrm{C}$ for $5 \mathrm{~min}$ for the NOTA-, NODAGA- and THP-based compounds, and at $95{ }^{\circ} \mathrm{C}$ for $10 \mathrm{~min}$ for the DOTAand DOTAGA-based compounds. The products were purified on a $\mathrm{C}_{18}$ Sep-Pack cartridge (Waters, Milford, MA), eluted using $1000 \mu \mathrm{L}$ of $80 \%$ ethanol in the second reactor, and subsequently evaporated at $70{ }^{\circ} \mathrm{C}$ for $10 \mathrm{~min}$ under an air flow. The final products were diluted with $0.9 \%$ sodium chloride $(\mathrm{NaCl})$. HPLC quality control was performed using a HPLC system LC-2000 analytical series (Jasco) equipped with a Flowcount radioactivity detector (Bioscan). Separation was achieved using an RP $\mathrm{C}_{18}$ Kinetex $^{\mathrm{TM}}$ column (Phenomenex) $(2.6 \mu \mathrm{m}, 100 \AA$, $50 \times 2.1 \mathrm{~mm})$ with ultrapure water and HPLC-grade $\mathrm{MeCN}$ (A: $\mathrm{H}_{2} \mathrm{O} 0.1 \%$ TFA and B: MeCN $0.1 \%$ TFA). Analyses were performed with the following gradient program: $5 \%$ to $95 \%$ of $\mathrm{B}$ in $5 \mathrm{~min}, 95 \% \mathrm{~B}$ for $1.5 \mathrm{~min}$, at a flow rate of $0.5 \mathrm{~mL} / \mathrm{min}$. The quantity of colloids was evaluated using a system of two instant thin layer chromatographies (iTLC) eluted with citrate sodium and $\mathrm{NH}_{4} \mathrm{Ac} / \mathrm{MeOH}$ as mobile phases.

Small animal PET imaging and biodistribution studies on the HT29 tumor model. All animal studies were conducted at and approved by the Centre George François Leclerc (CGFL) in accordance with the relevant guidelines and legislation on the use of laboratory animals (directive 2010/63/EU) and were approved by accredited Ethical Committee (C2ea Grand Campus ${ }^{\circ}{ }^{105}$ ) and French Ministry of Higher Education and Research (\#15316). HT-29 tumor bearing mice ( 8 weeks old, 10x106 cells per mouse injected subcutaneously in the right flack) were intravenously injected in the tail vein with 3 to $8 \mathrm{MBq}$ of each radiotracer based on a consistent number of picomoles being injected (500 pmol). Static PET and MRI images were simultaneously recorded 90 $\min$ p.i. for $30 \mathrm{~min}$. The mice were awakened between the administration of the tracer and imaging times. Images were recorded in a dual-ring SiPM microPET fully integrated in a 7T preclinical MRI (MR Solutions, Guilford, UK). The animals were kept under anesthesia using $2 \%$ isofluorane in oxygen and positioned in a dedicated heating cradle during imaging. Respiratory gating was performed with abdominal pressure sensor and dedicated software (PC Sam, SAII, Stony Brook, US). List-mode data were collected in the PET system during $30 \mathrm{~min}$. Coronal T1 weighted fast spin echo MR images were acquired with respiratory gating and the following parameters: 16 slices with a time of repetition (TR) of $1000 \mathrm{~ms}$, time of echo (TE) of $11 \mathrm{~ms} .3$ signal averages, $1 \mathrm{~mm}$ slice thickness, field of view (FOV) of 70 $\mathrm{mm}$ and 256x256 pixels matrix. Images were reconstructed with the $3 \mathrm{D}$ ordered subset expectation maximization (OSEM) algorithm implemented in the system using 2 iterations, 32 subsets and an isotropic voxel size of $0.28 \mathrm{~mm}$. An energy window of 250-750 keV and a coincidence time window of $8 \mathrm{~ns}$ were applied to the list-mode data. The algorithm takes into account normalization, random and decay corrections. No attenuation correction was applied. Two hours post-injection, mice were sacrificed and the main organs and tissues were dissected, weighed, and $\gamma$ counted (1480 Wizard 3, PerkinElmer). Blocking experiments were performed by co-injecting an excess (100 equivalents) of SR142948A. Tumor or tissue uptake are expressed as mean \pm SD percentage injected dose per gram (\%ID/g), corrected for radionuclide decay. Statistical significance between different groups was analyzed by the one-way analysis of variance, with $\left[{ }^{68} \mathrm{Ga}\right] \mathrm{Ga}-3 \mathrm{BP}-228$ as control group, followed by Bonferroni correction. Statistical significance in blocking experiments was assessed by the unpaired two-tailed Student's t-test.

Binding studies on HT29 cells. Experiments were performed with $1 \times 10^{6}$ cells per well in 24 -well plates. Cells were washed with ice cold PBS twice before their incubation with 8 different concentrations of $\left[{ }^{68} \mathrm{Ga}\right.$ ]Ga-bisNODAGA-16 (from $78 \mathrm{pM}$ to 10 $\mathrm{nM}$ ) in $1 \mathrm{~mL}$ of incubation medium. The compound was incubated alone or in the presence of an excess $(1 \mu \mathrm{M})$ of the ligands SR142948A, neurotensin or levocabastin, for $60 \mathrm{~min}$ at $4{ }^{\circ} \mathrm{C}$. The medium was then withdrawn, cells were washed twice with ice cold PBS and solubilized in $1 \mathrm{M} \mathrm{NaOH}$. The amount of radioactivity was measured using a $\gamma$-counter (Wallac Wizard 1470, Perkin Elmer, USA). Experiments were performed in triplicate. Data were fitted, using GraphPad Prism 6.0 software, by applying the one site binding model.

Calcium mobilization assay. Antagonist activities were determined on a fluorescent assay measuring $\left[\mathrm{Ca}^{2+}\right]$ mobilization in $\mathrm{CHO}$ cells overexpressing human recombinant $\mathrm{NTS}_{1}$, upon stimulation by neurotensin $(0.3 \mathrm{nM})$, in the presence of increasing concentrations of natGa-bisNODAGA-16 (Eurofins, France). ${ }^{19}$ SR142948A was used as an internal control $\left(\mathrm{IC}_{50}=23 \mathrm{nM}\right.$; $\mathrm{K}_{\mathrm{B}}=$ $2.1 \mathrm{nM}$ ). Results are expressed as a percent inhibition of control agonist response. IC 50 values were determined by non-linear regression of normalized response curves, using GraphPad Prism, 6.0 software. 
Small animal PET-CT imaging and biodistribution studies on the AsPC-1 tumor model. Animal experiments were conducted in compliance with the French laws, in application of the directive 2010/63/ EU and were approved by the "Charles Darwin" Institutional Animal Care and Use Committee of Sorbonne University \#13184. AsPC1 tumor bearing mice (10 weeks old, $5 \times 10^{6}$ cells per mouse injected subcutaneously on the right shoulder in a 1:1 mixture of PBS and matrigel (BD Biosciences)) were intravenously (retro-orbitary sinus) injected with 4 to $6 \mathrm{MBq}$ of radiotracer $(619 \pm 36 \mathrm{pmol})$. Whole body static PET/computed tomography (CT) scans were performed under general anesthesia in a NanoScan PET/CT (Mediso Medical Imaging Systems Ltd., Budapest, Hungary) $50 \mathrm{~min}$ or $90 \mathrm{~min}$ after injection during 20 min scans using multiple bed ( 3 mice simultaneously). Anesthesia was induced and maintained during imaging by the administration of a mixture of isoflurane (1.5-2.5\%) and oxygen. CT acquisitions were performed before PET acquisitions using the same bed position. PET and CT files were fused and converted to standardized uptake value (SUV) images using Nucline 2.03 Software (Mediso Medical Imaging Systems, Hungary). Images are analysed and presented as coronal or axial slices. Ex vivo biodistribution was measured for $\mathrm{n}=4$ mice at $120 \mathrm{~min}$ post injection (p.i.). Organs were collected, weighed, and $\gamma$-counted (Packard Instrument). Tumor or tissue uptakes are expressed as mean \pm SD percentage injected dose per gram $(\% \mathrm{ID} / \mathrm{g})$, corrected for radionuclide decay.

\section{ASSOCIATED CONTENT}

\section{Supporting Information}

The Supporting Information is available free of charge on the ACS Publications website.

Materials and general procedures, synthesis schemes and analytical data for all compounds, in vitro stability data, in vitro binding affinity data, radiolabeling data, PET-MRI images, PET-CT images, tables of ex vivo biodistribution data determined by $\gamma$-counting, blocking experiment data (PDF)

Animated 3D PET images (MP4)

SMILES formula of each compound and associated biochemical data (CSV)

\section{AUTHOR INFORMATION}

\section{Corresponding Author}

*E-mail: victor.goncalves@u-bourgogne.fr.

\section{Author Contributions}

All authors have given approval to the final version of the manuscript.

\section{ACKNOWLEDGMENT}

The authors thank the Plateforme d'Analyse Chimique et de Synthèse Moléculaire de l'Université de Bourgogne (http://www.wpcm.fr) for access to analytical instrumentation (specially Dr. M. Laly for the ionic chromatography and Dr. Q. Bonnin for the HRMS analysis). This work was partly funded by the French National Research Agency (ANR) under the French Investissements d'Avenir programs Equipex (IMAPPI, ANR-10-EQPX-05-01), AAP Générique 2017
(ZINELABEL, ANR-17-CE18-0016), and by France Life Imaging (ANR-11-INBS-0006). This work was also supported by the CNRS and the Universite de Bourgogne. This work is part of the project Pharmaco-imagerie et agents théranostiques funded by the Conseil Régional de Bourgogne Franche-Comté through the Plan d'Action Régional pour l'Innovation (PARI) and by the European Union through the PO FEDER-FSE 2014/2020 Bourgogne program.

\section{ABBREVIATIONS}

$\mathrm{CHO}$, Chinese hamster ovary; DOTA, 1,4,7,10-tetraazacyclododecane-1,4,7,10-tetraacetic acid; DOTAGA, 1,4,7,10tetraazacyclododecane-1-glutaric acid-4,7,10-triacetic acid; NCS, N-chlorosuccinimide; NHS, N-hydroxysuccinimide; NOTA, 1,4,7-triazacyclononane-1,4,7-triacetic acid; NODAGA, 1,4,7-triazacyclononane-1-glutaric acid-4,7-diacetic acid; NTS1, neurotensin receptor 1; PBS, phosphate buffer saline; PET, positron emission tomography; RPHPLC, reverse phase high-performance liquid chromatography; $\mathrm{RT}$, room temperature; $\mathrm{SD}$, standard deviation

\section{REFERENCES}

(1) Vaquero, J. J.; Kinahan, P. Positron Emission Tomography: Current Challenges and Opportunities for Technological Advances in Clinical and Preclinical Imaging Systems. Annu. Rev. Biomed. Eng. 2015, $17 \quad$ (1), 385-414. https://doi.org/10.1146/annurev-bioeng-071114-040723.

(2) $\mathrm{Wu}, \mathrm{Z}$;; Martinez-Fong, D.; Trédaniel, J.; Forgez, P. Neurotensin and Its High Affinity Receptor 1 as a Potential Pharmacological Target in Cancer Therapy. Front. Endocrinol. 2013, 3, 184. https://doi.org/10.3389/fendo.2012.00184.

(3) Carraway, R. E.; Plona, A. M. Involvement of Neurotensin in Cancer Growth: Evidence, Mechanisms and Development of Diagnostic Tools. Peptides 2006, 27 (10), 2445-2460. https://doi.org/10.1016/j.peptides.2006.04.030.

(4) Reubi, J.; Waser, B.; Friess, H.; Buchler, M.; Laissue, J. Neurotensin Receptors: A New Marker for Human Ductal Pancreatic Adenocarcinoma. Gut 1998, 42 (4), 546-550.

(5) Seethalakshmi, L.; Mitra, S. P.; Dobner, P. R.; Menon, M.; Carraway, R. E. Neurotensin Receptor Expression in Prostate Cancer Cell Line and Growth Effect of NT at Physiological Concentrations. The Prostate 1997, 31 (3), 183-192. https://doi.org/10.1002/(SICI)10970045(19970515)31:3<183::AID-PROS7>3.0.CO;2-M.

(6) Reubi, J. C.; Waser, B.; Schaer, J. C.; Laissue, J. A. Neurotensin Receptors in Human Neoplasms: High Incidence in Ewing's Sarcomas. Int. J. Cancer 1999, 82 (2), 213-218. https://doi.org/10.1002/(sici)1097-0215(19990719)82:2<213::aidijc11>3.0.co;2-8.

(7) Maoret, J. J.; Pospaï, D.; Rouyer-Fessard, C.; Couvineau, A.; Laboisse, C.; Voisin, T.; Laburthe, M. Neurotensin Receptor and Its MRNA Are Expressed in Many Human Colon Cancer Cell Lines but Not in Normal Colonic Epithelium: Binding Studies and RT-PCR Experiments. Biochem. Biophys. Res. Commun. 1994, $203 \quad$ (1), 465-471. https://doi.org/10.1006/bbrc.1994.2205.

(8) Souazé, F.; Dupouy, S.; Viardot-Foucault, V.; Bruyneel, E.; Attoub, S.; Gespach, C.; Gompel, A.; Forgez, P. Expression of 
Neurotensin and NT1 Receptor in Human Breast Cancer: A Potential Role in Tumor Progression. Cancer Res. 2006, 66 (12), 6243-6249. https://doi.org/10.1158/0008-5472.CAN-06-0450.

(9) Reeve, J. G.; Goedert, M.; Emson, P. C.; Bleehen, N. M. Neurotensin in Human Small Cell Lung Carcinoma. Recent Results Cancer Res. 1985, 99, 175-176. https://doi.org/10.1007/978-3642-82533-0_18.

(10) Carraway, R.; Leeman, S. E. The Isolation of a New Hypotensive Peptide, Neurotensin, from Bovine Hypothalami. J. Biol. Chem. 1973, 248 (19), 6854-6861.

(11) Prignon, A.; Provost, C.; Alshoukr, F.; Wendum, D.; Couvelard, A.; Barbet, J.; Forgez, P.; Talbot, J.-N.; Gruaz-Guyon, A. Preclinical Evaluation of 68Ga-DOTA-NT-20.3: A Promising PET Imaging Probe To Discriminate Human Pancreatic Ductal Adenocarcinoma from Pancreatitis. Mol. Pharmaceutics 2019, 16 (6), 2776-2784. https://doi.org/10.1021/acs.molpharmaceut.9b00283.

(12) Maschauer, S.; Prante, O. Radiopharmaceuticals for Imaging and Endoradiotherapy of Neurotensin Receptor-Positive Tumors. J. Labelled Compd. Radiopharm. 2018, 61 (3), 309-325. https://doi.org/10.1002/jlcr.3581.

(13) Yin, X.; Wang, M.; Wang, H.; Deng, H.; He, T.; Tan, Y.; Zhu, Z.; Wu, Z.; Hu, S.; Li, Z. Evaluation of Neurotensin Receptor 1 as a Potential Imaging Target in Pancreatic Ductal Adenocarcinoma. Amino Acids 2017, 49 (8), 1325-1335. https://doi.org/10.1007/s00726-017-2430-5.

(14) Renard, E.; Dancer, P.-A.; Portal, C.; Denat, F.; Prignon, A.; Goncalves, V. Design of Bimodal Ligands of Neurotensin Receptor 1 for Positron Emission Tomography Imaging and Fluorescence-Guided Surgery of Pancreatic Cancer. J. Med. Chem. 2020, 63 (5), 2426-2433. https://doi.org/10.1021/acs.jmedchem.9b01407.

(15) Kitabgi, P.; De Nadai, F.; Rovère, C.; Bidard, J. N. Biosynthesis, Maturation, Release, and Degradation of Neurotensin and Neuromedin N. Ann. N. Y. Acad. Sci. 1992, 668, 30-42. https://doi.org/10.1111/j.1749-6632.1992.tb27337.x.

(16) Gabriel, M.; Decristoforo, C.; Wöll, E.; Eisterer, W.; Nock, B.; Maina, T.; Moncayo, R.; Virgolini, I. [99mTc]Demotensin VI: Biodistribution and Initial Clinical Results in Tumor Patients of a Pilot/Phase I Study. Cancer Biother. Radiopharm. 2011, 26 (5), 557-563. https://doi.org/10.1089/cbr.2010.0952.

(17) Gully, D.; Canton, M.; Boigegrain, R.; Jeanjean, F.; Molimard, J. C.; Poncelet, M.; Gueudet, C.; Heaulme, M.; Leyris, R.; Brouard, A. Biochemical and Pharmacological Profile of a Potent and Selective Nonpeptide Antagonist of the Neurotensin Receptor. PNAS 1993, 90 (1), 65-69. https://doi.org/10.1073/pnas.90.1.65.

(18) Myers, R. M.; Shearman, J. W.; Kitching, M. O.; RamosMontoya, A.; Neal, D. E.; Ley, S. V. Cancer, Chemistry, and the Cell: Molecules That Interact with the Neurotensin Receptors. ACS Chem. Biol. 2009, 4 (7), 503-525. https://doi.org/10.1021/cb900038e.

(19) Gully, D.; Labeeuw, B.; Boigegrain, R.; Oury-Donat, F.; Bachy, A.; Poncelet, M.; Pecceu, F.; Maffrand, J. P. Biochemical and Pharmacological Activities of SR 142948A, a New Potent Neurotensin Receptor Antagonist. J. Pharmacol. Exp. Ther. 1997, 280, 802-812.

(20) Betancur, C.; Canton, M.; Burgos, A.; Labeeuw, B.; Gully, D.; Rostene, W.; Pelaprat, D. Characterization of Binding
Sites of a New Neurotensin Receptor Antagonist, [3H]SR 142948A, in the Rat Brain. Eur. J. Pharm. 1998, 343, 67-77.

(21) Lang, C.; Maschauer, S.; Hübner, H.; Gmeiner, P.; Prante, O. Synthesis and Evaluation of a ${ }^{18}$ F-Labeled Diarylpyrazole Glycoconjugate for the Imaging of NTS1-Positive Tumors. J. Med. Chem. 2013, 56 (22), 9361-9365. https://doi.org/10.1021/jm401491e.

(22) Schulz, J.; Rohracker, M.; Stiebler, M.; Goldschmidt, J.; Stöber, F.; Noriega, M.; Pethe, A.; Lukas, M.; Osterkamp, F.; Reineke, U.; Höhne, A.; Smerling, C.; Amthauer, H. Proof of Therapeutic Efficacy of a ${ }^{177}$ Lu-Labeled Neurotensin Receptor 1 Antagonist in a Colon Carcinoma Xenograft Model. J. Nucl. Med. 2017, 58 (6), 936-941. https://doi.org/10.2967/jnumed.116.185140.

(23) Ginj, M.; Zhang, H.; Waser, B.; Cescato, R.; Wild, D.; Wang, X.; Erchegyi, J.; Rivier, J.; Mäcke, H. R.; Reubi, J. C. Radiolabeled Somatostatin Receptor Antagonists Are Preferable to Agonists for in Vivo Peptide Receptor Targeting of Tumors. Proc. Natl. Acad. Sci. U.S.A. 2006, 103 (44), 16436-16441. https://doi.org/10.1073/pnas.0607761103.

(24) Fani, M.; Maecke, H. R. Radiopharmaceutical Development of Radiolabelled Peptides. Eur. J. Nucl. Med. Mol. Imaging 2012, 39 (Suppl 1), S11-30. https://doi.org/10.1007/s00259-0112001-z.

(25) Dash, A.; Chakraborty, S.; Pillai, M. R. A.; Knapp, F. F. R. Peptide Receptor Radionuclide Therapy: An Overview. Cancer Biother. Radiopharm. 2015, 30 (2), 47-71. https://doi.org/10.1089/cbr.2014.1741.

(26) Schulz, J.; Rohracker, M.; Stiebler, M.; Goldschmidt, J.; Grosser, O. S.; Osterkamp, F.; Pethe, A.; Reineke, U.; Smerling, C.; Amthauer, H. Comparative Evaluation of the Biodistribution Profiles of a Series of Nonpeptidic Neurotensin Receptor-1 Antagonists Reveals a Promising Candidate for Theranostic Applications. J. Nucl. Med. 2016, 57 (7), 1120-1123. https://doi.org/10.2967/jnumed.115.170530.

(27) Study to Evaluate the Safety and Activity (Including Distribution) of 177Lu-3BP-227 in Subjects With Solid Tumours Expressing Neurotensin Receptor Type 1. - Tabular View - ClinicalTrials.gov https://clinicaltrials.gov/ct2/show/record/NCT03525392 (accessed Apr 23, 2020).

(28) Baum, R. P.; Singh, A.; Schuchardt, C.; Kulkarni, H. R.; Klette, I.; Wiessalla, S.; Osterkamp, F.; Reineke, U.; Smerling, C. 177 Lu-3BP-227 for Neurotensin Receptor 1-Targeted Therapy of Metastatic Pancreatic Adenocarcinoma: First Clinical Results. J. Nucl. Med. 2018, $59 \quad$ (5), $809-814$. https://doi.org/10.2967/jnumed.117.193847.

(29) Ametamey, S. M.; Honer, M.; Schubiger, P. A. Molecular Imaging with PET. Chem. Rev. 2008, 108 (5), 1501-1516. https://doi.org/10.1021/cr0782426.

(30) Brandt, M.; Cardinale, J.; Aulsebrook, M. L.; Gasser, G.; Mindt, T. L. An Overview of PET Radiochemistry, Part 2: Radiometals. J. Nucl. Med. 2018, 59 (10), 1500-1506. https://doi.org/10.2967/jnumed.117.190801.

(31) Gallium-68 Cyclotron Production; TECDOC Series; International Atomic Energy Agency: Vienna, 2019.

(32) Price, E. W.; Orvig, C. Matching Chelators to Radiometals for Radiopharmaceuticals. Chem. Soc. Rev. 2014, 43 (1), 260-290. https://doi.org/10.1039/C3CS60304K.

(33) Spang, P.; Herrmann, C.; Roesch, F. Bifunctional Gallium-68 Chelators: Past, Present, and Future. Seminars in Nuclear 
Medicine 2016, 46 (5), 373-394. https://doi.org/10.1053/j.semnuclmed.2016.04.003.

(34) Tsionou, M. I.; Knapp, C. E.; Foley, C. A.; Munteanu, C. R.; Cakebread, A.; Imberti, C.; Eykyn, T. R.; Young, J. D.; Paterson, B. M.; Blower, P. J.; Ma, M. T. Comparison of Macrocyclic and Acyclic Chelators for Gallium-68 Radiolabelling. RSC Adv. 2017, 7 (78), 49586-49599. https://doi.org/10.1039/C7RA09076E.

(35) Malmberg, J.; Perols, A.; Varasteh, Z.; Altai, M.; Braun, A.; Sandström, M.; Garske, U.; Tolmachev, V.; Orlova, A.; Karlström, A. E. Comparative Evaluation of Synthetic AntiHER2 Affibody Molecules Site-Specifically Labelled with 111In Using N-Terminal DOTA, NOTA and NODAGA Chelators in Mice Bearing Prostate Cancer Xenografts. Eur. J. Nucl. Med. Mol. Imaging 2012, 39 (3), 481-492. https://doi.org/10.1007/s00259-0111992-9.

(36) Mitran, B.; Varasteh, Z.; Selvaraju, R. K.; Lindeberg, G.; Sörensen, J.; Larhed, M.; Tolmachev, V.; Rosenström, U.; Orlova, A. Selection of Optimal Chelator Improves the Contrast of GRPR Imaging Using Bombesin Analogue RM26. Int. J. Oncol. 2016, 48 (5), 2124-2134. https://doi.org/10.3892/ijo.2016.3429.

(37) Mitran, B.; Thisgaard, H.; Rinne, S.; Dam, J. H.; Azami, F.; Tolmachev, V.; Orlova, A.; Rosenström, U. Selection of an Optimal Macrocyclic Chelator Improves the Imaging of Prostate Cancer Using Cobalt-Labeled GRPR Antagonist RM26. Sci Rep 2019, 9 (1), 17086. https://doi.org/10.1038/s41598-019-52914-y.

(38) Rinne, S. S.; Dahlsson Leitao, C.; Gentry, J.; Mitran, B.; Abouzayed, A.; Tolmachev, V.; Ståhl, S.; Löfblom, J.; Orlova, A. Increase in Negative Charge of $68 \mathrm{Ga} /$ Chelator Complex Reduces Unspecific Hepatic Uptake but Does Not Improve Imaging Properties of HER3-Targeting Affibody Molecules. Sci Rep 2019, 9 (1), 17710. https://doi.org/10.1038/s41598-019-54149-3.

(39) Rinne, S. S.; Leitao, C. D.; Mitran, B.; Bass, T. Z.; Andersson, K. G.; Tolmachev, V.; Ståhl, S.; Löfblom, J.; Orlova, A. Optimization of HER3 Expression Imaging Using Affibody Molecules: Influence of Chelator for Labeling with Indium-111. Sci Rep 2019, 9 (1), 655. https://doi.org/10.1038/s41598-018-36827-w.

(40) Varasteh, Z.; Mitran, B.; Rosenström, U.; Velikyan, I.; Rosestedt, M.; Lindeberg, G.; Sörensen, J.; Larhed, M.; Tolmachev, V.; Orlova, A. The Effect of Macrocyclic Chelators on the Targeting Properties of the 68Ga-Labeled Gastrin Releasing Peptide Receptor Antagonist PEG2-RM26. Nucl. Med. Biol. 2015, 42 (5), 446-454. https://doi.org/10.1016/j.nucmedbio.2014.12.009.

(41) Roxin, Á.; Zhang, C.; Huh, S.; Lepage, M.; Zhang, Z.; Lin, K.-S.; Bénard, F.; Perrin, D. M. A Metal-Free DOTAConjugated ${ }^{18}$ F-Labeled Radiotracer: [ ${ }^{18}$ F]DOTA-AMBF 3 LLP2A for Imaging VLA-4 Over-Expression in Murine Melanoma with Improved Tumor Uptake and Greatly Enhanced Renal Clearance. Bioconjugate Chem. 2019, 30 (4), 1210-1219. https://doi.org/10.1021/acs.bioconjchem.9b00146.

(42) Labeeuw, B.; Gully, D.; Jeanjean, F.; Molimard, J.-C.; Boigegrain, R. Patent 5,723,483. 1998, 58.

(43) Baxendale, I. R.; Cheung, S.; Kitching, M. O.; Ley, S. V.; Shearman, J. W. The Synthesis of Neurotensin Antagonist SR 48692 for Prostate Cancer Research. Bioorg. Med. Chem. 2013, 21 (14), 4378-4387. https://doi.org/10.1016/j.bmc.2013.04.075.

(44) Kurosawa, W.; Kan, T.; Fukuyama, T. Preparation of Secondary Amines from Primary Amines via 2-Nitrobenzenesulfonamides: N-(4-Methoxybenzyl)-3-Phenylpropylamine. $\begin{array}{llll}\text { Org. Synth. } & \text { 2002, }\end{array}$ https://doi.org/10.15227/orgsyn.079.0186.
(45) Battilocchio, C.; Baxendale, I. R.; Biava, M.; Kitching, M. O.; Ley, S. V. A Flow-Based Synthesis of 2-Aminoadamantane-2-Carboxylic Acid. Org. Process Res. Dev. 2012, 16 (5), 798 810. https://doi.org/10.1021/op300084z.

(46) Battilocchio, C.; Deadman, B. J.; Nikbin, N.; Kitching, M. O.; Baxendale, I. R.; Ley, S. V. A Machine-Assisted Flow Synthesis of SR48692: A Probe for the Investigation of Neurotensin Receptor-1. Chem. Eur. J. 2013, 19 (24), 7917-7930. https://doi.org/10.1002/chem.201300696.

(47) Lang, C.; Gmeiner, P. Efficient Synthesis of Heterocyclic Neurotensin Receptor Ligands by Microwave-Assisted Aminocarbonylation. Synthesis 2013, 45, 2474-2480.

(48) Price, T. W.; Greenman, J.; Stasiuk, G. J. Current Advances in Ligand Design for Inorganic Positron Emission Tomography Tracers $68 \mathrm{Ga}, 64 \mathrm{Cu}, 89 \mathrm{Zr}$ and $44 \mathrm{Sc}$. Dalton Trans. 2016, 45 (40), 15702-15724. https://doi.org/10.1039/C5DT04706D.

(49) Vita, N.; Laurent, P.; Lefort, S.; Chalon, P.; Dumont, X.; Kaghad, M.; Gully, D.; Le Fur, G.; Ferrara, P.; Caput, D. Cloning and Expression of a Complementary DNA Encoding a High Affinity Human Neurotensin Receptor. FEBS Lett. 1993, 317 (1-2), 139-142. https://doi.org/10.1016/0014-5793(93)81509-x.

(50) Andrés, A.; Rosés, M.; Ràfols, C.; Bosch, E.; Espinosa, S.; Segarra, V.; Huerta, J. M. Setup and Validation of Shake-Flask Procedures for the Determination of Partition Coefficients (LogD) from Low Drug Amounts. Eur. J. Pharm. Sci. 2015, 76, 181-191. https://doi.org/10.1016/j.ejps.2015.05.008.

(51) Alshoukr, F.; Rosant, C.; Maes, V.; Abdelhak, J.; Raguin, O.; Burg, S.; Sarda, L.; Barbet, J.; Tourwé, D.; Pelaprat, D.; Gruaz-Guyon, A. Novel Neurotensin Analogues for Radioisotope Targeting to Neurotensin Receptor-Positive Tumors. Bioconjugate Chem. 2009, 20 (8), 1602-1610. https://doi.org/10.1021/bc900151z.

(52) Alshoukr, F.; Prignon, A.; Brans, L.; Jallane, A.; Mendes, S.; Talbot, J.-N.; Tourwé, D.; Barbet, J.; Gruaz-Guyon, A. Novel DOTA-Neurotensin Analogues for 111In Scintigraphy and 68Ga PET Imaging of Neurotensin Receptor-Positive Tumors. Bioconjugate Chem. 2011, 22 (7), 1374-1385. https://doi.org/10.1021/bc200078p.

(53) Hosseinimehr, S. J.; Tolmachev, V.; Orlova, A. Liver Uptake of Radiolabeled Targeting Proteins and Peptides: Considerations for Targeting Peptide Conjugate Design. Drug Discov. Today 2012, 17 (21-22), 1224-1232. https://doi.org/10.1016/j.drudis.2012.07.002.

(54) Hodolic, M. Safety and Tolerability of 68Ga-NT-20.3, a Radiopharmaceutical for Targeting Neurotensin Receptors, in Patients with Pancreatic Ductal Adenocarcinoma: The First inHuman Use. European Journal of Nuclear Medicine 2020. https://doi.org/10.1007/s00259-020-05045-w.

(55) Buchegger, F.; Bonvin, F.; Kosinski, M.; Schaffland, A. O.; Prior, J.; Reubi, J. C.; Bläuenstein, P.; Tourwé, D.; García Garayoa, E.; Bischof Delaloye, A. Radiolabeled Neurotensin Analog, 99mTc-NT-XI, Evaluated in Ductal Pancreatic Adenocarcinoma Patients. Journal of Nuclear Medicine 2003, 44 (10), 16491654.

(56) Fani, M.; Del Pozzo, L.; Abiraj, K.; Mansi, R.; Tamma, M. L.; Cescato, R.; Waser, B.; Weber, W. A.; Reubi, J. C.; Maecke, H. R. PET of Somatostatin Receptor-Positive Tumors Using 64Cu- and 68Ga-Somatostatin Antagonists: The Chelate Makes the Difference. J. Nucl. Med. 2011, 52 (7), 1110-1118. https://doi.org/10.2967/jnumed.111.087999. 
(57) Banerjee, S. R.; Chen, Z.; Pullambhatla, M.; Lisok, A.; Chen, J.; Mease, R. C.; Pomper, M. G. Preclinical Comparative Study of 68Ga-Labeled DOTA, NOTA, and HBED-CC Chelated Radiotracers for Targeting PSMA. Bioconjugate Chem. 2016, 27 (6), 1447-1455. https://doi.org/10.1021/acs.bioconjchem.5b00679.

(58) Roosenburg, S.; Laverman, P.; Joosten, L.; Cooper, M. S.; Kolenc-Peitl, P. K.; Foster, J. M.; Hudson, C.; Leyton, J.; Burnet, J.; Oyen, W. J. G.; Blower, P. J.; Mather, S. J.; Boerman, O. C.; Sosabowski, J. K. PET and SPECT Imaging of a Radiolabeled Minigastrin Analogue Conjugated with DOTA, NOTA, and NODAGA and Labeled with (64)Cu, (68)Ga, and (111)In. Mol. Pharm. 2014, 11 (11), 3930-3937. https://doi.org/10.1021/mp500283k.

(59) Dahlsson Leitao, C.; Rinne, S. S.; Mitran, B.; Vorobyeva, A.; Andersson, K. G.; Tolmachev, V.; Ståhl, S.; Löfblom, J.; Orlova, A. Molecular Design of HER3-Targeting Affibody Molecules: Influence of Chelator and Presence of HEHEHE-Tag on Biodistribution of 68Ga-Labeled Tracers. Int J Mol Sci 2019, 20 (5). https://doi.org/10.3390/ijms20051080.

(60) von Witting, E.; Garousi, J.; Lindbo, S.; Vorobyeva, A.; Altai, M.; Oroujeni, M.; Mitran, B.; Orlova, A.; Hober, S.; Tolmachev, V. Selection of the Optimal Macrocyclic Chelators for Labeling with 111In and 68Ga Improves Contrast of HER2 Imaging Using Engineered Scaffold Protein ADAPT6. Eur J Pharm Biopharm 2019, 140, 109-120. https://doi.org/10.1016/j.ejpb.2019.05.008.

(61) Lin, M.; Welch, M. J.; Lapi, S. E. Effects of Chelator Modifications on 68Ga-Labeled [Tyr3] Octreotide Conjugates. Mol. Imaging Biol. 2013, 15 (5), 606-613. https://doi.org/10.1007/s11307-013-0627-x.

(62) Young, J. D.; Abbate, V.; Imberti, C.; Meszaros, L. K.; Ma, M. T.; Terry, S. Y. A.; Hider, R. C.; Mullen, G. E.; Blower, P. J. 68Ga-THP-PSMA: A PET Imaging Agent for Prostate Cancer Offering Rapid, Room-Temperature, 1-Step Kit-Based Radiolabeling. J. Nucl. Med. 2017, 58 (8), 1270-1277. https://doi.org/10.2967/jnumed.117.191882.

(63) Fanelli, R.; Chastel, A.; Previti, S.; Hindié, E.; Vimont, D.; Zanotti-Fregonara, P.; Fernandez, P.; Garrigue, P.; Lamare, F.; Schollhammer, R.; Balasse, L.; Guillet, B.; Rémond, E.; Morgat, C.; Cavelier, F. Silicon-Containing Neurotensin Analogues as Radiopharmaceuticals for NTS(1)-Positive Tumors Imaging. Bioconjug Chem 2020, 31 (10), 2339-2349. https://doi.org/10.1021/acs.bioconjchem.0c00419. 


\section{TABLE OF CONTENTS GRAPHIC}

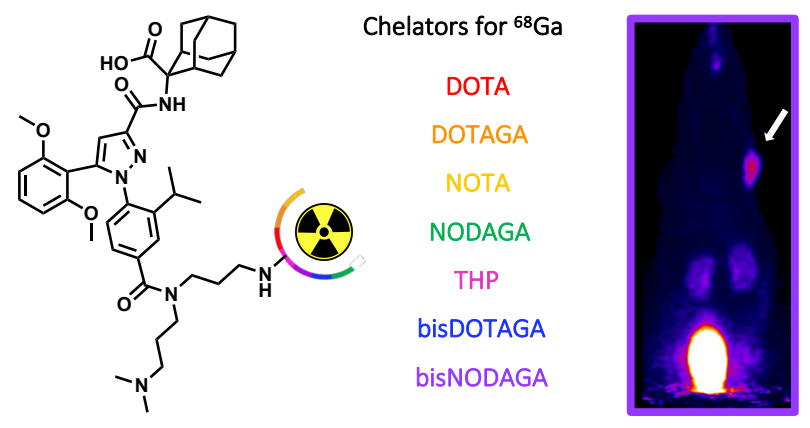

